\title{
Meeting the Demand for Local Food in West Virginia: An analysis of factors influencing producers' market participation and expansion decisions
}

\author{
Ruth Mary Oldham \\ West Virginia University
}

Follow this and additional works at: https://researchrepository.wvu.edu/etd

\author{
Recommended Citation \\ Oldham, Ruth Mary, "Meeting the Demand for Local Food in West Virginia: An analysis of factors \\ influencing producers' market participation and expansion decisions" (2013). Graduate Theses, \\ Dissertations, and Problem Reports. 631. \\ https://researchrepository.wvu.edu/etd/631
}

This Thesis is protected by copyright and/or related rights. It has been brought to you by the The Research Repository @ WVU with permission from the rights-holder(s). You are free to use this Thesis in any way that is permitted by the copyright and related rights legislation that applies to your use. For other uses you must obtain permission from the rights-holder(s) directly, unless additional rights are indicated by a Creative Commons license in the record and/ or on the work itself. This Thesis has been accepted for inclusion in WVU Graduate Theses, Dissertations, and Problem Reports collection by an authorized administrator of The Research Repository @ WVU. For more information, please contact researchrepository@mail.wvu.edu. 
Meeting the Demand for Local Food in West Virginia:

An analysis of factors influencing producers' market participation and expansion decisions

\title{
Ruth Mary Oldham
}

\author{
Thesis \\ Submitted to the \\ Davis College of Agriculture, Natural Resources and Design \\ in partial fulfillment of the requirements \\ for the degree of \\ Master of Science \\ in \\ Agricultural and Natural Resource Economics
}

Cheryl L. Brown, Ph.D.

Gerard D'Souza, Ph.D.

Thomas McConnell, M.S.

Division of Resource Management

West Virginia University

2013

Keywords: market participation, supply response, expansion intentions, local food markets, motivational factors, non-economic factors, Theory of Planned Behavior, producer decisionmaking 


\section{ABSTRACT \\ Meeting the Demand for Local Food in WV: \\ An analysis of factors influencing producers' market participation and expansion decisions \\ Ruth Mary Oldham}

Increasing demand in local food markets in WV offers a new or enhanced income generation opportunity to small producers. An ostensible gap in supply to meet this demand sparks an investigation of the factors that influence producers' decisions, as reflected by their behavior and intentions, to participate and expand in local food markets. The factors that influence both the behavior of current commercial producers and potential new entrants are identified through analysis of data collected through a survey of producers identified by field professionals. Specifically, the influence of motivational and place-based sociocultural characteristics, based on guidance from social psychology Theory of Planned Behavior, is examined within an economic framework of market participation and supply. Interest among non-commercial producers is identified and poses to be a plausible source of enhanced supply in local food markets in addition to expansion among current producers. Models of market participation behavior and supply response, using a probit model and OLS regression, indicated significant influence of motivational factors such as reasons for entering farming, influence of social context, and attitudes towards diversification of income to reduce risk. Probit model results indicate that past concerns such as time limitation and perceptions of lack of profitability limit intentions to participate in the market among current non-commercial producers, whereas past concerns about food safety and distance to market do not appear to limit those intentions. Probit model results of expansion intentions indicate the predominant influence of access to resources and farm-level factors as opposed to motivational factors on expansion. The importance of farm succession to sales volume and expansion intentions is salient. Interventions that will be successful at facilitating new entrants to market and expansion among current commercial producers must be tailored to producer values and sociocultural norms in addition to addressing resource barriers and skills. Specifically, facilitation of farm succession, implementation of marketing models that overcome distance to market and producer time and risk constraints, and education and technical assistance that is sensitive to sociocultural norms and values in general are potential leverage points. The analysis of market participation in addition to supply volume is determined to be an important aspect of analysis of supply response in local food markets in WV. 


\section{ACKNOWLEDGEMENTS}

Dr. Cheryl Brown, for her guidance, wisdom, and support through this academic process, professional path, and in other angles of life.

Dr. Gerard D'Souza, for his expertise and guidance in assuring the integrity of this work.

Tom McConnell and the Small Farm Center, for his work for local farmers and motivation and guidance to make this study relevant.

Northeast Sustainable Agriculture Research and Education (NESARE), for awarding Graduate Student Research Grant (Award Number GNE12-041) that made this project financially possible. The Appalachian Foodshed Project (Award Number: 2011-68004-30079,USDA's Agriculture, Food and Research Initiative (AFRI) grants program), for my Graduate Research Assistantship. Jennifer Williams and WVU Extension Agents, for their work for local farms, support of this study and for helping reach the population of producers.

Savanna Lyons, WV Food and Farm Coalition, for her outreach help and support.

Kelly Crane, WV Farmers Market Association, for her outreach help and support.

Kofi Nkansah and other graduate students, for their support and encouragement.

Dr. Harry Boone, for his technical expertise on survey data analysis.

WV Producers, for their daily work and willingness to undertake a long survey.

Lisa Lewis, Melanie Jimmie, Ellen Hartley-Smith, \& Anna Burdette, for their invaluable

logistical support and help throughout this process.

My husband Francisco, my family Anne, Dave, Robin, Mary, and Grandma, and dear friend Laurel Peterson, for their encouragement, support, and grounding presence throughout this process. 


\section{TABLE OF CONTENTS}

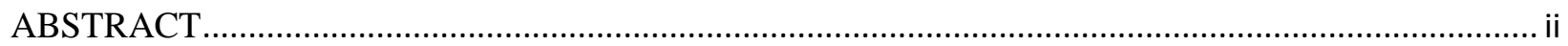

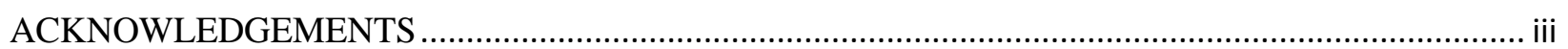

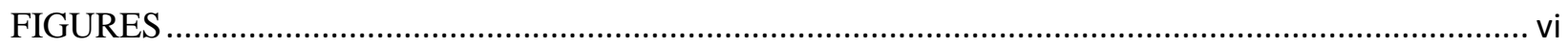

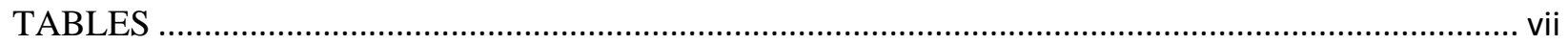

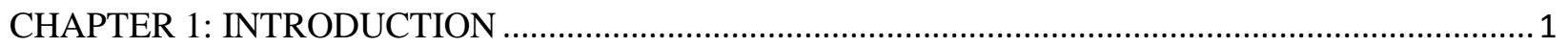

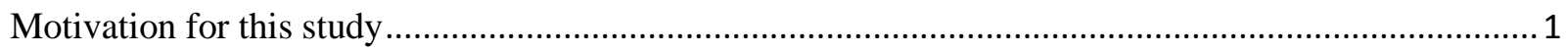

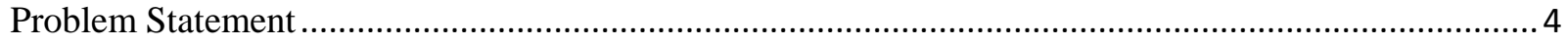

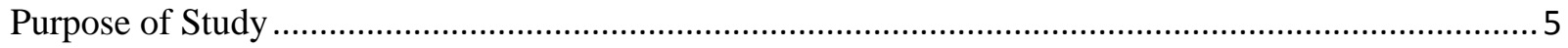

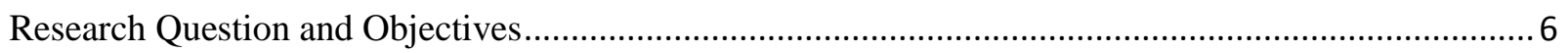

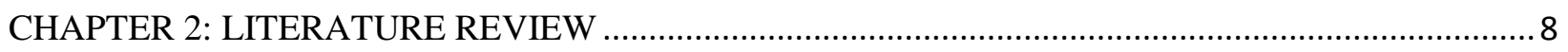

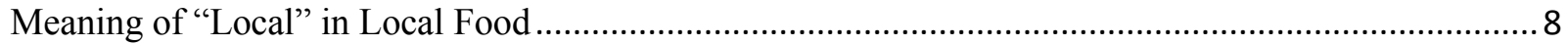

Economic factors influencing producers' behavior and intentions ....................................................... 10

Incorporation of psychological factors in economic models of producer decision-making .................. 12

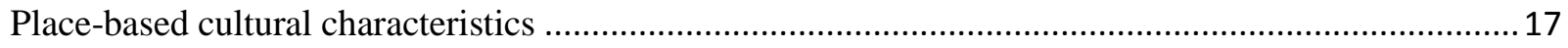

Models of Market Participation and Supply Response …............................................................... 18

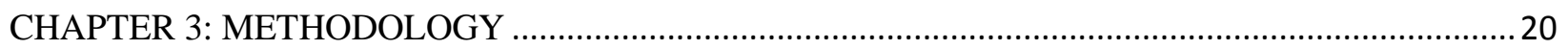

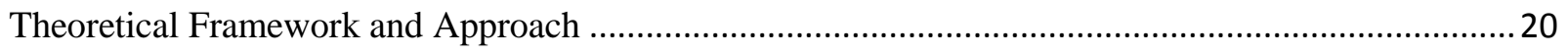

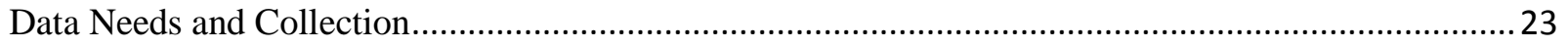

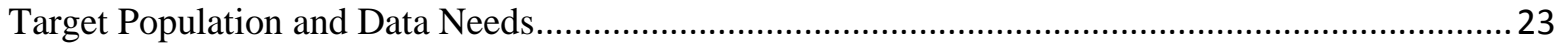

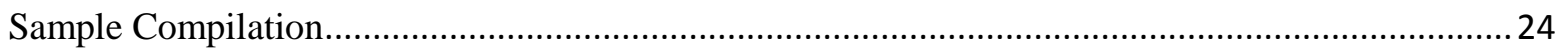

Survey Instrument: Paper and Internet Questionnaire ............................................................... 25

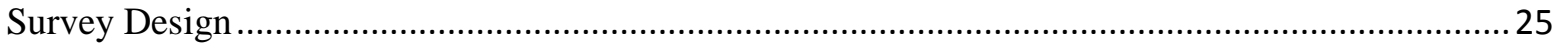

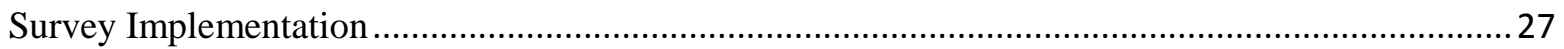

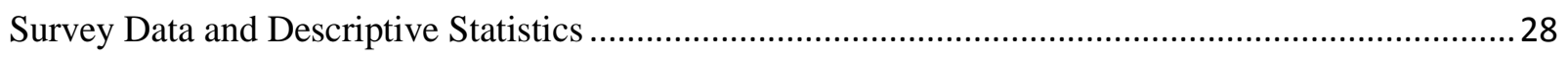

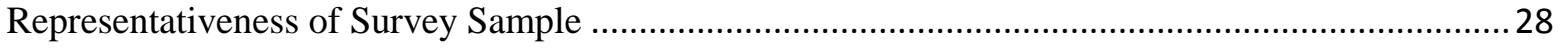

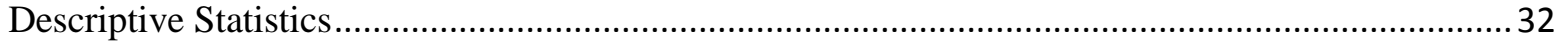

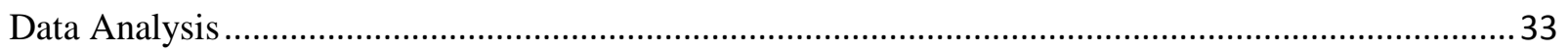

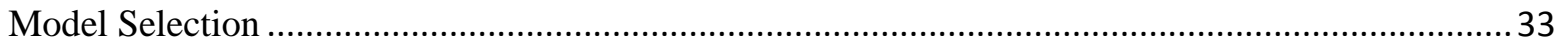

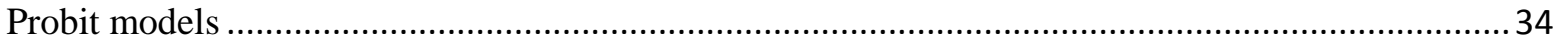

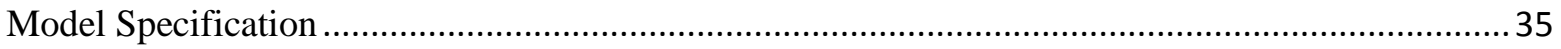




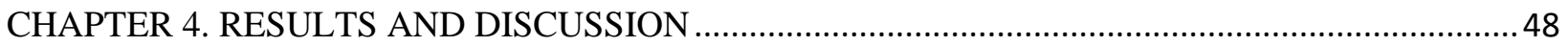

Model 1: Market Participation Decision: "To sell or not to sell” ....................................................... 48

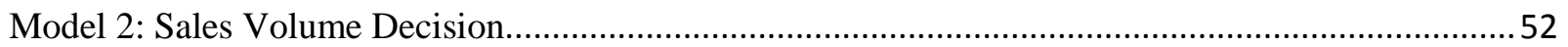

Model 3: Market Participation Intentions among Current Non-participants .......................................55

Model 4: Factors that Influence the Intention to Expand Food Production ...........................................58

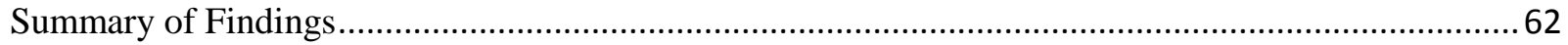

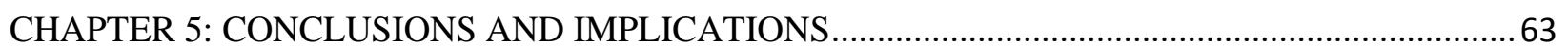

Factors that influence supply response behavior and intentions ..................................................63

Implications for Rural Development Work and Practice .............................................................6 66

Potential new entrants as a focus of rural development efforts and increase supply .......................66

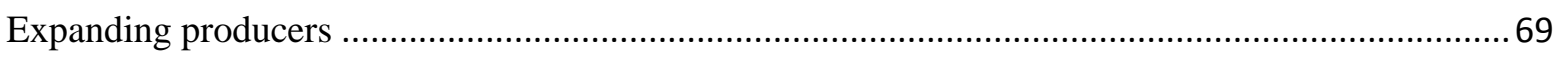

Limitations …

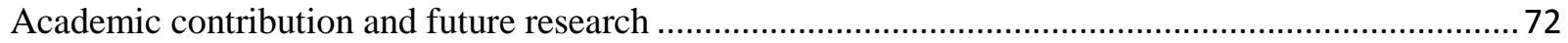

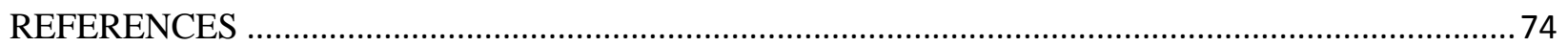

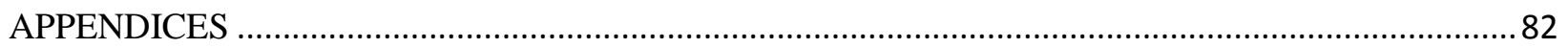

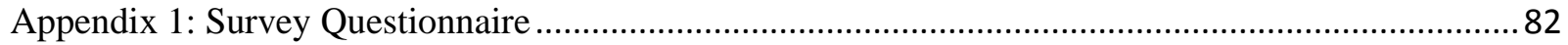

Appendix 2. Letter of request for participation in survey …........................................................... 93

Appendix 3. Descriptive Statistics for all Survey Questions .......................................................... 94

Appendix 4: Counties represented in sample ................................................................................... 173

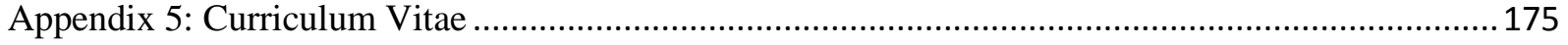




\section{FIGURES}

Figure 1: Bergevoet et al.'s (2004) representation of the Theory of Planned Behavior (Azjen,1991) with

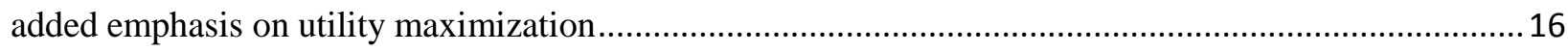

Figure 2. Conceptual framework of market participation decisions ...................................................... 21

Figure 3. Age distribution within study sample compared to WV producers ..........................................29

Figure 4. Percentage of farms in sample that reported raising different food products compared to percentage of total WV farms that raise those products ................................................................. 30

Figure 5. Gross sales distribution within survey sample compared to gross sales distribution among WV

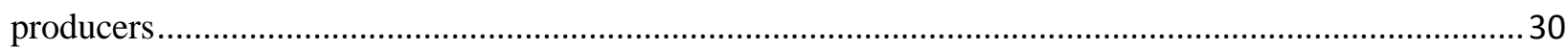




\section{TABLES}

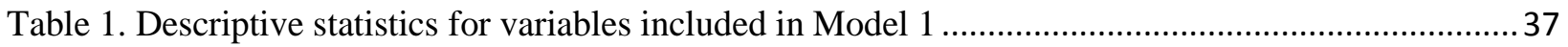

Table 2: Descriptive Statistics for Variables Included in Model 2 ........................................................ 40

Table 3. Descriptive statistics of variables included in Model 3 ............................................................ 43

Table 4: Descriptive Statistics for Variables Included in Model 4 ........................................................46

Table 5. Study Overview: Research Questions and Analytical Models .................................................. 47

Table 6. "Market Participation" Probit Model Results and Marginal Effects .......................................... 49

Table 7. Factors influencing sales volume behavior, OLS coefficients ..................................................5 53

Table 8. Factors influencing market participation intentions, Probit model coefficients and marginal

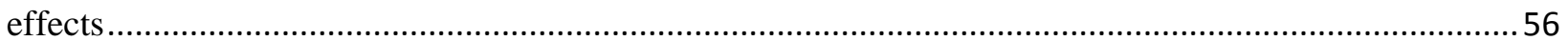

Table 9. Factors Influencing Expansion Intentions, Probit Model Coefficients and Marginal Effects ......59 Table 10. Summary of impact of variables on market participation and expansion intentions (direction of influence of significant variables) 


\section{CHAPTER 1: INTRODUCTION}

\section{Motivation for this study}

Demand for locally-produced foods ${ }^{1}$ has increased in the last few decades, offering new or increased income opportunities for small producers and spurring increased rural development work focused on local food system development. The number of farmers selling directly to consumers increased by 58\% between 1992 and 2007 nationwide, with dollar sales of directmarketed local food increasing by $215 \%$ to $\$ 1.2$ billion (USDA- NASS 2007 in Low and Vogel, 2011). West Virginia (WV) is no exception to this trend, where the number of farms marketing directly to individuals for human consumption has increased from 1434 farms in 2002 to 1990 farms in 2007, with sales levels increasing from $\$ 4,588,000$ in 2002 to $\$ 7,097,000$ in 2007 (USDA-NASS, 2007). Furthermore, the number of farmers markets has doubled in the past 10 years in WV (Hartz, et al., 2012).

In addition to increased demand on behalf of individual consumers, increasing efforts by non-profit and governmental agencies to increase access to fresh produce have also increased the demand for local food and offer new opportunities to producers. To illustrate, the WV Department of Education's Farm to School Program is enabling school districts to purchase local fresh food (WV Department of Education, 2013), and national government-sponsored WIC (Women Infants and Children) Farmers Market Nutrition Program (FMNP) and Senior Farmers Market Nutrition Program (SFMNP) encourage consumers to spend food dollars locally (Martinez, et al., 2010). These represent significant new sources of demand in both retail and wholesale markets.

\footnotetext{
${ }^{1}$ This study focuses on producers selling in WV local food markets, but who are not necessarily from WV. A more complete discussion of the meaning of "local" is found in the literature review.
} 
The opportunity to substitute an increasing portion of food consumption with food that is locally produced, as consumer preference for local food increases, has important economic implications for the state of WV, making further analysis of these markets prudent. For example, Hughes et al. (2008) illustrated that farmers markets had a net positive impact on the WV economy, increasing employment by 82 jobs (of which 43 are Full Time Equivalent (FTE) jobs) and output by $\$ 1.075$ million, even after opportunity costs were considered.

In terms of potential impact, an analysis of the economic potential of an expanded local food system conducted by Hartz et al. (2012) estimated that if WV could increase its vegetable and fruit production to meet $75 \%$ of the fresh seasonal demand for these products, an additional \$93.9 million dollars in sales could be generated, along with 1330 jobs.

In a scenario where demand is increasing, economic theory would suggest that profitmaximizing producers would increase their supply to fill this demand gap, thereby increasing their income and profits. This firm-level supply response will of course depend on many factors, the most prominent of which include price, supply chain factors such as infrastructure and distribution systems, and firm-level factors. Academic literature and practitioner efforts alike have focused on identifying and addressing the factors that influence the potential of WV farms to increase production of local food to meet demand. Hartz et al. (2012) illustrated that WV has the arable land base to be able to expand local produce production, confirming that lack of arable land is not a constraint, at least at the aggregate supply level. Several studies have contributed to an understanding of the producer and consumer-driven factors that increase producer success in local food markets (Brown, et al., 2007; 2006). These studies have helped to inform how producers and extension practitioners alike have approached increasing local market viability. In regard to addressing barriers to accessing markets, West Virginia University (WVU) Extension, 
the WV Food and Farm Coalition, and grassroots efforts have focused on increasing the capacity of farmers to take advantage of new market opportunities through investments in food safety, best practices, and season extension training and technology. Furthermore, numerous mechanisms are in place to connect producers to consumers such as the WVFarm2U website and the growing WV Farmers Market Association.

Yet despite the potential impact of local food markets and the increasing individual and program-driven consumer demand, supply seems to be lagging behind demand. Vegetable production per 1000 population in WV is the lowest of all the Central Appalachian states, at 1.2 acres/1000 (USDA-NASS, 2007), contributing to what Hartz et al. (2012) characterize as a "utilization gap" in which production falls far short of desired consumption. Furthermore, a subsequent survey of local food supply-chain opportunities and constraints found that lack of supply was a prevailing roadblock to further local food supply chain development (Peters, et al., 2012). This display of local shortage leads one to inquire: what might be limiting supply response among WV producers?

The extent to which different factors will influence producer response varies also by place. An analysis of the agricultural landscape in WV may reveal some new factors to consider as possible explanation of the rate or nature of producer supply response. Considering that $80 \%$ of WV farms gross less than $\$ 10,000$ annually and 64\% of farms reported net losses in 2007 (USDA-NASS Census of Agriculture, 2007), one might question the extent to which farm income is important to WV farmers, or rather, question their motivation for farming. The 2007 US Census of Agriculture offers a glimpse into types of small family farms in WV: $21 \%$ are limited resource farms, $27 \%$ are retirement farms, $39 \%$ are residential lifestyle farms, $10 \%$ are 
farming occupation/lower sales farms, and less than $1 \%$ are farming occupation/higher sale farms.

Hartz et al. (2012) assert that increased supply of local food would be the result of either 1) an increase in the number of producers supplying local food to markets (i.e. new producers entering markets) or 2) in increase in production and supply to local markets by current producers (i.e. expansion), or a combination of the two. This assertion has implications for economic development and agricultural extension work. Which local producers are interested in scaling up production for local markets? Are there local producers who are not selling in local markets currently? Why or why not? Who is most likely to scale up? What kinds of interventions would be most effective in targeting them? Answering these questions requires first building on research that identifies the characteristics of producers in WV's local food system to better understand what motivates them to make the decisions they make or could make in local markets.

\section{Problem Statement}

As demand for locally-produced foods increases in WV, extension educators and other community development practitioners are eager to enable producers to take advantage of new opportunities for income generation and to increase supply. In order to assist producers to increase their supply, it is first necessary to understand which factors motivate their supply response in order to identify leverage points and target producers that have a greater propensity to increase their supply. While research on producer decision-making has been focused mainly on volume in the US, exploration of the market entry or participation decision is scarce. Understanding what makes a producer more likely to commercialize their produce in the first place, rather than produce it on a hobby basis or for personal use, has implications for local food 
supply growth in WV, where farmers market managers have reported engaging in outreach efforts to increase vendor participation among currently non-commercial producers. For example, Schupp et al. (2012) assert that the transition of "self-provisioning" producers to commercial production could be a potential source of increased local food supply. Long's (2011) study of self-provisioning producers in WV revealed that some producers that selfprovision also sell their product and that these producers differ in characteristics and motivation from those self-provisioners that only produce for their own consumption. Understanding this "market orientation," in addition to the decision about supply volume, is critical to gaining a full picture of supply response in the given context. Furthermore, while the incorporation of psychological models in behavioral economics within the last decade has explained the general behavior of farmers and has improved the explanatory power of economic models, the incorporation of psychological constructs to models of specific decisions that farmers make is scarce in the literature (Hansson, et al. 2012). Specifically, while economic literature offers insight into farm-level factors that influence Appalachian producers, consideration of the influence of cultural and motivational characteristics on their decisions has been primarily qualitative in nature.

\section{Purpose of Study}

This study seeks to identify the factors that impact producers' supply behavior and intentions regarding market ${ }^{2}$ entry and sales volume to enhance understanding of WV producers' current and potential supply response in local food markets. By examining the differences in producers who are market-oriented (inclined to commercialize their product) and those that are

\footnotetext{
${ }^{2}$ This study refers to market participation and entry with regard to generic markets as being a forum where a producer would commercialize their product rather than use it for home consumption. The use of the word market should not be confused with a specific market such as farmers markets.
} 
not (produce food but not for sale) this study will identify whether or not market entry is a relevant aspect to understand supply response in local markets. Offering information on the motivational and attitudinal characteristics of producers as they relate to both the market entry and supply volume decisions in a US context complements existing literature on producer decision making that has hitherto focused on farm-level factors primarily related to the volume decision. This study aims to identify factors that may explain the supply lag in WV that are unique to the place-based Appalachian context. This information on the factors that influence supply response among WV producers will be useful to field professionals who seek to enhance participation and expansion in local food markets among area producers by enabling them to design or identify interventions and trainings, outreach strategies, or even aggregation and distribution models that could target certain groups of producers. In addition to this practical application, this study aims to build on small farm market participation and supply response

literature by examining the factors that influence market entry along with the influence of noneconomic factors using social psychology’s Theory of Planned Behavior.

\section{Research Question and Objectives}

\section{Research Question}

What factors influence the supply response behavior and intentions of producers in WV local food markets?

\section{Objectives}

Objective 1. Identify the factors that influence market participation behavior in WV local food markets

Objective 2. Examine the factors that influence commercial producers' sales volume behavior 
Objective 3. Explore the factors that influence the market participation intentions of noncommercial potential new entrants

Objective 4. Identify the factors that influence expansion intentions of market-oriented producers 


\section{CHAPTER 2: LITERATURE REVIEW}

\section{Meaning of "Local" in Local Food}

Given that this study explores the potential of producers to meet the demand for local food in WV, it is necessary to explain what is meant by local. The increased demand for "local" food has been accompanied by over a decade's worth of research examining exactly what "local" means and to whom. There is no agreed-upon definition of local food (Martinez, et al. 2010), but there has been some agreement on the elements that compose the multitude of definitions. Such definitions have been based on a combination of the following elements: geographic proximity, social values related to producer-consumer interaction, preservation of the characteristics of the product, producer, and place, and supply chain characteristics.

While location or geographic proximity is important to most attempts to define "local" food, the distance and criteria vary and appear to be largely relative to the characteristics of the region, market, and populations of a given place (Martinez, et al. 2010). Some definitions are related to miles from production to consumption. For instance, Smith and MacKinnon (2007) define local as 100 miles from the point of production to consumption, which is also the basis for the term "locavore" (Martinez et al., 2010). However, some studies of consumer perception have shown that many consumers do not agree with this definition (Durham et al., 2009 in Martinez et al. 2010) or that they define local as within a state (Hu et al., 2009 in Martinez, et al. 2010) or an even smaller geographic range such as less than 50 miles (Adams and Adams 2008; Hu et al. 2010 in Meas, et al. 2013). Hu and Woods (2012) found that consumers were willing to pay more for products labeled with a state brand such as "Kentucky Proud" as well as for products labeled as being from a sub-state region or multi-state region. The USDA's Food Conservation 
and Energy Act of 2008 defined local products as those consumed within 400 miles of where they are produced or within the state where they are produced (Martinez, et al. 2010).

Perceptions of distance characterization of "local" differ from region to region depending on population density and accessibility of supply (Martinez, et al 2010; Ilbery and Maye, 2006) and in some cases distance may refer to direct consumer-producer interaction and may not be defined by geographical proximity (Selfa et al., 2005). The concept of local food goes beyond distance to encompass social factors related to the connection between producer and consumer (Hinrichs, 2000; Sage 2003 in Martinez et al 2010; Dunne et al, 2010) and the preservation of identity or story related to both by whom the product was produced and how it was produced (Thompson et al, 2008). Many authors define local as being very much defined 'in the eyes of the beholder' based on place-based social, environmental, and political factors (Feagan, 2007) and differing concepts of sense of place and community (Ostrom, 2006).

The concept of shorter supply chains also appears to be part of the perception of "local" where the connection between producer and consumer is either direct or maintained through provision of information to consumers. Such short supply chains and their retention of the values attributed to local food may be easily identified by marketing outlets such as farmers markets, but in supply chains with intermediaries this underlying demanded value may be retained based on location of supply chain components such as production and processing and by transparent transfer of this information to consumers (Hand and Martinez, 2010). One confounding issue in the effort to define local is whether products that are produced elsewhere but processed locally are local, or conversely, whether products that are produced locally and processed elsewhere are local (Ostrom, 2006; Martinez, et al. 2010). Dunne et al. (2010) found that food retailers considered food that was processed locally to be local because it was supporting the local 
economy. In their recent study assessing local food marketing channels, Low and Vogel (2011) examine direct-to-consumer (farmers market, roadside stand, etc.) and intermediated sales (farmer to grocery or restaurant), which they consider to be both undebatable "local" food marketing channels used by farmers that avoid definitional issues related to geography or other factors.

The scope of "local" in this study is at a state-level, where potential for expanded supply in markets within WV is examined. The study sample was derived by identifying producers that are or could potentially sell in local food markets in WV, as defined by field workers and service providers that work with such producers and markets. This group is not limited to producers that are located in $\mathrm{WV}$, but instead encompasses producers that may come across state boundaries to sell in WV markets.

\section{Economic factors influencing producers' behavior and intentions}

Since World War II, the US agricultural horizon was characterized by a decline in the number of farms and increase in size of farms as the US food system shifted to reliance on national and global food sources and away from local sources. However, changes in consumer preferences in the last few decades have resulted in an increasing "relocalization" of the food system and have offered opportunities for small farms (Martinez, et al., 2010).

As new market opportunities arise, the extent to which producers will increase supply depends on a host of supply and demand-driven factors. They may face barriers that limit their ability to access markets or fully realize their potential. Factors known to be related to local food sales include climate, topography, fruit and vegetable production, access to transportation and infrastructure, proximity to neighboring farms that sell local food and proximity to farmers 
markets (Low and Vogel, 2011). Farm sales in local food channels are also influenced by their production enterprises. Vegetable and fruit and nut farms are eight times more likely to sell in local markets than other farms (Low and Vogel, 2011). Common barriers to market entry and expansion are related to difficulty in meeting volume or quality requirements in intermediated markets, costs of direct marketing and processing in terms of time and labor, logistical barriers, lack of aggregation and distribution infrastructure, obstacles related to regulations, traceability, and educational barriers (Martinez, et al., 2010).

Factors associated with increased direct market sales in WV include higher median housing value in the area, higher population density, greater fruit and vegetable diversity of production, closer proximity to Washington, D.C., younger population base, and a greater number of direct market farms (Brown, et al., 2006). In a study examining what characteristics and factors influence producer success in farmers markets, Brown et al. (2007) found that producers who bargained, implemented cost-plus pricing, sold at markets outside of WV, provided print materials, had a wider diversity of products, traveled further to markets, participated for more weeks at the market, and were full-time farmers had higher sales.

Farm type has been shown to correlate with producer characteristics and decisions (Detre, et al., 2011; Gillespie and Mishra, 2011). Farms that are close in proximity to other farmers that sell in local food channels are more likely to sell in local food markets, reflecting what is known as neighborhood effects (Low and Vogel, 2011). Some studies have examined the relationship of labor to land used (which indicates production scale) by including explanatory variables related to existing labor availability such as household labor used and non-household members working on the farm (Bartolini, et al., 2011). 


\section{Incorporation of psychological factors in economic models of producer decision- making}

The unique cultural characteristics of rural Appalachia raise questions about how WV producers make decisions. According to neoclassical economic theory which conceives of producers as profit-maximizing decision-makers, producers will respond to increased prices caused by increased demand to supply the level of product that maximizes their profits. However, a large body of research has illustrated that producers do not always exhibit profitmaximizing behavior and that their decisions may be more accurately understood through a utility maximization framework in which the farmer seeks to balance profit maximization goals with other non-economic goals when making farm development decisions (Garforth and Rehman, 2005). Edwards-Jones (2006) discusses how economic models have based farmer decision making in the profit maximizing framework because profit is used as a substitute for utility because utility is difficult to measure. He asserts that when profit motivation is the underlying goal, models assuming profit maximization are effective and highly predictive, but that as the importance of profit declines, these models are no longer as accurate in predicting behavior. The consideration of psychological factors and utility beyond profit maximization is particularly important when it comes to how farmers will react to policy considering it is often related to non-economic issues (Edwards-Jones, 2006).

Gasson (1973) was one of the first economists to pioneer exploration of the noneconomic factors that influence farmer decision-making and is known for her articulation of four main values that influence farmers in their utility-maximizing decisions: instrumental (economic), intrinsic, expressive, and social values. Instrumental values are related to income generation motivation. Intrinsic values might be observed as importance of farming as a lifestyle. Expressive values are related to producer self-image and creativity related to their activities and 
role. Social values relate to the value that the producer associates with her/his social context and activities. Subsequent research on farmer decision making has illustrated that producers' decisions are based on a complex set of non-economic (as well as economic) factors, including farm goals, motivation for entering farming, farmer life-phase, and farm-level characteristics.

For instance, Lahtinen and Vare (2011) found that strategic objectives related to social and environmental responsibility, work satisfaction, and economic objectives, as well as farm development plans related to diversifying, refocusing, and increasing capacity were different for farmers grouped as early, middle, and late "phase" farmers according to farm and farmer characteristics. Bessant (2000) also established categories for Canadian part-time farmers based on their life phase and goals. O'Donnell et al. (2011) classified dairy producers according to their expansion intentions (expanding, static, exit, contracting) and examined the relationship of these expansion intentions with perceived limitations and farm and farmer characteristics. They found that while significance of perceived limiting factors varied among expansion categories, overall farm characteristics such as succession plan, size, and age were the most significant factors affecting future expansion plans. Walters (1997) used factor analysis to classify farmers according to their own visions of a successful farmer to better understand their goals and the extent to which they might respond to different types of targeted media and extension publications.

Berkhout et al. (2010) illustrated that models including behavioral variables related to goals and preferences in addition to farmer characteristics better explained efficiency levels of smallholder farmers in Nigeria than models including farmer characteristics alone. Farmer motivation other than profit maximization, related to reasons for entering farming and off-farm work, was found to have a significant influence on farm production enterprise decisions in a 
study using US Department of Agriculture's (USDA) national Agricultural Resource Management Survey (ARMS) data (Gillespie and Mishra, 2011). Other non-economic factors having a significant impact on producer decisions have been illustrated: traditions and beliefs (Jari and Fraser, 2009), and diverse socioeconomic characteristics (Higuchi, et al., 2012).

Research interested in explaining producers' behavior through the incorporation of psychological factors has naturally sought theoretical support from the field of social psychology. A specific application of interest to this study is the Theory of Planned Behavior (Azjen, 1991), as a means for understanding and organizing the factors that influence human behavior. The Theory of Planned Behavior holds that people's intentions to behave in a certain way are accurate predictors of how they will in fact behave (Azjen, 1991). Intentions are influenced by attitudes, subjective norms, and perceived behavioral control. Attitudes may be understood as the individual's negative or positive perceptions about a given behavior. Subjective norms refer to how the individual perceives social pressures to engage in the given behavior (Azjen,1991), particularly among those most important to her/him (Fielding, et al.2008). Perceived behavioral control refers to the extent to which the individual believes s/he has control over the ability to engage in the behavior. Past behavior is an element that was added to the model as a predictor of future behavior (Azjen, 1991). Persons who think positively about engaging in a behavior (attitude), believe that people that are important to them think favorably about the behavior, and believe that they are capable of engaging in the behavior, will in fact engage in such behavior (Fielding, et al., 2008). Azjen (1991) explains that whether or not an individual will act on her/his intentions depends not only on intentions (as influenced by attitudes, subjective norms, and perceived behavioral control) but also non-motivational factors related to her/his actual control over the behavior. Such factors may include the availability of 
opportunities and resources such as skills, time, money, and the help of others (Azjen, 1991). The premise of the theory is that if the person has the intention to carry out a behavior and has the resources to do so, s/he most likely will behave in that way. The psychological constructs of the Theory of Planned Behavior are considered to be latent, non-observable constructs, but it is possible to measure them via observable indicators (Hansson, et al., 2012).

Bergevoet et al. (2004) highlights the contribution of Van der Pligt et al. (1995) to the theory in terms of including barriers and skills as a mediating force reflecting actual control between intentions and behaviors. This contribution would seem to be particularly important in terms of the application of this theory in the economic context, where barriers and skills are critical elements of economic theory. Gasson (1973) called for the incorporation of motivational factors with information available on constraints and resources to better model producers' economic behavior. She emphasized the short-comings of economic theory that "treats motivation as a parameter, explaining variation in economic behavior in terms of availability of resources" (Gasson, 1973, 521). She defines goals as "ends or states in which the individual desires to be or things he wishes to accomplish" and values as "a more permanent property of the individual, less liable to change with time and consequences" than goals (Gasson, 1973, 524). Within the context of the Theory of Planned Behavior, Gasson's values would be underlying factors influencing attitudes and subjective norms. Goals would be related to intentions. She explains that "values are cultural products...not inborn but learned mainly in childhood through social interaction" (Gasson, 1973, 524). According to Gasson, values cannot be observed but can be explored through observation of behavior or responses given verbally. Gasson suggests that the complex nature of values can mean that what an individual expresses may be more reflective of what is socially acceptable to express. Figure 1 illustrates Bergevoet et al.'s (2004) 
representation of Azjen's (1991) Theory of Planned Behavior with the included contribution by Van der Pligt and de Vries (1995).

Figure 1: Bergevoet et al.'s (2004) representation of the Theory of Planned Behavior (Azjen, 1991) with added emphasis on utility maximization

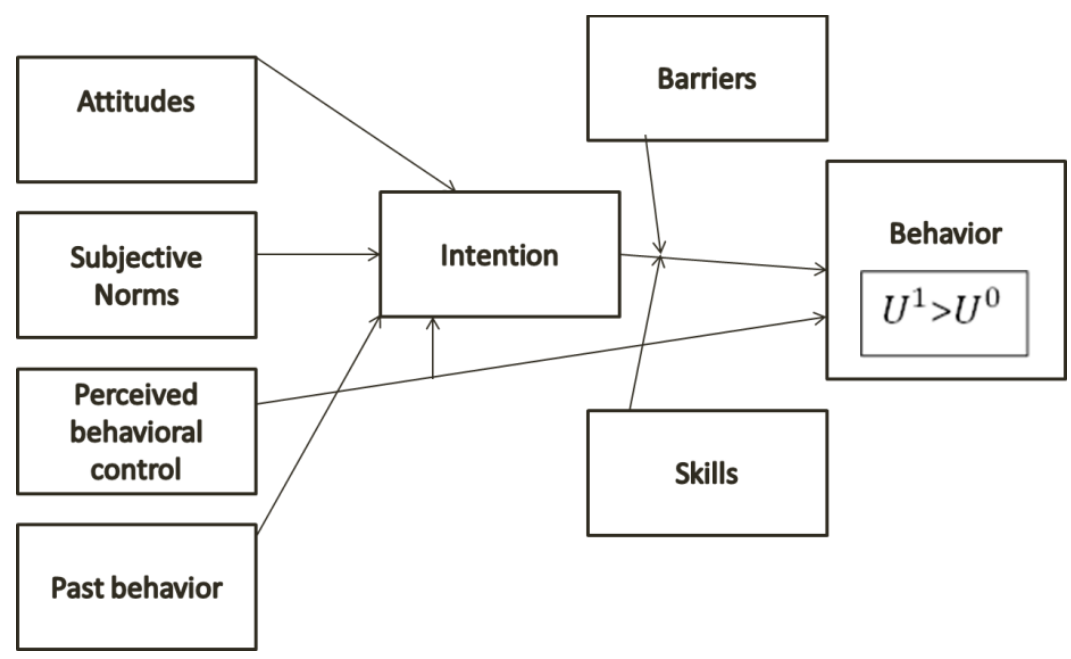

Of interest to this study, the Theory of Planned Behavior has been applied to understand entrepreneurial intentions and behavior (Traikova et al., 2012), adoption of sustainable agricultural practices (Fielding et al., 2008), and diversification into off-farm enterprises (Hansson et al., 2012). In their study applying the Theory of Planned Behavior to understand the entrepreneurial intentions of farmers to start-up non-farm business ventures, Traikova et al. (2012) found that having a positive attitude towards the idea of a start-up business, perception of a corrupt business environment, and higher capital endowment increased the likelihood of entrepreneurship. They assert that the Theory of Planned Behavior is a valuable framework for understanding such behavior because it organizes a host of factors that must be considered in relation to their impact on entrepreneurship into three predictors (Traikova et al., 2012). Fielding et al. (2008) found that group social identity related to group norms and intergroup perceptions, as well as the normal components of the Theory of Planned Behavior such as past behavior, attitudes, and perceived behavioral control significantly predicted intentions to adopt sustainable 
agricultural practices, and that intentions were significant predictive factors of behavior that producers reported. Bergevoet et al. (2004) found that diversification (in terms of having offfarm work to reduce risk) was negatively correlated with farm size among dairy farmers, as illustrated by milk quotas. They found that farm size could be primarily explained by economic or instrumental goals, rather than by goals related to social, expressive, or intrinsic values.

\section{Place-based cultural characteristics}

Ethnographic research has highlighted place-based characteristics of WV producers and factors that influence their food production decisions that have yet to be explored by quantitative research. For example, Long (2011) identified key cultural and political motivational attributes that influenced self-provisioning and commercial food production motivation of $\mathrm{WV}$ producers, identifying four distinct groups of producers: "the movement", the "back-to-the-landers", "the hobbyists", and the "American farmers". Lalone (2010) examined the ways in which producers in the Appalachian region have traditionally diversified their risk and income streams as part of their complex "rural livelihood strategies", which they have evolved to adapt to changing conditions in economic patterns and the agricultural landscape. Such strategies include reciprocity, pooling, and diversification. Reciprocity may be understood as sharing and trading of resources among friends, family, and neighbors. Pooling refers to combination of income from multiple persons. Diversification refers to strategies that the family employs to reduce risk such as having different sources of income like an off-farm job or multiple farm enterprises. The prevalence of a culture focused largely on risk minimization and diversification of economic activities may influence the extent to which WV farmers are likely to change their farm operations to pursue perceived but uncertain opportunities in the local food system. 


\section{Models of Market Participation and Supply Response}

In the agricultural economics literature, the decision to participate in markets is often considered to be an adoption decision. While many studies have examined the decision to produce and the decision about how much to produce as simultaneous decisions (Heckman, 1979), other economists have examined the decisions as two sequential decisions that could be influenced differently by different explanatory variables. The theoretical treatment of this decision process as a sequential decision has empirical implications as well, leading to the restructuring of corresponding econometric models. For example, Cragg (1971) reformulated the traditional Tobit model to allow for the sequential modeling of the participation and volume decisions as separate decisions impacted by separate explanatory variables. This has allowed for the identification of factors that influence the participation decision and volume decision distinctly.

The market participation literature focused in developing countries is of particular insight and application for this study. Whereas much of the market participation literature in the US is focused on sales levels or market diversification or transition, the literature focused in developing countries provides insight on market entry as well, exploring the transition of producers from subsistence production to commercial production or, alternatively, from traditional markets to alternative new markets. Areas of focus have included transition from traditional coffee markets to certified coffee markets in Uganda (Angula, 2010); decision of Peruvian farmers to join a marketing organization vs. market through intermediaries (Higuchi et al., 2012); the decision to commercialize products (Jari et al., 2009); and how producer goals influence efficiency in Nigeria (Berkhout et al., 2010). Of this literature, of particular use is the study done by Jari et al. (2009), examining the decision of subsistence producers to 
commercialize their products. While it may not be completely accurate to define non-commercial WV food producers as "subsistence" producers, it is useful to draw on the distinction between those commercializing and those producing agricultural products for other uses, whether for subsistence or other reasons. 


\section{CHAPTER 3: METHODOLOGY}

\section{Theoretical Framework and Approach}

This study proposes to approach the farmer's decision as a sequential decision in order to examine whether different factors have different impacts on the first decision and the second decision. The extent to which these factors do have different impacts could have important implications for development policy that attempts to increase market participation (new entrants) versus increase success (expansion) for producers that have obviously already chosen a given market. The relevance of this framework and an exploration of place-based variables that best explain WV producers' decisions are examined.

Figure 2 illustrates this conceptualization of producers' supply response decision as a two-step sequential decision process. In this framework, a producer is assumed to first make a "market participation" decision in which s/he decides whether or not to enter the market. In this application this refers to whether or not s/he chooses to sell her/his food products. This decision is assumed to be influenced by a range of factors. The producer who decides to participate in the market then makes another decision about how much s/he will supply, which is often modeled using sales levels. The premise of sequential decision making models of market participation and supply response is that the factors that influence a producer's discrete decision to participate could be different than those that influence her/his supply levels (Angula, 2010).

This premise has direct application to the research questions posed. It is assumed that understanding the decision of producers to participate in the market is a reasonable way to analyze which factors are likely to influence new entrants to the market. What is learned about the difference between those that are participating in markets and those who are not could yield insight into what characteristics or factors increase the likelihood of a producer to enter markets. 
In practice, this information can then we utilized by field professionals that seek to develop strategies to increase market participation and encourage new entrants. Furthermore, by understanding what factors influence the volume decision of producers that currently produce (those that have already made the market participation decision) it is possible to provide information that can assist field professionals to aid current producers to expand their operations and hence increase supply.

Figure 2. Conceptual framework of market participation decisions

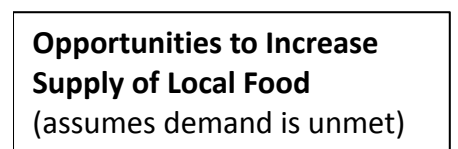

Opportunities to Increase

(assumes demand is unmet)

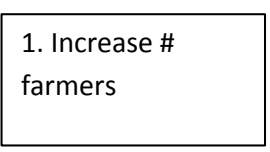

1. Increase \#

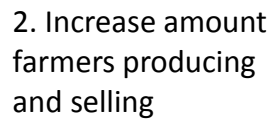

2. Increase amount farmers producing

and selling

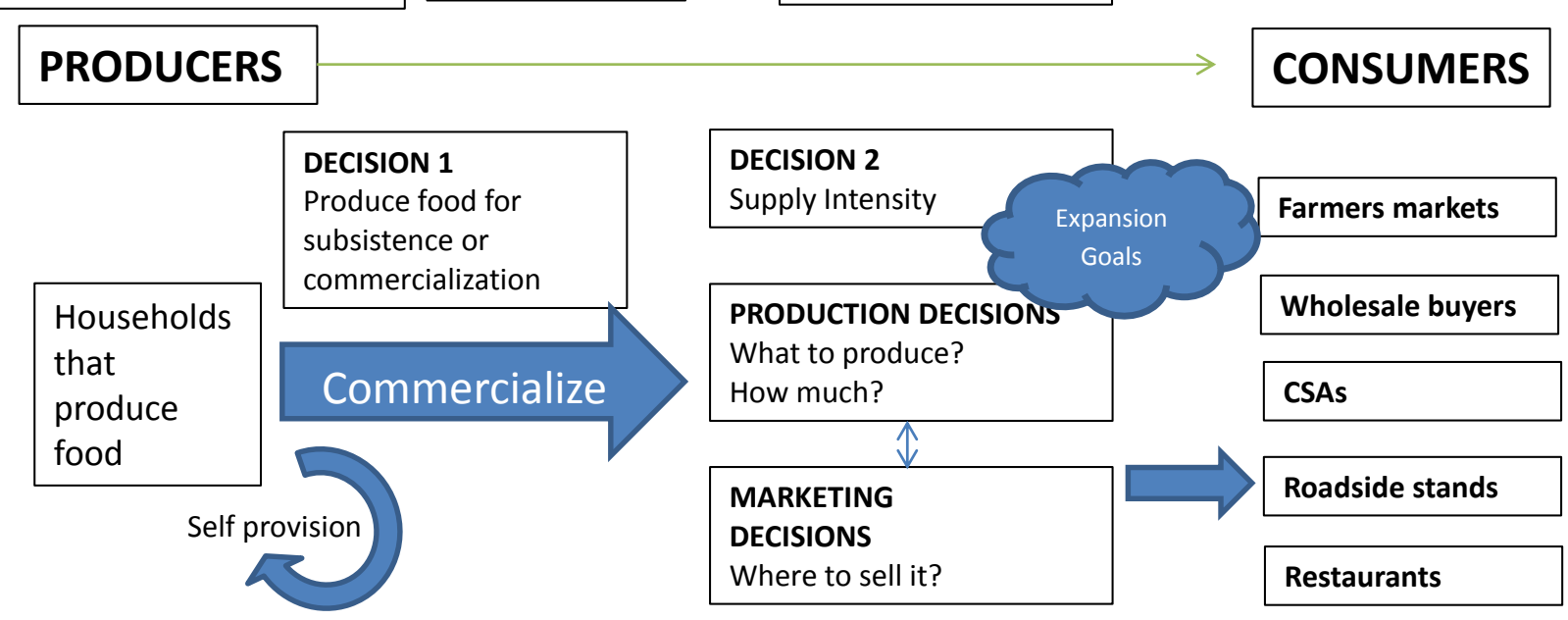

The present study draws on the Theory of Planned Behavior to understand the factors that influence the following aspects of supply behavior according to the sequential decision-making framework. The market participation decision is analyzed by examining behavior that has already occurred (whether or not a producer sold product in 2012). According to the Theory of Planned Behavior, behavior is a result of intentions which are fulfilled or not due to the influence of barriers and skills. Economic literature has provided great insight on the barriers and skills (farm level factors and producer characteristics) that may mediate intentions. If it is assumed that producers are profit-maximizing beings, these are the only factors we must consider because one 
must assume that the producer's intention is to sell her/his product. Within this line of thinking, a) only producers that are in the market are of concern, and b) providing solutions to barriers and enhancing skills are the only means to increase a producer's success in the market.

To a certain degree it is possible to understand producers' behavior by what similar producers currently do. This is the basis for modeling decision 1 and 2. However, the Theory of Planned Behavior holds that intentions are a good predictor of future behavior. Working backwards, according to the Theory of Planned Behavior, if one wants to understand the behavior that is likely to occur, it is first necessary to understand intentions. Economic studies have explored intentions using stated choice models, which are considered to be generally representative of the actual actions and preferences of respondents (Bartolini et al., 2011), keeping in line with the Theory of Planned Behavior. By relaxing the profit maximizing assumption, it is possible to explore a whole host of non-economic factors that could influence producers to behave the way they do. This relaxation then allows us to consider the impact that varying attitudes, aspects of perceived behavioral control, and subjective norms have on the person. If it is the case that WV producers are risk averse and slow to take advantage of new opportunities, it is beneficial to explore future goals and intentions in order to understand the trajectory of local food supply. This could indicate a change in the supply response. For example, if factors that significantly influence current sales levels are different than those that influence expansion intentions, the type of interventions that address each group could be adjusted accordingly.

In the present study the following assumptions are made based on the theoretical framework: 
A) Producers are not necessarily motivated by profit-maximizing intentions.

B) Non-economic constructs can significantly influence intentions and therefore behavior.

C) Understanding these factors is necessary to understanding the decisions of WV farmers and the potential for local food system growth.

\section{Data Needs and Collection}

\section{Target Population and Data Needs}

Data related to producer goals and attitudes for WV producers were not available from secondary data sources such as the US Census of Agriculture. Furthermore, such data sources only include information for producers who sold product. To understand market participation by understanding the difference between characteristics of producers who sell and do not sell, data about both groups were needed. It was therefore necessary to implement a survey to collect primary data. The target survey population is defined as those producers who are currently selling in local food markets and those who could potentially enter those markets in the next two years. The former category has received more attention in the literature and is more clearly defined. To define "those who could potentially enter markets" a population slightly beyond the boundaries of the market was targeted-producers who are in communication with field professionals such as WVU Extension Agents and farmers market managers. It was assumed that this group of people producing food would be the most likely of the population not currently selling in local markets to decide to participate in markets. In other words, this study assumes that these would be the producers "most likely to be new market entrants". 


\section{Sample Compilation}

To compile a list of contact information for the survey population of "local food producers" (that included subpopulations of producers who sell and who do not sell), the help of field professionals was needed. Specifically, collaboration with West Virginia University (WVU) Agricultural and Natural Resources Extension, the WV Small Farm Center, and the WV Farmers Market Association was sought. WVU Extension encouraged Extension agents to collaborate on this study, and the WV Farmers Market Association facilitated time during a meeting in order to pitch the idea to a group of market managers. The WV Food and Farm Coalition also collaborated with contacts and other support. The WVU Small Farm Center provided a list of producer contact information.

In late fall of 2012, over fifty WVU Agricultural Extension Agents and Farmers Market Managers were contacted and asked to provide representative lists of producers in their area who currently market their products or who could market in the future. Lists were received from over thirty agents and five market managers. Three market managers said that they did not feel comfortable sharing contact information without producers' permission, but offered to administer the survey themselves. Between lists provided by Extension agents and specialists and the WV Small Farm Center list, the final list included 1705 producers from a total of 76 counties: 53 in West Virginia, 8 in Pennsylvania, 4 in Maryland, 7 in Ohio, 3 in Virginia, and 1 in Tennessee. The population did not include anyone from Mingo or McDowell counties in West Virginia (Appendix 3). The study was not limited to producers from WV because the study is focused on the factors that influence supply in WV local food markets, which may encompass producers from surrounding states. To draw the line at state boundaries would be an inaccurate 
limitation of the local food system. In order to avoid sample selection bias, the entire population of these producers who had been identified by field professionals was surveyed.

\section{Survey Instrument: Paper and Internet Questionnaire}

In order to conduct the survey of producers, a questionnaire that contained close-ended and open-ended questions regarding areas of interest was designed. Questionnaire content was based on the literature on relevant farm-level characteristics and potential barriers, and motivational characteristics. Construction of some questions was modeled on the literature of survey work related to producer motivations conducted by Garforth and Rehman (2005). Many of the phrases used to illicit attitudes were crafted based on previous surveys implemented by Bergevoet et al. (2004) and O’Donnell et al. (2011), as they had been vetted to capture psychological constructs that were of interest in this study. Content was enhanced and adapted to local context and area of inquiry through detailed conversations with WV Small Farm Center faculty and field professionals such as WVU Extension Agents. The questionnaire was pretested through a focus group of four producers who completed the survey questionnaire and discussed feedback and improvements with the researcher. They were paid with a $\$ 50$ gift card for their time and input, which was used to improve the final survey questionnaire (Appendix 1).

To ensure the reliability of the survey instrument in terms of internal consistency of responses to questions, a statistical alpha scale test, Cronbach's Alpha, was run on the sample population data. A resulting value of 0.83 indicated "exemplary" reliability of the instrument (Robinson, Shaver, and Wrightsman, 1991).

\section{Survey Design}

Guidance from Dillman's (2000) Tailored Design Method (TDM) was followed to design the survey and its implementation, with slight modification to suit budgetary and logistical 
constraints. The TDM stresses the importance of repeated but distinct contact with participants in order to improve response rates. This is achieved through four steps of precisely timed contact: an initial letter and survey questionnaire, a postcard thank you or reminder two weeks later, another letter and questionnaire to those who still have not responded two weeks after the postcard, and a final contact effort that is often through a different medium (i.e. phone vs. mail), if appropriate, four weeks after the second letter (Dillman, 2000).

In addition to the multiple contact method, it was necessary to provide monetary compensation to participants who completed the survey. Provision of a financial incentive is known to improve response rates in survey studies (Dillman, 2000). Dillman (2000) recommends providing a token financial incentive with initial mailings in order to invoke a feeling of social goodwill that entices the person to participate, rather than promising to send a financial incentive after survey completion which functions more as a payment. Due to administrative and funding constraints, a post-survey financial payment method was chosen. This was necessary to compensate producers for the time it took to fill out the questionnaire - 36 questions, some quite complex and requiring farmers to consult their records. Pennings et al. (2002) found that in addition to timing of survey implementation, length of survey and amount of compensation were two other factors that affected farmer participation. The median dollar amount that producers expected to receive in the Pennings et al. (2002) study was \$10. Discussions with WV Small Farm Center faculty with experience in surveying producers also concurred that $\$ 10$ compensation was the appropriate sum given the nature and length of the questionnaire. Funding was obtained from a USDA Northeast Sustainable Agriculture Research and Education (NESARE) Program Graduate Student Grant that allowed this recommended survey methodology to be followed. 


\section{Survey Implementation}

An initial letter was sent in February 2013 to request the participation of producers in the study (Appendix 2). Timing survey implementation according to target population is critical to achieve a better response rate (Dillman, 2000). Pennings et al. (2002) found that producers were more likely to fill out surveys that they receive in January or February because they have the time to fill them out then. Instead of sending a paper copy of the questionnaire with the initial letter of request for participation (per Dillman's (2000) TDM), a link to the online survey (available using Survey Monkey software) was included in the letter along with a code unique to the producer. The producer had the option to take the survey online instantaneously using her/his code, or s/he could request a paper copy of the survey, by sending the request letter back to us in the stamped return envelope that had been included.

People who sent their initial letter back to request a paper copy were sent a paper questionnaire and a cover letter with instructions. A green slip of paper was also included, asking the producer to write her/his address and mail it back with her/his completed survey in order to receive a $\$ 10$ gift card to either Southern States or Johnny's Seeds, per her/his preference.

The original intent was to send reminder postcards 2 weeks later only to those persons who had not responded via the online survey or to request a paper copy of the survey. However, several letters requesting a paper copy of the survey included notes indicating that people had difficulty accessing the online survey. Due to concern that this type of technical difficulty could affect response rates, a paper copy of the survey was sent along with a second letter of appeal for participation to everyone who had not responded yet. This second mailing was completed four weeks after the initial mailing, at the end of March and early April, 2013. Producers were not 
contacted a third time because it would have occurred in the summer when producers are busiest and least likely to be responsive to such requests, as Pennings et al. (2002) found in their study.

Completed surveys were received between the months of March and August 2013, with the bulk being received between March and June. Of the 1705 original requests mailed, 1511 were delivered. A total of 194 surveys were undeliverable; 116 came back marked "return to sender", and 78 contained notes that the target participant was either deceased or no longer produced food. Of the total surveys, 139 usable surveys were received online; the rest were paper questionnaires. In total, 574 completed and usable surveys were received resulting in a $38 \%$ response rate.

\section{Survey Data and Descriptive Statistics}

This section presents a comparison of survey data with data for WV farmers from the USDA-National Agricultural Statistics Service (NASS) US Census of Agriculture (2007), followed by descriptive statistics of interest.

\section{Representativeness of Survey Sample}

Surveys were received from producers residing in 56 different counties: 42 in WV, 5 in PA, 6 in $\mathrm{OH}$, and 2 in MD (Appendix 4). The following WV counties were not represented in the survey sample: Boone, Brooke, Logan, Marshall, McDowell, Mingo, Pendleton, Putnam, Summers, Raleigh, Wetzel, Wood, and Wyoming. Several of these counties are located in the northern panhandle and the southern counties where agricultural production is not as prevalent as in the rest of the state. The survey population exhibits over-representation of females (34\%) compared to the percentage of WV farmers that are female (14\%). The average age of principal 
operator in the survey sample is identical to that of the average WV farmer (58.1 years), and the age group distribution is similar (Figure 3).

\section{Figure 3. Age distribution within study sample compared to WV producers}

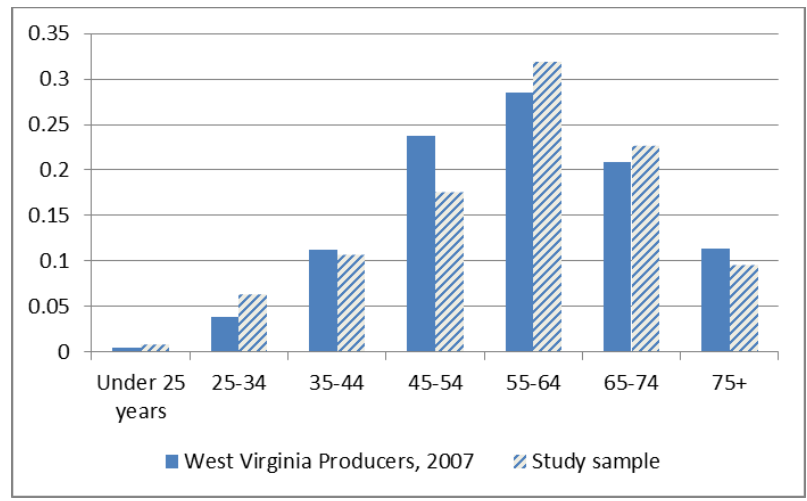

Source: Study sample data, and USDA-NASS US Census of Agriculture, 2007.

Average reported acreage of usable agricultural land (not necessarily the same as farm size) of 93.48 acres is smaller than the average farm size of 157 acres among WV farmers. In the present study, it was important to understand the area of usable acreage, rather than total farm size, so it makes sense that this number is smaller.

The percentage of farms in the sample that reported raising vegetables for sale, as well as layers, and broilers, was higher than the percentage of total WV farms that raise those products. In contrast, the percentage of farms in the sample that reported raising fattened beef was lower than the percentage of all WV farms that raise this product (Figure 4). 
Figure 4. Percentage of farms in sample that reported raising different food products compared to percentage of total WV farms that raise those products

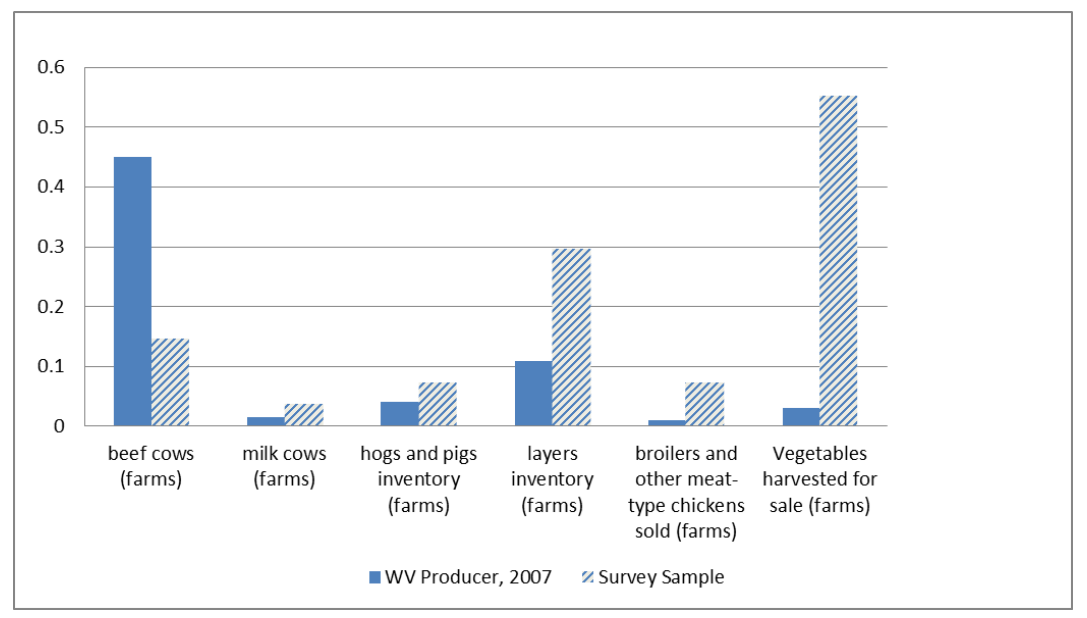

Source: Study sample data, and USDA-NASS US Census of Agriculture, 2007.

The distribution of gross sales levels among the survey sample is similar to that of WV producers, although the percentage of farms in the survey sample that gross less than $\$ 1000 /$ year is lower than the percentage among all WV producers (Figure 5).

Figure 5. Gross sales distribution within survey sample compared to gross sales distribution among WV producers

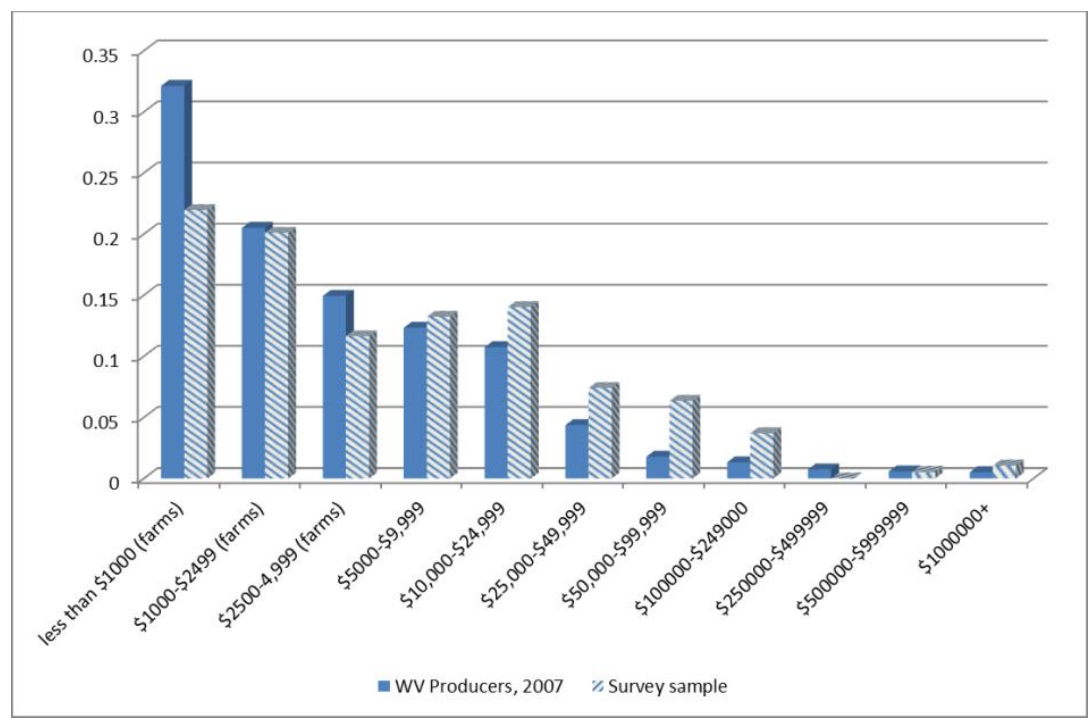

Source: Study sample data, and USDA-NASS US Census of Agriculture, 2007. 
Based on survey results, it cannot be concluded that the sample is representative of producers portrayed in USDA-NASS US Census of Agriculture (2007) data. Agricultural Census statistics are gathered from all producers who have at least $\$ 1000$ of annual sales to qualify as a farm for tax purposes. Similarly, Agricultural Census statistics only represent farms that sell product. In contrast, our sample purposively includes many farms that do not sell any agricultural products and are therefore not represented in the US Census of Agriculture statistics. The sample also includes producers that are highly engaged in local markets, which could explain the overrepresentation in higher sales categories. Therefore, it is not possible to generalize from our results to all WV farms. We can however draw inference about farms that are likely to be engaged with local food markets now or in the near future. 


\section{Descriptive Statistics}

Descriptive statistics for all survey questions may be found in Appendix 3. A brief summary is presented here.

Market participation behavior and intentions

Sixty-nine percent of survey respondents reported selling food products in 2012. Of those who sold, the average range of gross sales was $\$ 2500-\$ 4999$. The average reported percent of farm income from farmers markets was 33.59\%, Community Supported Agriculture (CSA) $(4.33 \%)$, and schools $(<1 \%)$.

With regard to expansion intentions, $47 \%$ of respondents reported intentions to produce more overall, $38 \%$ reported plans to produce the same amount overall, $6 \%$ reported plans to produce less overall, $1 \%$ reported plans to stop farming or gardening entirely, and $8 \%$ were not sure.

Access to resources

The survey sample overall exhibited high levels of access to equipment (78\%) and land owned by the operator (93\%), and moderate access to resources like water for irrigation (49\%) and family labor (47\%). A relatively small percentage of the sample has access to a high tunnel (17\%), loans or credit (18\%) or hired labor $(15 \%)$.

Non-economic factors

The most common reason for entering farming was to "develop a business to generate additional income" (24\% of respondents), followed by "other" $(22 \%)$, and "take over operation from family member or another person" (18\%). 
Sixty-three percent of respondents either agreed or strongly agreed that they planned to pass on the farm to a known successor. Only sixty-seven percent of respondents agreed or strongly agreed that farming was a viable business venture, and $67 \%$ agreed or strongly agreed that their household preferred to have off-farm work to reduce risk. Eighty percent of respondents agreed or strongly agreed that they would encourage youth to farm and $72 \%$ agreed or strongly agreed with the statement "people value my role as a farmer/gardener".

Twenty-four percent of respondents reported having ancestors that settled in WV to farm, and $73 \%$ of respondents reported being raised in WV. Of all respondents, $7 \%$ reported specifically moving to WV to farm. Sixty percent of respondents reported having some "American" ancestry, 22\% reported some German ancestry, and 6\% reported some Scot-Irish ancestry.

\section{Data Analysis}

The objectives of this study are to identify factors that influence behavior as well as to understand producers' market participation and expansion decisions. Econometric analysis is applied to identify these factors using the survey dataset obtained in this study. The software $R$ was used to conduct this analysis.

\section{Model Selection}

The issues of concern in this study require primarily the use of discrete decision making analysis. This study relies on limited dependent variable models, in which values of variables are naturally limited to a certain range due to influence of random choice mechanisms (Maddala, 1983). When a dependent variable is continuous, Ordinary Least Squares (OLS) linear regression may be employed to estimate a model. However, when it is necessary to estimate a dichotomous 
dependent variable, OLS is no longer appropriate because the outcome is restricted between zero and one, and the assumptions of homoscedasticity and normal distribution of the error term may also be violated, affecting hypothesis testing (Gujarati, 2011).

\section{Probit models}

Logit and probit models are appropriate for modeling dichotomous dependent variable outcomes because they are suited to situations when the probability of an outcome is restricted to the zero to one interval and when we must assume that the relationship between the outcome and the explanatory variables is non-linear (Gujarati, 2011). The logit and probit models are based on the idea that decisions are the result of utility maximization, represented by an unobservable utility index, $I_{i}^{*}$ that is influenced by relevant explanatory variables:

$I_{i}^{*}=B X+u_{i}$

Where $i$ refers to person $i, B X$ is the matrix of explanatory variables and $u_{i}$ is the error term. These models assume that the outcome, $Y_{i}$, of a decision will depend on this unobserved utility index. For example, individual $i$ may decide to participate in a market $\left(Y_{i}=1\right)$ or not $\left(Y_{i}=0\right)$. This decision depends on the unobserved utility index $I_{i}^{*}$, where

$Y_{i}=1$ if $I_{i}^{*} \geq 0$

$Y_{i}=0$ if $I_{i}^{*}<0$

The probability of an individual making this choice depends on the probability distribution of $Y_{i}$, which is dependent on the probability distribution of $u_{i}$, the error term. The probit model assumes that the error term is normally distributed. Therefore, the probability that the 
individual's unobserved utility index is equal to or greater than the threshold level $I_{i}^{*}$ can be estimated as follows:

$P_{i}=\operatorname{Pr}(Y=1 \mid X)=\operatorname{Pr}\left(I_{i}^{*} \leq I_{i}\right)=\operatorname{Pr}\left(Z_{i} \leq B X\right)=F(B X)$,

where $\mathrm{F}$ is the standard cumulative distribution function $(\mathrm{CDF})$ :

$F(B X)=\frac{1}{\sqrt{2 \pi}} \int_{-\infty}^{B X} e^{-z^{2} / 2} d z$

and $F\left(I_{i}\right)$ is the probit function. $P$ represents the probability that the individual will participate in the market and is measured by the area of the CDF curve from - $\infty$ to $I_{i}$. A maximum likelihood method is used to estimate the utility index and coefficients (Gujarati, 2011; Maddala, 1983):

$$
L=\prod_{y_{i}=0} F\left(-\beta^{\prime} x_{i}\right) \prod_{y_{i}=1}\left[1-F\left(-\beta^{\prime} x_{i}\right)\right.
$$

The marginal effect is calculated by multiplying coefficients by the normal density function value for all values of the explanatory variables (Gujarati, 2011).

\section{Model Specification}

\section{Model 1. Market Participation Decision}

Objective 1. Identify the factors that influence market participation behavior in WV local food markets

Following the market participation literature (Angula, 2010; Cragg, 1971) producers market participation and sales volume decisions are modeled as two separate components, with the first being the discrete decision to participate in the market, or not. In this study, a probit model is used to identify the impact of farm-level, motivational and attitudinal, and socioeconomic characteristics on the discrete market participation decision. The dependent 
variable in this model is whether the producer sold in $2012(\mathrm{Y}=1)$ or not $(\mathrm{Y}=0)$, from question 12 in the questionnaire. Explanatory variables representing socioeconomic factors, farm level factors related to production enterprises and resources, factors related to motivation for farming, and factors to capture attitudes, perceived behavioral control, and subjective norms. The model is specified as follows:

MARKET PARTICIPATION (i) $=\beta_{1} \mathrm{AGEi}+\beta_{2}$ GENDERi $+\beta_{3}$ EDUCATIONi $+\beta_{4}$ FTIMEi + $\beta_{5}$ AGLANDi $+\beta_{6}$ MKTMILESi $+\beta_{7} \mathrm{SUCCi}+\beta_{8}$ GENTIONi $+\beta_{9}$ IRRIGATEi $+\beta_{10}$ LANDOWNi+ $\beta_{11} \mathrm{HLABORi}+\beta_{12} \mathrm{FAMLABORi}+\beta_{13} \mathrm{DIETi}+\beta_{14} \mathrm{BEEFi}+\beta_{15} \mathrm{BROILERi}+\beta_{16} \mathrm{LAYERi}+$ $\beta_{17} \mathrm{PORKi}+\beta_{18} \mathrm{LAMBi}+\beta_{19} \mathrm{MGOATi}+\beta_{20} \mathrm{DCOWi}+\beta_{21}$ FRUITi $+\beta_{22}$ VEGi $+\beta_{23}$ ROLEVALUEi + $\beta_{24}$ YOUTHi $+\beta_{25}$ ANFARMi $+\beta_{26}$ ANGERMi $+\beta_{27}$ ANSIRi $+\beta_{28}$ RFARMi $+\beta_{29}$ RINCi+ $\beta_{30}$ VIABLEi $+\beta_{31}$ OFFRISKi $+u_{i}$, where $u_{i}$ is assumed to be normally distributed.

Definitions and descriptive statistics for variables included in Model 1 are displayed in Table 1. 
Table 1. Descriptive statistics for variables included in Model 1

\begin{tabular}{|c|c|c|c|c|c|c|}
\hline$N=352$ & Code & Mean & Std. Dev. & Median & Min & Max \\
\hline \multicolumn{7}{|l|}{ Dependent Variable } \\
\hline Sold in 2012 (yes=1) & & 0.72 & 0.45 & 1.00 & 0 & 1 \\
\hline \multicolumn{7}{|l|}{ Explanatory Variables } \\
\hline Age (years) & AGE & 56.44 & 13.43 & 57.00 & 15 & 91 \\
\hline Gender $($ female $=1)$ & GEN & 0.35 & 0.48 & 0.00 & 0 & 1 \\
\hline Education & EDU & 4.76 & 1.63 & 5.00 & 1 & 7 \\
\hline Household Income & HHINCOME & 8.82 & 4.37 & 9.00 & 1 & 18 \\
\hline Operator works full-time off the farm (yes $=1$ ) & FTIME & 0.37 & 0.48 & 0.00 & 0 & 1 \\
\hline Number of acres of usable agricultural land to which the operator has access (acres) & AGLAND & 87.90 & 193.09 & 25.00 & 0 & 2000 \\
\hline Distance to market (miles) & MKTMILES & 13.27 & 12.22 & 10.00 & 0 & 100 \\
\hline Plan to pass farm/garden on to a known successor (Strongly agree or agree $=1$ ) & SUCC & 0.62 & 0.49 & 1.00 & 0 & 1 \\
\hline Number generations land has been in family & GENTION & 1.99 & 1.37 & 1.00 & 0 & 9 \\
\hline Access to water for irrigation (yes $=1$ ) & IRRIGATE & 0.52 & 0.50 & 1.00 & 0 & 1 \\
\hline Land owned by operator (yes $=1$ ) & LANDOWN & 0.96 & 0.19 & 1.00 & 0 & 1 \\
\hline Hired laborers (yes $=1$ ) & HLABOR & 0.16 & 0.37 & 0.00 & 0 & 1 \\
\hline Family laborers (yes $=1$ ) & FAMLABOR & 0.49 & 0.50 & 0.00 & 0 & 1 \\
\hline Percentage of diet made up of food products that you raise & DIET & 0.42 & 0.27 & 0.40 & 0 & 1 \\
\hline Raised fattened beef in 2012 (yes = 1) & BEEF & 0.17 & 0.38 & 0.00 & 0 & 1 \\
\hline Raised broilers in 2012 (yes = 1) & BROILER & 0.11 & 0.31 & 0.00 & 0 & 1 \\
\hline Raised layers in 2012 (yes = 1) & LAYER & 0.35 & 0.48 & 0.00 & 0 & 1 \\
\hline Raised pork in 2012 (yes $=1)$ & PORK & 0.10 & 0.30 & 0.00 & 0 & 1 \\
\hline Raised lamb in $2012($ yes $=1)$ & LAMB & 0.08 & 0.28 & 0.00 & 0 & 1 \\
\hline Raised meat goats in 2012 (yes $=1$ ) & MGOAT & 0.05 & 0.21 & 0.00 & 0 & 1 \\
\hline Raised dairy cows in 2012 (yes $=1$ ) & DCOW & 0.05 & 0.21 & 0.00 & 0 & 1 \\
\hline Raised fruit trees in 2012 (yes $=1$ ) & FRUIT & 0.51 & 0.50 & 1.00 & 0 & 1 \\
\hline Raised vegetables in 2012 (yes $=1)$ & VEG & 0.87 & 0.34 & 1.00 & 0 & 1 \\
\hline People value my role as a farmer/gardener. (yes $=1$ ) & ROLEVALUE & 0.71 & 0.45 & 1.00 & 0 & 1 \\
\hline I would encourage youth to pursue farming. (yes =1) & YOUTH & 0.82 & 0.39 & 1.00 & 0 & 1 \\
\hline Ancestors settled to farm (yes $=1$ ) & ANFARM & 0.31 & 0.46 & 0.00 & 0 & 1 \\
\hline Ancestors: German (yes = 1) & ANGERM & 0.20 & 0.40 & 0.00 & 0 & 1 \\
\hline Ancestors: Scot-Irish (yes $=1$ ) & ANSCOTIR & 0.08 & 0.27 & 0.00 & 0 & 1 \\
\hline Reason for entering farming: Take over farm from family or other person $($ yes $=1$ ) & RFARM & 0.18 & 0.38 & 0.00 & 0 & 1 \\
\hline Reason for entering farming: develop business to generate additional income (yes $=1$ ) & RINC & 0.26 & 0.44 & 0.00 & 0 & 1 \\
\hline Farming is a viable business venture. (Strongly agree or agree $=1$ ) & VIABLE & 0.66 & 0.48 & 1.00 & 0 & 1 \\
\hline Household prefers to have off-farm income as well to reduce risk. (Strongly agree or agree $=1$ ) & OFFRISK & 0.72 & 0.45 & 1.00 & 0 & 1 \\
\hline
\end{tabular}




\section{Model 2: Supply Volume Behavior}

Objective 2. Examine the factors that influence commercial producers' sales volume

The second part of understanding producers' supply response in markets is understanding their sales volume decision or behavior. Market participation literature has explored this using limited dependent variable regression models like the Tobit and the "Double Hurdle" models, in which the impact of the first discrete decision influences the second continuous decision (Angula, 2010; Cragg, 1971; Detre, et al. 2012) to explore the impact on the continuous dependent variable which is gross sales. In this study, the decisions are regarded as sequential in theory but are separated into two different models because it was not important to the research question to analyze the impact of the market participation decision on the sales volume decision; rather, this study analyzes market entry, not market channel selection which is how the double hurdle model has been applied (Angula, 2010; Detre et al, 2012).

Since the gross sales data are categorical, following Brown et al. (2006) the mid-point of each gross sales range was calculated and used as the dependent variable representing sales volume, from question 17 in the questionnaire. Ordinary Least Squares (OLS) linear regression model was used and specified as follows:

GROSS SALES(i) $=\beta_{1}$ AGEi $+\beta_{2}$ GENDERi $+\beta_{3}$ EDUCATIONi $+\beta_{4}$ FTIMEi + $\beta_{5}$ AGLANDi $+\beta_{6}$ MKTMILESi $+\beta_{7} \mathrm{SUCCi}+\beta_{8}$ GENTIONi $+\beta_{9}$ IRRIGATEi $+\beta_{10}$ LANDOWNi+ $\beta_{11} \mathrm{HLABORi}+\beta_{12} \mathrm{FAMLABORi}+\beta_{13} \mathrm{DIETi}+\beta_{14} \mathrm{BEEFi}+\beta_{15} \mathrm{BROILERi}+\beta_{16} \mathrm{LAYERi}+$ $\beta_{17} \mathrm{PORKi}+\beta_{18} \mathrm{LAMBi}+\beta_{19} \mathrm{MGOATi}+\beta_{20} \mathrm{DCOWi}+\beta_{21} \mathrm{FRUITi}+\beta_{22} \mathrm{VEGi}+\beta_{23} \mathrm{ROLEVALUEi}+$ $\beta_{24}$ YOUTHi $+\beta_{25}$ ANFARMi $+\beta_{26}$ ANGERMi $+\beta_{27}$ ANSIRi $+\beta_{28}$ RFARMi $+\beta_{29}$ RINCi+ $\beta_{30} \mathrm{VIABLEi}+\beta_{31}$ OFFRISKi $+u_{i}$, where $u_{i}$ is assumed to be normally distributed. 
Descriptive statistics for the variables included in Model 2 are found in Table 2. 
Table 2: Descriptive Statistics for Variables Included in Model 2

\begin{tabular}{|c|c|c|c|c|c|c|}
\hline$N=363$ & CODE & Mean & Std. Dev. & Median & Min & Max \\
\hline \multicolumn{7}{|l|}{ Dependent Variable } \\
\hline Gross Sales Level, 2012 & & 25,464 & 113,953 & 1,750 & 0 & $\$ 1,000,000$ \\
\hline \multicolumn{7}{|l|}{ Explanatory Variables } \\
\hline Age (years) & AGE & 56.58 & 13.37 & 58.00 & 15 & 91 \\
\hline Gender (female $=1$ ) & GEN & 0.35 & 0.48 & 0.00 & 0 & 1 \\
\hline Education & EDU & 4.76 & 1.63 & 5.00 & 1 & 7 \\
\hline Operator works full-time off the farm $($ yes $=1)$ & FTIME & 0.37 & 0.48 & 0.00 & 0 & 1 \\
\hline Number of acres of usable agricultural land to which the operator has access (acres) & AGLAND & 94.04 & 216.30 & 25.00 & 0 & 2000 \\
\hline Distance to market (miles) & MKTMILES & 13.22 & 12.07 & 10.00 & 0 & 100 \\
\hline Plan to pass farm/garden on to a known successor (Strongly agree or agree $=1$ ) & SUCC & 0.62 & 0.49 & 1.00 & 0 & 1 \\
\hline Number generations land has been in family & GENTION & 1.99 & 1.36 & 1.00 & 0 & 9 \\
\hline Access to water for irrigation (yes $=1$ ) & IRRIGATE & 0.52 & 0.50 & 1.00 & 0 & 1 \\
\hline Land owned by operator (yes $=1$ ) & LANDOWN & 0.96 & 0.19 & 1.00 & 0 & 1 \\
\hline Hired laborers (yes $=1$ ) & HLABOR & 0.16 & 0.36 & 0.00 & 0 & 1 \\
\hline Family laborers (yes $=1$ ) & FAMLABOR & 0.48 & 0.50 & 0.00 & 0 & 1 \\
\hline Percentage of diet made up of food products that you raise & DIET & 0.42 & 0.27 & 0.40 & 0 & 1 \\
\hline Raised fattened beef in 2012 (yes = 1) & BEEF & 0.17 & 0.37 & 0.00 & 0 & 1 \\
\hline Raised broilers in $2012($ yes $=1)$ & BROILER & 0.10 & 0.30 & 0.00 & 0 & 1 \\
\hline Raised layers in 2012 (yes = 1) & LAYER & 0.34 & 0.47 & 0.00 & 0 & 1 \\
\hline Raised pork in $2012($ yes $=1)$ & PORK & 0.09 & 0.29 & 0.00 & 0 & 1 \\
\hline Raised lamb in $2012($ yes = 1) & LAMB & 0.08 & 0.28 & 0.00 & 0 & 1 \\
\hline Raised meat goats in 2012 (yes =1) & MGOAT & 0.05 & 0.22 & 0.00 & 0 & 1 \\
\hline Raised dairy cows in 2012 (yes = 1) & DCOW & 0.04 & 0.21 & 0.00 & 0 & 1 \\
\hline Raised fruit trees in 2012 (yes $=1$ ) & FRUIT & 0.49 & 0.50 & 0.00 & 0 & 1 \\
\hline Raised vegetables in $2012($ yes $=1)$ & VEG & 0.87 & 0.34 & 1.00 & 0 & 1 \\
\hline People value my role as a farmer/gardener. (yes $=1)$ & ROLEVALUE & 0.71 & 0.46 & 1.00 & 0 & 1 \\
\hline I would encourage youth to pursue farming. (yes $=1$ ) & YOUTH & 0.81 & 0.39 & 1.00 & 0 & 1 \\
\hline Ancestors settled to farm (yes $=1$ ) & ANFARM & 0.31 & 0.46 & 0.00 & 0 & 1 \\
\hline Ancestors: German (yes $=1$ ) & ANGERM & 0.21 & 0.41 & 0.00 & 0 & 1 \\
\hline Ancestors: Scot-Irish (yes = 1) & ANSIR & 0.07 & 0.26 & 0.00 & 0 & 1 \\
\hline Reason for entering farming: Take over farm from family or other person $(\mathrm{yes}=1)$ & RFARM & 0.18 & 0.38 & 0.00 & 0 & 1 \\
\hline Reason for entering farming: develop business to generate additional income $(\mathrm{yes}=1)$ & RINC & 0.26 & 0.44 & 0.00 & 0 & 1 \\
\hline Farming is a viable business venture. (Strongly agree or Agree $=1$ ) & VIABLE & 0.66 & 0.48 & 1.00 & 0 & 1 \\
\hline Household prefers to have off-farm income as well to reduce risk. (Strongly agree or agree $=1$ ) & OFFRISK & 0.72 & 0.45 & 1.00 & 0 & 1 \\
\hline
\end{tabular}




\section{Model 3. Market Participation Intentions}

Objective 3. Explore the factors that influence the market participation intentions of noncommercial potential new entrants

In model 3, the possibility that those who do not currently sell could decide to participate in local food markets is explored. Different factors that could influence producers interested in participating in the market or their ability to do so are included. According to the Theory of Planned Behavior (Azjen, 1991), and asserted in economic studies (Bartolini et al., 2011), intentions are a reliable predictor of future behavior. As the purpose and application of this study are related to understanding the potential and trajectory of supply growth, it is important to analyze intentions as well as behavior. Model 3 therefore analyzes the market participation intentions of the group of producers in the dataset who did not sell in 2012 in order to identify factors that influence these intentions. The dependent variable for this model is whether the producer intends to sell within the next two years $(\mathrm{Y}=1)$. This market orientation variable was coded as one if producers indicated interest in selling product in any marketing channel in the next two years (from question 10 in the questionnaire). If producers did not indicate interest in any market channels or marked "none" they were coded with a zero. As this is another dichotomous choice, a probit model is appropriate. Explanatory variables chosen to include in the model represent socioeconomic factors, farm level factors, and reasons why producers did not sell in 2012. The model is specified as follows:

MARKET PARTICIPATION INTENTIONS(i $)=\beta_{1}$ AGEi $+\beta_{2}$ GENDERi $+\beta_{3}$ EDUCATIONi + $\beta_{4}$ FTIMEi $+\beta_{5}$ AGLANDi $+\beta_{6}$ MKTMILESi $+\beta_{7}$ DIETi $+\beta_{8}$ HOBBYi $+\beta_{9}$ RETIREDi+ $\beta_{10}$ FSAFETYi $+\beta_{11}$ REGSi $+\beta_{12}$ PESTi $+\beta_{13}$ MKTFARi $+\beta_{14}$ TIMEi $+\beta_{15}$ LABORi + $\beta_{16}$ NOPROFITi $+\beta_{17}$ NODEMANDi $+\beta_{18}$ YOUTHi $+\beta_{19}$ ANFARMi $+\beta_{20}$ ANGERMi + $\beta_{21}$ ANSIRi $+\beta_{22}$ RFARMi $+\beta_{23}$ RINCi $+\beta_{24}$ VIABLEi $+\beta_{25}$ OFFRISKi $+u_{i}$, 
where $u_{i}$ is assumed to be normally distributed.

Descriptive statistics and definitions for the variables used in the model are presented in Table 3. 
Table 3. Descriptive statistics of variables included in Model 3

\begin{tabular}{|c|c|c|c|c|c|c|}
\hline$N=91$ & CODE & Mean & Std. Dev. & Median & Min & Max \\
\hline \multicolumn{7}{|l|}{ Dependent Variable } \\
\hline Intend to sell products in the future (yes $=1$ ) & & 0.55 & 0.50 & 1.00 & 0.00 & 1.00 \\
\hline \multicolumn{7}{|l|}{ Explanatory Variables } \\
\hline Age (years) & AGE & 54.86 & 14.37 & 55.00 & 24.00 & 88.00 \\
\hline Gender (female = 1) & GEN & 0.36 & 0.48 & 0.00 & 0.00 & 1.00 \\
\hline Education (7 possible levels) & EDU & 4.79 & 1.57 & 5.00 & 2.00 & 7.00 \\
\hline Household Income (18 possible levels) & HHINCOME & 8.34 & 4.23 & 7.00 & 1.00 & 18.00 \\
\hline Operator works full-time off the farm $($ yes $=1)$ & FTIME & 0.44 & 0.50 & 0.00 & 0.00 & 1.00 \\
\hline Number of acres of usable agricultural land to which the operator has access (acres) & AGLAND & 50.14 & 99.08 & 18.00 & 0.00 & 700.00 \\
\hline Distance to market (miles) & MKTMILES & 11.38 & 7.53 & 10.00 & 0.50 & 35.00 \\
\hline Percentage of diet made up of food products that you raise & DIET & 0.36 & 0.24 & 0.30 & 0.01 & 0.90 \\
\hline Reason for entering farming: Take over farm from family or other person $($ yes $=1)$ & RFARM & 0.16 & 0.37 & 0.00 & 0.00 & 1.00 \\
\hline Reason for entering farming: develop business to generate additional income (yes $=1$ ) & RINC & 0.08 & 0.27 & 0.00 & 0.00 & 1.00 \\
\hline Farming is a viable business venture. (Strongly agree or agree $=1$ ) & VIABLE & 0.65 & 0.48 & 1.00 & 0.00 & 1.00 \\
\hline Household prefers to have off-farm income as well to reduce risk. (Strongly agree or agree $=1$ ) & OFFRISK & 0.75 & 0.44 & 1.00 & 0.00 & 1.00 \\
\hline \multicolumn{7}{|c|}{ Reasons for not selling in 2012 (Likert scale: $1=$ strongly disagree, $2=$ disagree, $3=$ =neither agree nor disagree, $4=$ agree, $5=$ strongly agree) } \\
\hline Not interested in selling; just a hobby & HOBBY & 3.26 & 1.05 & 3.00 & 1.00 & 5.00 \\
\hline Used to sell but now retired & RETIRED & 2.57 & 1.17 & 3.00 & 1.00 & 5.00 \\
\hline Prefer to give away extra produce rather than sell it & EXTRA & 3.55 & 1.04 & 4.00 & 1.00 & 5.00 \\
\hline Afraid of consequences if product makes someone sick & FSAFETY & 2.88 & 1.14 & 3.00 & 1.00 & 5.00 \\
\hline Complicated regulations & REGS & 3.00 & 1.05 & 3.00 & 1.00 & 5.00 \\
\hline Pest and Disease problems & PEST & 2.69 & 1.01 & 2.00 & 1.00 & 5.00 \\
\hline Too far to sell at a profitable market outlet & MKTFAR & 2.71 & 1.07 & 3.00 & 1.00 & 5.00 \\
\hline Don't have the time to sell & TIME & 3.30 & 1.05 & 3.00 & 1.00 & 5.00 \\
\hline Difficulty hiring type of labor needed & LABOR & 2.96 & 1.03 & 3.00 & 1.00 & 5.00 \\
\hline Believe it wouldn't be profitable & NOPROFIT & 3.03 & 1.08 & 3.00 & 1.00 & 5.00 \\
\hline Lack of demand in local markets & NODEMAND & 2.54 & 0.92 & 2.00 & 1.00 & 5.00 \\
\hline
\end{tabular}




\section{Model 4. Expansion Intentions}

Objective 4. Identify the factors that influence expansion intentions of market-oriented producers

Model 4 seeks to understand the factors that influence the potential for expanded supply in local markets by examining the expansion decisions of those producers that have intentions to sell products. A stated intentions theoretical model with a probit empirical model is employed. Florkowski et al. (2000) modeled intentions to expand blueberry production in this way. More sophisticated approaches to estimating intentions that would provide information on magnitude would use a dependent variable such as percentage planned increase in acreage or planned increase in gross sales. However, these options were ruled out due to non-response in parts of the questionnaire about the magnitude of future intentions, and also due to doubt about accuracy of such scale projections.

The dependent variable EXPANSION INTENTIONS is defined as one if the producer is interested in expanding, and zero if they are not (from question 7 in the questionnaire). Because this study is interested in expansion in local markets, the dataset for this model was limited to producers that either currently sell their products or have intentions to do so in the future (from question 10 in the questionnaire). In other words, a producer who reported that $\mathrm{s} / \mathrm{he}$ is interested in expanding (from question 7) who did not also report that s/he intended to sell products was not included in the dataset for this model because it is assumed that her/his expansion will not impact supply in local markets.

The probit model is specified as follows: 
EXPANSION INTENTIONS (i) $=\beta_{1}$ AGEi $+\beta_{2}$ GENDERi $+\beta_{3}$ EDUCATIONi $+\beta_{4}$ FTIMEi + $\beta_{5}$ AGLANDi $+\beta_{6}$ MKTMILESi $+\beta_{7}$ SUCCi $+\beta_{8}$ GENTIONi $+\beta_{9}$ IRRIGATEi $+\beta_{10}$ LANDOWNi+ $\beta_{11} \mathrm{HLABORi}+\beta_{12}$ FAMLABOR $+\beta_{13}$ DIETi $+\beta_{14}$ BEEFi $+\beta_{15}$ BROILER $+\beta_{16}$ LAYERi + $\beta_{17} \mathrm{PORKi}+\beta_{18} \mathrm{LAMBi}+\beta_{19} \mathrm{MGOATi}+\beta_{20} \mathrm{DCOWi}+\beta_{21}$ FRUITi $+\beta_{22}$ VEGi $+\beta_{23}$ ROLEVALUEi + $\beta_{24}$ YOUTHi $+\beta_{25}$ ANFARMi $+\beta_{26}$ ANGERMi $+\beta_{27}$ ANSIRi $+\beta_{28}$ RFARMi $+\beta_{29}$ RINCi+ $\beta_{30}$ VIABLEi $+\beta_{31}$ OFFRISKi+ $u_{i}$, where $u_{i}$ is assumed to be normally distributed.

Descriptive statistics for the variables included in this model can be found in Table 4 .

Following, Table 5 provides an overview of the analytic approach of this study. 
Table 4: Descriptive Statistics for Variables Included in Model 4

\begin{tabular}{|c|c|c|c|c|c|c|}
\hline$N=363$ & CODE & Mean & Std. Dev. & Median & Min & Max \\
\hline \multicolumn{7}{|l|}{ Dependent Variable } \\
\hline Intend to expand more $($ yes $=1$ ) & & 0.58 & 0.49 & 1.00 & 0 & 1 \\
\hline \multicolumn{7}{|l|}{ Explanatory Variables } \\
\hline Age (years) & AGE & 55.69 & 13.19 & 57.00 & 15 & 91 \\
\hline Gender (female = 1) & GEN & 0.33 & 0.47 & 0.00 & 0 & 1 \\
\hline Education (7 possible levels) & EDU & 4.75 & 1.61 & 4.50 & 1 & 7 \\
\hline Household Income (18 possible levels) & HHINCOME & 8.91 & 4.36 & 9.00 & 1 & 18 \\
\hline Operator works full-time off the farm (yes $=1$ ) & FTIME & 0.40 & 0.49 & 0.00 & 0 & 1 \\
\hline Number of acres of usable agricultural land to which the operator has access (acres) & AGLAND & 93.76 & 201.82 & 25.00 & 0 & 2000 \\
\hline Distance to market (miles) & MKTMILES & 13.47 & 12.75 & 10.00 & 0 & 100 \\
\hline Plan to pass farm/garden on to a known successor (Strongly agree or agree $=1$ ) & SUCC & 0.61 & 0.49 & 1.00 & 0 & 1 \\
\hline Number generations land has been in family & GENTION & 1.98 & 1.40 & 1.00 & 0 & 9 \\
\hline Access to water for irrigation (yes $=1$ ) & IRRIGATE & 0.54 & 0.50 & 1.00 & 0 & 1 \\
\hline Land owned by operator (yes = 1) & LANDOWN & 0.97 & 0.17 & 1.00 & 0 & 1 \\
\hline Hired laborers (yes = 1) & HLABOR & 0.17 & 0.38 & 0.00 & 0 & 1 \\
\hline Family laborers $($ yes $=1$ ) & FAMLABOR & 0.50 & 0.50 & 0.00 & 0 & 1 \\
\hline Percentage of diet made up of food products that you raise & DIET & 0.43 & 0.27 & 0.40 & 0 & 1 \\
\hline Raised fattened beef in 2012 (yes = 1) & BEEF & 0.18 & 0.38 & 0.00 & 0 & 1 \\
\hline Raised broilers in 2012 (yes $=1$ ) & BROILER & 0.12 & 0.32 & 0.00 & 0 & 1 \\
\hline Raised layers in $2012($ yes = 1) & LAYER & 0.38 & 0.48 & 0.00 & 0 & 1 \\
\hline Raised pork in 2012 (yes = 1) & PORK & 0.10 & 0.30 & 0.00 & 0 & 1 \\
\hline Raised lamb in 2012 (yes = 1) & LAMB & 0.10 & 0.30 & 0.00 & 0 & 1 \\
\hline Raised meat goats in $2012($ yes $=1)$ & MGOAT & 0.05 & 0.23 & 0.00 & 0 & 1 \\
\hline Raised dairy cows in $2012($ yes $=1)$ & DCOW & 0.05 & 0.23 & 0.00 & 0 & 1 \\
\hline Raised fruit trees in 2012 (yes = 1) & FRUIT & 0.50 & 0.50 & 0.50 & 0 & 1 \\
\hline Raised vegetables in $2012($ yes $=1)$ & VEG & 0.85 & 0.35 & 1.00 & 0 & 1 \\
\hline People value my role as a farmer/gardener. (yes $=1$ ) & ROLEVALUE & 0.71 & 0.45 & 1.00 & 0 & 1 \\
\hline I would encourage youth to pursue farming. (yes = 1) & YOUTH & 0.83 & 0.38 & 1.00 & 0 & 1 \\
\hline Ancestors settled to farm (yes = 1) & ANFARM & 0.30 & 0.46 & 0.00 & 0 & 1 \\
\hline Ancestors: German (yes = 1) & ANGERM & 0.19 & 0.39 & 0.00 & 0 & 1 \\
\hline Ancestors: Scot-Irish (yes = 1) & ANSIR & 0.08 & 0.27 & 0.00 & 0 & 1 \\
\hline Reason for entering farming: Take over farm from family or other person (yes =1) & RFARM & 0.19 & 0.39 & 0.00 & 0 & 1 \\
\hline Reason for entering farming: develop business to generate additional income (yes $=1$ ) & RINC & 0.29 & 0.45 & 0.00 & 0 & 1 \\
\hline Farming is a viable business venture. (Strongly agree or Agree $=1$ ) & VIABLE & 0.67 & 0.47 & 1.00 & 0 & 1 \\
\hline Household prefers to have off-farm income as well to reduce risk. (Strongly agree or agree $=1$ ) & OFFRISK & 0.70 & 0.46 & 1.00 & 0 & 1 \\
\hline
\end{tabular}


Table 5. Study Overview: Research Questions and Analytical Models

\begin{tabular}{|l|l|l|l|l|}
\hline Issue of Interest & $\begin{array}{c}\text { MARKET } \\
\text { PARTICIPATION } \\
\text { BEHAVIOR }\end{array}$ & $\begin{array}{c}\text { SUPPLY } \\
\text { VOLUME } \\
\text { BEHAVIOR }\end{array}$ & $\begin{array}{l}\text { MARKET } \\
\text { PARTICIPATION } \\
\text { INTENTIONS }\end{array}$ & $\begin{array}{l}\text { EXPANSION } \\
\text { INTENTIONS }\end{array}$ \\
\hline $\begin{array}{l}\text { Research do producers } \\
\text { Question }\end{array}$ & $\begin{array}{l}\text { What factors } \\
\text { in the market }\end{array}$ & $\begin{array}{l}\text { What factors } \\
\text { influence potential } \\
\text { new market } \\
\text { entrants } \text { market } \\
\text { influence sales } \\
\text { volume decisions? }\end{array}$ & $\begin{array}{l}\text { What influences } \\
\text { producers to } \\
\text { expand? }\end{array}$ \\
\hline Model & $\begin{array}{l}\text { Model 1: Decision } \\
\text { to Participate in the } \\
\text { Market (Behavior) }\end{array}$ & $\begin{array}{l}\text { Model 2: Sales } \\
\text { Volume Decision } \\
\text { (Behavior) }\end{array}$ & $\begin{array}{l}\text { Mode 3: Intentions } \\
\text { to Participate in the } \\
\text { Market }\end{array}$ & $\begin{array}{l}\text { Model 4: } \\
\text { Expansion } \\
\text { Intentions }\end{array}$ \\
\hline $\begin{array}{l}\text { Sample } \\
\text { Population }\end{array}$ & All producers & $\begin{array}{l}\text { Producers that sold } \\
\text { in 2012 }\end{array}$ & $\begin{array}{l}\text { Producers that did } \\
\text { not sell in 2012 }\end{array}$ & $\begin{array}{l}\text { Producers that } \\
\text { indicated interest } \\
\text { in selling within } \\
\text { the next two } \\
\text { years }\end{array}$ \\
\hline $\begin{array}{l}\text { Dependent } \\
\text { Variable } \\
\text { Description }\end{array}$ & $\begin{array}{l}\text { Sold in 2012 }(=1) \\
\text { vs. did not sell in }\end{array}$ & $\begin{array}{l}\text { Sales Level } \\
\text { (continuous) }\end{array}$ & $\begin{array}{l}\text { Plan to sell in } \\
\text { market in next two } \\
\text { years (=1) vs. no } \\
\text { plans to sell in next } \\
\text { two years (=0) }\end{array}$ & $\begin{array}{l}\text { Intend to expand } \\
\text { in next two years } \\
\text { (=1) vs. no } \\
\text { expansion (=0) }\end{array}$ \\
\hline
\end{tabular}




\section{CHAPTER 4. RESULTS AND DISCUSSION}

\section{Model 1: Market Participation Decision: "To sell or not to sell"}

In order to understand which factors influence the decision to participate in the market, or sell

food, rather than use it for another function, a probit model was estimated. The model is assumed to be significant overall, as goodness of fit measures are adequate, with a McFadden $\mathrm{R}^{2}$ of 0.503 and a likelihood ratio test result of 73.50 for which the chi-squared value (32) was significant $(\mathrm{p}=4.14 \mathrm{e}-05)$. Table 6 presents probit model results, including coefficients and marginal effects. Variables that were significant ( $\mathrm{p}$-value $<0.10)$ are in bold. 
Table 6. "Market Participation" Probit Model Results and Marginal Effects

\begin{tabular}{|c|c|c|c|c|c|}
\hline Description of Variable & Estimate & $\begin{array}{l}\text { Std. } \\
\text { Error }\end{array}$ & $z$ value & $\operatorname{Pr}(>|z|)$ & $\begin{array}{c}\text { Marginal } \\
\text { Effects }\end{array}$ \\
\hline (Intercept) & -2.58 & 1.88 & -1.37 & 0.171 & -0.712 \\
\hline Age & 0.01 & 0.01 & 0.99 & 0.324 & 0.002 \\
\hline Gender & -0.01 & 0.19 & -0.08 & 0.936 & -0.004 \\
\hline Education & 0.01 & 0.06 & 0.19 & 0.851 & 0.003 \\
\hline Household Income & 0.03 & 0.02 & 1.30 & 0.195 & 0.007 \\
\hline Operator works full-time off the farm & -0.04 & 0.19 & -0.23 & 0.817 & -0.012 \\
\hline $\begin{array}{l}\text { Number of acres of usable agricultural land to } \\
\text { which the operator has access }\end{array}$ & 0.00 & 0.00 & 1.24 & 0.216 & 0.000 \\
\hline Distance to market (miles) & 0.00 & 0.01 & 0.40 & 0.687 & 0.001 \\
\hline Plan to pass farm/garden on to a known successor & -0.30 & 0.18 & -1.64 & 0.101 & -0.084 \\
\hline Number generations land in family & -0.03 & 0.07 & -0.48 & 0.631 & -0.009 \\
\hline Access to water for irrigation & -0.09 & 0.17 & -0.49 & 0.622 & -0.024 \\
\hline Land owned by operator & 0.22 & 0.49 & 0.45 & 0.656 & 0.060 \\
\hline Hired laborers & 0.35 & 0.27 & 1.31 & 0.191 & 0.098 \\
\hline Family laborers & 0.16 & 0.17 & 0.93 & 0.352 & 0.044 \\
\hline $\begin{array}{l}\text { Percentage of diet made up of food products } \\
\text { that you raise }\end{array}$ & 0.66 & $\mathbf{0 . 3 4}$ & 1.94 & $\mathbf{0 . 0 5 3}$ & 0.183 \\
\hline Raised fattened beef in 2012 & -0.22 & 0.24 & -0.89 & 0.373 & -0.060 \\
\hline Raised broilers in 2012 & 0.72 & 0.42 & 1.70 & 0.090 & 0.198 \\
\hline Raised layers in 2012 & 0.31 & 0.20 & 1.54 & 0.125 & 0.085 \\
\hline Raised pork in 2012 & 0.09 & 0.35 & 0.26 & 0.799 & 0.025 \\
\hline Raised lamb in 2012 & 0.24 & 0.35 & 0.68 & 0.494 & 0.065 \\
\hline Raised meat goats in 2012 & 0.18 & 0.51 & 0.35 & 0.726 & 0.050 \\
\hline Raised dairy cows in 2012 & 0.14 & 0.49 & 0.29 & 0.775 & 0.039 \\
\hline Raised fruit trees in 2012 & -0.19 & 0.17 & -1.13 & 0.258 & -0.052 \\
\hline Raised vegetables in 2012 & -0.55 & 0.29 & -1.91 & 0.056 & -0.152 \\
\hline People value my role as a farmer/gardener. & 0.30 & 0.18 & 1.64 & 0.101 & 0.083 \\
\hline I would encourage youth to pursue farming. & 0.34 & 0.21 & 1.57 & 0.116 & 0.093 \\
\hline Ancestors settled to farm & -0.29 & $\mathbf{0 . 1 8}$ & -1.66 & 0.098 & -0.081 \\
\hline Ancestors: German & -0.09 & 0.20 & -0.47 & 0.640 & -0.026 \\
\hline Ancestors: Scot-Irish & 0.18 & 0.31 & 0.58 & 0.560 & 0.050 \\
\hline $\begin{array}{l}\text { Reason for entering farming: Take over farm } \\
\text { from family or another person }\end{array}$ & 0.33 & 0.25 & 1.33 & 0.185 & 0.092 \\
\hline $\begin{array}{l}\text { Reason for entering farming: develop business } \\
\text { to generate additional income }\end{array}$ & 0.94 & $\mathbf{0 . 2 3}$ & 4.12 & 0.000 & 0.259 \\
\hline Farming is a viable business venture. & -0.37 & 0.18 & -2.05 & 0.041 & -0.102 \\
\hline $\begin{array}{l}\text { Household prefers to have off-farm income as } \\
\text { well to reduce risk. }\end{array}$ & -0.11 & 0.18 & -0.58 & 0.563 & -0.029 \\
\hline
\end{tabular}


The model results indicated that several farm-level characteristics and characteristics related to the attitudes and motivation of the producer are significant predictors of whether the producer will sell her/his product. According to the model, producers who reported growing vegetables were $15.2 \%$ less likely to sell than those who did not report growing vegetables. In contrast, producers who reported having broilers on their farms were $19.8 \%$ more likely to sell products they produced than those without broilers. No other production enterprise appeared to influence the market participation decision of producers in a significant way. The fact that having vegetables reduced the likelihood of selling is perhaps due to the fact that many people have gardens. Eighty-five percent of respondents indicated they grew vegetables, but only eight percent raised meat chickens or broilers. This model indicates that people that decide to raise broilers are perhaps doing so in order to sell their products. Producers that reported raising a greater percentage of their diet themselves were also $18.3 \%$ more likely to sell. This is contrary to our expectation that producers dedicated to self-provisioning are less likely to participate in the market. However, it could be that producers that participate in the market have enough volume of different goods that they easily cover a greater proportion of their own diet by default. Percentage of diet produced in this sense may be understood as a byproduct of a producer's volume and sales decisions, not a factor that would influence their sales decision in the first place.

Several attitudinal or motivational factors appeared to influence producers' decisions to participate in the market. Those farmers who reported that their main reason for entering farming was to develop a business to generate income were $25.9 \%$ more likely to participate in markets than those with a different reason for entering farming. This result was expected and follows the 
Theory of Planned Behavior. Those whose initial intention was to develop a business to generate income are more likely to carry out that behavior.

It was expected that producers who believed that farming is a viable business venture would be more likely to participate in the market. However, the model illustrates that producers who believe that farming is a viable business venture are in fact $10 \%$ less likely to participate in the market than those who do not believe this. Perhaps farmers that are participating in markets are experiencing the reality of farming as a business and are therefore less likely to be inclined to think it is truly viable. Those farmers who are not yet selling perhaps perceive opportunity in markets. In either case, belief in farming as a viable business does not appear to be a prerequisite for market participation.

Whether a respondent's ancestors settled to farm was included to capture aspects of subjective norms related to lineage and culture that could influence producers' decisions. This variable was expected to positively influence the decision to participate in the market, as a long lineage of farming history might be expected to influence lifestyle and occupational choice. Contrary to our expectations, this model indicates that producers whose ancestors were associated with farming as opposed to other occupations such as mining or timbering were $8 \%$ less likely to participate in the market. That a lineage of farming might negatively impact a producer's decision to sell could be a function of the agricultural historical and cultural context of Appalachia. According to LaLone (2010), Appalachian farmers have weathered the changing economic landscape of farming as large-scale agriculture pressured smaller farms out of markets. The opportunities that local food markets present are relatively recent. Producers whose families have historical experience with farming may face influence of subjective norms that have shaped their attitudes and the attitudes of those around them in terms of perceptions of farming as a 
business venture. Families that endured the downturn of agricultural viability over the last century may be less likely to participate as commercial farmers, or are slower to accept the potential opportunity of burgeoning local food markets. Values related to self-provisioning and reciprocity might also be underlying subjective norms. A historical lineage of farming and related values might not equate to inclination to entrepreneurial- or business-mindedness about farming.

Farm-level factors such as distance to market and access to labor, or demographic factors do not appear to influence producers' decisions to participate in markets.

\section{Model 2: Sales Volume Decision}

The results of the OLS model of sales volume are presented in Table 7. The model appears to explain about a third of the variation in sales levels, indicated by an $\mathrm{R}^{2}$ value of 0.36 . The overall model was found to be significant (F statistic with p-value: $<2.2 \mathrm{e}-16$ ). A series of tests were run to ensure that the model did not violate assumptions of the linear model. A Jarque Bera Test indicated that the error terms followed the normality assumption ( $\mathrm{p}$-value $<2.2 \mathrm{e}-16$ ). A non-constant variance score test did not indicate the presence of heteroskedasticity of errors. Multicollinearity was also not detected in the model, as examined using a variance inflation factor test (vif) in R. 
Table 7. Factors influencing sales volume behavior, OLS coefficients

\begin{tabular}{|c|c|c|c|c|}
\hline Description of Variable & Estimate & $\begin{array}{l}\text { Std. } \\
\text { Error }\end{array}$ & t value & $\operatorname{Pr}(>|\mathbf{t}|)$ \\
\hline (Intercept) & $37,264.94$ & 47228.84 & 0.789 & 0.431 \\
\hline Age & -600.64 & 439.76 & -1.366 & 0.173 \\
\hline Gender & ,2085.20 & 11253.84 & 0.185 & 0.853 \\
\hline Education & $1,128.01$ & 3237.08 & 0.348 & 0.728 \\
\hline Operator works full-time off the farm & $-6,624.45$ & 11472.03 & -0.577 & 0.564 \\
\hline $\begin{array}{l}\text { Number of acres of usable agricultural } \\
\text { land to which the operator has access }\end{array}$ & 228.27 & 25.42 & 8.979 & 0.000 \\
\hline Distance to market (miles) & -192.13 & 422.98 & -0.454 & 0.650 \\
\hline $\begin{array}{l}\text { Plan to pass farm/garden on to a known } \\
\text { successor }\end{array}$ & $-17,599.43$ & 11027.95 & -1.596 & 0.111 \\
\hline $\begin{array}{l}\text { Number generations land has been in } \\
\text { family }\end{array}$ & $-9,145.33$ & 4196.90 & -2.179 & $\mathbf{0 . 0 3 0}$ \\
\hline Access to water for irrigation & $18,316.95$ & 10752.24 & 1.704 & 0.089 \\
\hline Land owned by operator & $12,673.84$ & 27355.88 & 0.463 & 0.643 \\
\hline Hired laborers & $59,352.51$ & 14493.99 & 4.095 & 0.000 \\
\hline Family laborers & -766.00 & 10512.79 & -0.073 & 0.942 \\
\hline $\begin{array}{l}\text { Percentage of diet made up of food products } \\
\text { that you raise }\end{array}$ & $-17,874.56$ & 20065.03 & -0.891 & 0.374 \\
\hline Raised fattened beef in 2012 & $-28,747.76$ & 14158.66 & -2.030 & 0.043 \\
\hline Raised broilers in 2012 & $14,813.55$ & 19633.66 & 0.754 & 0.451 \\
\hline Raised layers in 2012 & $-16,653.58$ & 12191.33 & -1.366 & 0.173 \\
\hline Raised pork in 2012 & $-2,985.11$ & 19623.90 & -0.152 & 0.879 \\
\hline Raised lamb in 2012 & $20,211.75$ & 18764.05 & 1.077 & 0.282 \\
\hline Raised meat goats in 2012 & $-21,471.85$ & 23870.47 & -0.900 & 0.369 \\
\hline Raised dairy cows in 2012 & $36,740.85$ & 26793.99 & 1.371 & 0.171 \\
\hline Raised fruit trees in 2012 & $11,621.68$ & 10247.49 & 1.134 & 0.258 \\
\hline Raised vegetables in 2012 & $13,125.98$ & 15814.76 & 0.830 & 0.407 \\
\hline People value my role as a farmer/gardener. & $-7,087.49$ & 11243.34 & -0.630 & 0.529 \\
\hline I would encourage youth to pursue farming. & $1,088.72$ & 13406.36 & 0.081 & 0.935 \\
\hline Ancestors settled to farm & $13,176.56$ & 11099.94 & 1.187 & 0.236 \\
\hline Ancestors: German & $6,394.84$ & 12307.00 & 0.520 & 0.604 \\
\hline Ancestors: Scot-Irish & $5,505.65$ & 19114.44 & 0.288 & 0.774 \\
\hline $\begin{array}{l}\text { Reason for entering farming: Take over } \\
\text { farm from family or another person }\end{array}$ & $80,280.93$ & 15818.05 & 5.075 & $\mathbf{0 . 0 0 0}$ \\
\hline $\begin{array}{l}\text { Reason for entering farming: develop } \\
\text { business to generate additional income }\end{array}$ & $-1,047.52$ & 12134.82 & -0.086 & 0.931 \\
\hline Farming is a viable business venture. & $4,494.99$ & 10874.49 & 0.413 & 0.680 \\
\hline $\begin{array}{l}\text { Household prefers to have off-farm } \\
\text { income as well to reduce risk. }\end{array}$ & $-32,254.89$ & 11230.46 & -2.872 & 0.004 \\
\hline
\end{tabular}


Access to resources appears to be associated with sales volume. Increased access to agricultural land and hired labor are positively associated with higher annual sales levels. Having access to one more acre of usable agricultural land would increase annual gross sales by $\$ 228$, and farmers who hired labor had gross sales in 2012 that were $\$ 59,353$ higher than those who did not. This is intuitive, as larger farms are likely to have more hired labor to meet production demands. Having access to water for irrigation is associated with higher annual gross sales by $\$ 18,317$ compared to those without irrigation. In terms of production enterprises the presence of fattened beef on a farm is associated with lower annual gross sales $(\$ 28,748)$ than those who did not have fattened beef.

This study indicates the influence of the income diversification attitude variable "prefers to have off-farm income to reduce risk" which is significant in this model and associated with lower annual gross farm sales of $\$ 32,255$. This is consistent with Bergevoet et al. (2004) who found that diversification of off-farm activities was associated with decreased farm size.

Producers whose main reason for entering farming was to "take over farm from family member or another person" have higher annual gross sales by $\$ 80,281$ compared to producers with other reasons for entering farming. This is likely to be because businesses that are passed down are more likely to be well-established and successful. However, an increase in one generation that a producer's land has been in her/his family is associated with lower annual sales of $\$ 9,145$. This may be due to social and cultural norms and perceptions about farming among families that have passed through changes in agriculture, as discussed in LaLone (2010). 


\section{Model 3: Market Participation Intentions among Current Non-participants}

A total of 91 producers compose the group analyzed in this model. A total of 172 producers did not sell in 2012. However, due to non-response on certain survey questions that resulted in missing values, the number of usable observations was reduced to 91 . The overall

model is significant, with goodness of fit measures being adequate; McFadden $\mathrm{R}^{2}$ was 0.679 , and a likelihood ratio test result of 48.928 had a significant chi-squared value ( $p$-value $=0.0013$ ). The results of the model estimation are presented in Table 8 . Variables that were found to be significant are in bold and coefficients and marginal effects are presented. 
Table 8. Factors influencing market participation intentions, Probit model coefficients and marginal effects

\begin{tabular}{|c|c|c|c|c|c|}
\hline Description of Variable & Estimate & $\begin{array}{l}\text { Std. } \\
\text { Error }\end{array}$ & $z$ value & $\operatorname{Pr}(>|z|)$ & $\begin{array}{l}\text { Marginal } \\
\text { Effects }\end{array}$ \\
\hline (Intercept) & -0.63 & 2.84 & -0.22 & 0.824 & -0.147 \\
\hline Age & 0.00 & 0.02 & 0.04 & 0.965 & 0.000 \\
\hline Distance to market (miles) & 0.05 & $\mathbf{0 . 0 3}$ & 1.77 & 0.077 & 0.013 \\
\hline Educational Attainment & -0.14 & 0.15 & -0.94 & 0.346 & -0.033 \\
\hline Household Income & -0.08 & 0.06 & -1.25 & 0.210 & -0.018 \\
\hline Operator works full-time off the farm & 1.34 & 0.57 & 2.35 & 0.019 & 0.312 \\
\hline Gender & 0.17 & 0.41 & 0.42 & 0.675 & 0.040 \\
\hline $\begin{array}{l}\text { Reason for entering farming: take over farm } \\
\text { from family member or another person }\end{array}$ & -0.49 & 0.57 & -0.86 & 0.389 & -0.114 \\
\hline $\begin{array}{l}\text { Reason for entering farming: develop business } \\
\text { to generate additional income }\end{array}$ & 0.89 & 0.98 & 0.91 & 0.364 & 0.208 \\
\hline Attitude: Farming is a viable business venture & -0.78 & 0.49 & -1.60 & 0.111 & -0.183 \\
\hline $\begin{array}{l}\text { Attitude: Prefer to have off-farm income to } \\
\text { reduce risk }\end{array}$ & 0.36 & 0.46 & 0.79 & 0.432 & 0.084 \\
\hline Percentage of diet raised on farm & 1.27 & 0.94 & 1.35 & 0.178 & 0.295 \\
\hline $\begin{array}{l}\text { Number acres agricultural land to which } \\
\text { operator has access }\end{array}$ & $\mathbf{0 . 0 0}$ & $\mathbf{0 . 0 0}$ & 1.80 & 0.071 & 0.001 \\
\hline Not interested in selling; just a hobby & -0.38 & $\mathbf{0 . 2 3}$ & -1.67 & 0.095 & -0.089 \\
\hline Used to sell but now retired & 0.26 & 0.20 & 1.33 & 0.184 & 0.061 \\
\hline $\begin{array}{l}\text { Prefer to give away extra produce rather than } \\
\text { sell it }\end{array}$ & -0.01 & 0.22 & -0.03 & 0.975 & -0.002 \\
\hline $\begin{array}{l}\text { Afraid of consequences if product makes } \\
\text { someone sick }\end{array}$ & 0.61 & $\mathbf{0 . 2 3}$ & 2.66 & 0.008 & 0.141 \\
\hline Complicated regulations & -0.39 & 0.24 & -1.60 & 0.110 & -0.091 \\
\hline Pest and Disease problems & 0.12 & 0.20 & 0.59 & 0.557 & 0.028 \\
\hline Too far to sell at a profitable market outlet & 0.49 & 0.25 & 1.97 & 0.049 & 0.113 \\
\hline Don't have the time to sell & -0.61 & 0.24 & -2.52 & $\mathbf{0 . 0 1 2}$ & -0.143 \\
\hline Difficulty hiring type of labor needed & -0.06 & 0.20 & -0.30 & 0.763 & -0.014 \\
\hline Believe it wouldn't be profitable & -0.53 & 0.26 & -2.06 & $\mathbf{0 . 0 3 9}$ & -0.124 \\
\hline Lack of demand in local markets & 0.45 & 0.30 & 1.51 & 0.131 & 0.105 \\
\hline
\end{tabular}

The distance to market and number of acres of usable agricultural land that the operator has access to have small but significant positive impacts on the intention to participate in the market in the future. Increased distance of one mile increased the likelihood of a producer being 
interested in selling by $1 \%$. This is counterintuitive, as we would expect that increased distance would increase transaction costs and reduce interest in selling. This unexpected result may also be due to small sample size. However, this result indicates that distance to market is not a barrier inhibiting entry of interested producers to the market. Understanding this result requires further investigation into the nature of this variable and its relationship to marketing intentions.

Producers that reported working full-time off the farm were $31 \%$ more likely to be interested in participating in a marketing channel within the next two years. One might expect full time work to decrease intentions to sell because a producer would be busy. However, this result indicates interest among producers that work off-the-farm in dedicating more attention to earning income from their farm. This might indicate that they perceive new opportunities in local food markets. It was expected that age of operator would have a negative relationship with interest in market participation but this coefficient was not significant.

Producers with access to greater acreage of usable agricultural land were more likely to indicate intentions to participate in a market channel within the next two years, although the marginal effect was small, a less than $1 \%$ increase in likelihood of intending to market. This could reflect a shift in thinking about land use among landowners with available acreage that recognize new market opportunities.

Several factors related to perceived behavioral control and attitudes influence intentions to participate in markets. Reporting that being too far from a profitable market was a reason they did not sell in 2012 increased the likelihood that a producer intends to sell within the next two years by about $11 \%$. Considering that the variable "distance to market" was also associated with the intention to sell in the future suggests that distance may not be limiting the intended market 
participation of some producers, even if, as indicated here, they thought it was a barrier in the past. Perhaps the growth in demand for local products, or emergence of aggregation and distribution opportunities, has convinced some producers to sell their products in the future even though distance may have discouraged them in the past.

Producers that indicated they did not sell in 2012 because they were concerned about food safety were $14 \%$ more likely to indicate future intentions to participate in a market. This indicates that for some reason these producers no longer are concerned about causing a food safety problem. Perhaps they have received (or intend to receive) training in good handling practices so that they can sell in the future with confidence.

Producers who believe that selling their food products would not be profitable are $12 \%$ less likely to have intentions to sell in the next two years. Producers who indicated that they do not have time to sell their food products are $14 \%$ less likely to have intentions to sell their products in the next two years. Apparently these past barriers are difficult to overcome and producers who do not have time or do not see any potential profitability will not change their minds in the next 2 years, unless those conditions and perceptions can be changed. If these producers believed that selling their products could be profitable, they might consider entering the market.

\section{Model 4: Factors that Influence the Intention to Expand Food Production}

The model is assumed to be significant overall, as goodness of fit measures are adequate, with a McFadden $\mathrm{R}^{2}$ of 0.494 and a likelihood ratio test result of 89.49 for which the chi-squared value was significant $(\mathrm{p}=2.414 \mathrm{e}-07)$. Table 9 presents probit model results, including coefficients and marginal effects. Variables that were significant (p-value <0.10) are in bold. 
Table 9. Factors Influencing Expansion Intentions, Probit Model Coefficients and Marginal Effects

\begin{tabular}{|c|c|c|c|c|c|}
\hline Description of Variable & Estimate & $\begin{array}{l}\text { Std. } \\
\text { Error }\end{array}$ & $z$ value & $\operatorname{Pr}(>|z|)$ & $\begin{array}{l}\text { Marginal } \\
\text { Effects }\end{array}$ \\
\hline (Intercept) & -1.53 & 2.08 & -0.73 & 0.463 & -0.458 \\
\hline Age & -0.03 & 0.01 & -3.34 & 0.001 & -0.008 \\
\hline Gender & 0.86 & $\mathbf{0 . 2 0}$ & 4.24 & 0.000 & 0.258 \\
\hline Education & -0.13 & 0.06 & -2.19 & 0.028 & -0.039 \\
\hline Household Income & 0.00 & 0.02 & 0.11 & 0.912 & 0.001 \\
\hline Operator works full-time off the farm & 0.15 & 0.19 & 0.79 & 0.427 & 0.046 \\
\hline $\begin{array}{l}\text { Number of acres of usable agricultural land } \\
\text { to which the operator has access }\end{array}$ & 0.00 & 0.00 & 0.73 & 0.467 & 0.000 \\
\hline Distance to market (miles) & 0.00 & 0.01 & -0.68 & 0.499 & -0.001 \\
\hline $\begin{array}{l}\text { Plan to pass farm/garden on to a known } \\
\text { successor }\end{array}$ & 0.76 & 0.20 & 3.86 & 0.000 & 0.227 \\
\hline $\begin{array}{l}\text { Number of generations land has been in } \\
\text { family }\end{array}$ & -0.05 & 0.07 & -0.78 & 0.438 & -0.016 \\
\hline Access to water for irrigation & 0.38 & 0.19 & 1.99 & 0.047 & 0.115 \\
\hline Land owned by operator & -0.87 & 0.69 & -1.25 & 0.210 & -0.261 \\
\hline Hired laborers & 0.05 & 0.25 & 0.21 & 0.832 & 0.016 \\
\hline Family laborers & -0.43 & 0.19 & -2.35 & 0.019 & -0.130 \\
\hline $\begin{array}{l}\text { Percentage of diet made up of food } \\
\text { products that you raise }\end{array}$ & -0.90 & 0.34 & -2.63 & 0.008 & -0.270 \\
\hline Raised fattened beef in 2012 & 0.20 & 0.25 & 0.79 & 0.428 & 0.059 \\
\hline Raised broilers in 2012 & 0.33 & 0.35 & 0.95 & 0.343 & 0.100 \\
\hline Raised layers in 2012 & 0.12 & 0.21 & 0.55 & 0.582 & 0.035 \\
\hline Raised pork in 2012 & 0.19 & 0.36 & 0.54 & 0.589 & 0.058 \\
\hline Raised lamb in 2012 & 0.13 & 0.30 & 0.43 & 0.666 & 0.039 \\
\hline Raised meat goats in 2012 & 0.46 & 0.49 & 0.93 & 0.350 & 0.137 \\
\hline Raised dairy cows in 2012 & 0.04 & 0.44 & 0.09 & 0.930 & 0.011 \\
\hline Raised fruit trees in 2012 & 0.10 & 0.18 & 0.55 & 0.580 & 0.029 \\
\hline Raise vegetables in 2012 & 0.11 & 0.26 & 0.44 & 0.661 & 0.034 \\
\hline People value my role as a farmer/gardener. & -0.04 & 0.20 & -0.22 & 0.824 & -0.013 \\
\hline I would encourage youth to pursue farming. & 0.29 & 0.24 & 1.24 & 0.216 & 0.088 \\
\hline Ancestors settled to farm & 0.01 & 0.19 & 0.05 & 0.962 & 0.003 \\
\hline Ancestors: German & -0.06 & 0.21 & -0.30 & 0.766 & -0.019 \\
\hline Ancestors: Scot-Irish & 0.10 & 0.34 & 0.29 & 0.774 & 0.029 \\
\hline $\begin{array}{l}\text { Reason for entering farming: Take over } \\
\text { farm from family or another person }\end{array}$ & 0.09 & 0.27 & 0.32 & 0.753 & 0.026 \\
\hline $\begin{array}{l}\text { Reason for entering farming: develop } \\
\text { business to generate additional income }\end{array}$ & 0.35 & 0.20 & 1.70 & 0.090 & 0.104 \\
\hline Farming is a viable business venture. & 0.13 & 0.19 & 0.69 & 0.490 & 0.040 \\
\hline $\begin{array}{l}\text { Household prefers to have off-farm income } \\
\text { as well to reduce risk. }\end{array}$ & 0.13 & 0.20 & 0.66 & 0.512 & 0.039 \\
\hline
\end{tabular}


Farm-level factors related to access to resources increase likelihood of plans to expand. Producers with access to water for irrigation are $12 \%$ more likely to intend to expand than those without irrigation. This is expected since expansion incurs greater resource needs and a level of formality that requires that producers seek the means to care for crops, such as by irrigating rather than relying on rain alone. Interestingly, producers with access to family labor are $13 \%$ less likely to say they will expand. Perhaps producers with family laborers are at capacity or are not intent on working harder to expand. Access to hired labor did not appear to impact the intention to expand. Producers who plan to pass off the farm to a known successor are $23 \%$ more likely to indicate they will expand. This is consistent with O'Donnell, et al. (2011) who found that succession plans significantly influenced expansion goals.

Several sociodemographic characteristics of producers significantly influenced expansion intentions. As expected, increased age is associated with decreased likelihood of intention to expand, albeit small $(<1 \%)$. Higher educational attainment was associated with a $4 \%$ decrease in likelihood of expansion intention. Expansion would be associated with greater time dedicated to farming or gardening and away from other activities. People with more education may have greater access to other income opportunities that would predispose them to restrict their gardening or farming time commitment. Females were $26 \%$ more likely to have intentions to expand than males.

Interestingly, the percentage of diet that producers raise was significantly and negatively associated with intentions to expand. As the percentage of diet made up of food products raised by the producer increases by $1 \%$ the likelihood of wanting to expand decreases by $27 \%$. This could be related to producer goals. If self-sufficiency is important, if dietary needs are met, a 
producer may be not interested in expanding. This variable may therefore reflect the impact of goals related to self-sufficiency that could reduce likelihood of significant expansion for markets.

Producers whose reason for entering farming was to develop a business to generate additional income are $10 \%$ more likely to intend to expand. This reason is related to what Gasson (1973) would classify as instrumental or economic values related to farming. It is expected that producers motivated by income generation would intend to expand production for markets. The factors found to be significant in this model are related to economic rather than non-economic factors. This is consistent with Bergevoet et al. (2004) who found that economic factors were most important influencers of expansion plans. 


\section{Summary of Findings}

Table 10. Summary of impact of variables on market participation and expansion intentions (direction of influence of significant variables)

\begin{tabular}{|c|c|c|c|c|}
\hline \multirow[b]{2}{*}{ Variable } & \multicolumn{2}{|c|}{ Influence on behavior } & \multicolumn{2}{|c|}{ Influence on intentions } \\
\hline & $\begin{array}{c}\text { Market } \\
\text { participation } \\
\text { among all } \\
\text { producers }\end{array}$ & $\begin{array}{c}\text { Sales } \\
\text { volume } \\
\text { levels } \\
\text { among } \\
\text { producers } \\
\text { that } \\
\text { currently } \\
\text { sell } \\
\end{array}$ & $\begin{array}{c}\text { Market } \\
\text { participation } \\
\text { intentions } \\
\text { among } \\
\text { producers } \\
\text { that do not } \\
\text { currently } \\
\text { sell }\end{array}$ & 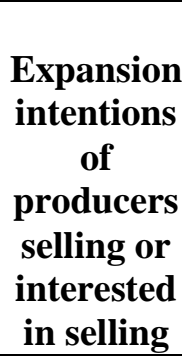 \\
\hline Educational Attainment (7 possible levels) & & & & $(-)$ \\
\hline Age & & & & $(-)$ \\
\hline Gender & & & & $(+)$ \\
\hline $\begin{array}{l}\text { Number of acres of agricultural land available to } \\
\text { operator }\end{array}$ & & $(+)$ & $(+)$ & \\
\hline Work full time off the farm (yes $=1$ ) & & & $(+)$ & \\
\hline Distance to market (miles) & & & $(+)$ & \\
\hline Access to water for irrigation (yes $=1$ ) & & $(+)$ & & $(+)$ \\
\hline Family laborers (yes $=1$ ) & & & & $(-)$ \\
\hline Hired laborers (yes $=1$ ) & & $(+)$ & & \\
\hline $\begin{array}{l}\text { Plan to pass farm/garden on to a known successor } \\
(\text { Agree=1) }\end{array}$ & & & & $(+)$ \\
\hline $\begin{array}{l}\text { Percentage of diet made up of food products that } \\
\text { you raise }\end{array}$ & $(+)$ & & & $(-)$ \\
\hline Raised broilers in 2012 (yes $=1$ ) & $(+)$ & & & \\
\hline Raised beef cows in 2012 (yes=1) & & $(-)$ & & \\
\hline Raised vegetables in 2012 (yes=1) & $(-)$ & & & \\
\hline $\begin{array}{l}\text { Reason for Entering Farming: Develop business } \\
\text { to generate additional income (yes }=1 \text { ) }\end{array}$ & $(+)$ & & & $(+)$ \\
\hline $\begin{array}{l}\text { Reason for Entering Farming: Take over farm } \\
\text { from family member or another person (yes }=1 \text { ) }\end{array}$ & & $(+)$ & & \\
\hline Farming is a viable business venture & $(-)$ & & & \\
\hline $\begin{array}{l}\text { My household prefers to have off-farm income as } \\
\text { well to reduce risk. (Agree }=1 \text { ) }\end{array}$ & & $(-)$ & & \\
\hline Ancestors settled to farm (yes $=1)$ & $(-)$ & & & \\
\hline Number of generations farm in family & & $(-)$ & & \\
\hline $\begin{array}{l}\text { Concerned about consequences if products made } \\
\text { someone sick }\end{array}$ & & & $(+)$ & \\
\hline Distance to profitable market is too far & & & $(+)$ & \\
\hline No time to produce/market products & & & $(-)$ & \\
\hline Would not be profitable to sell products & & & $(-)$ & \\
\hline Not interested in selling; just a hobby & & & $(-)$ & \\
\hline
\end{tabular}




\section{CHAPTER 5: CONCLUSIONS AND IMPLICATIONS}

The results of this study suggest the importance of attitudes, subjective norms, and perceived behavioral control in analysis of market participation and supply response behavior and intentions. Here important factors are highlighted and implications for development work, limitations, and areas for future research are presented.

\section{Factors that influence supply response behavior and intentions}

Market participation is regarded as a decision that is influenced by non-economic factors, whereas sales volume is influenced primarily by economic factors (Angula, 2010). The results of the market participation model are consistent with this literature; significant variables are related to non-economic factors such as motivation for entering farming, attitudes, and subjective norms. While the sales volume decision was influenced by farm-level factors related to resource availability, the influence of motivational and attitudinal factors as well as subjective norms is also present.

Intentions to participate in markets in the future were not found to be influenced by what could be considered barriers, such as access to land, full-time off-farm employment, and distance to market. Results also illustrate the influence of attitudes related to perception of profitability that could be limiting producer market participation, while previous barriers related to perceived behavioral control, such as concern over food safety, may not limit future producer market participation.

While factors related to subjective norms and motivation overtly influenced supply response behavior, they appeared to be less influential on the expansion intensions of producers. Factors that influenced expansion intentions were primarily related to producer socioeconomic 
and farm-level characteristics, including access to resources and the presence of a successor. This study identifies farm succession as an important factor related to market participation and supply volume behavior and intentions. This is consistent with previous research that has also found the existence of a successor to be positively associated with expansion intentions (O’Donnell et al., 2011). The importance of succession may be due to having an established resource base or to enhanced perceived behavioral control and positive subjective norms towards farming.

Producer motivation influences expansion intentions. A greater association with instrumental goals, as reflected in the reason for entering farming being to develop a business to generate income, increases the likelihood of intending to expand. Conversely, an increased percentage of the household's diet raised on the farm (ostensibly associated with higher selfsufficiency goals) decreases this likelihood.

The importance of subjective norms is also salient. Producers that have ancestors that farmed were less likely to participate in the market. This variable was included to identify whether cultural heritage and lineage influence producers' decisions by means of impacting the subjective norms that influence producers' attitudes and intentions. LaLone (2010) discussed how Appalachian farm families have weathered and adapted to changing agricultural conditions and economies. Perceptions of agriculture that have been passed down over generations could potentially influence producers now. For example, families that regard farming as a worthy lifestyle but not a viable occupation could influence the opinions of producers and potentially make them less likely to participate in markets. This variable appears to reflect the influence of subjective norms related to social and cultural influence. 
LaLone (2010) identified income stream diversification as one of the three adaptive strategies that Appalachian farm families have used to adjust to changing economic and agricultural landscapes over the past century. The importance of this characteristic was found in our quantitative study as well. Producers reporting that they preferred to have off-farm income to diversify risk had lower sales levels. We can only conclude that there is a relationship between this diversification attitude and lower sales but we cannot infer causality. For example, do people that are more risk averse hold this attitude and therefore remain at low sales levels because they have diverse income streams and are not fully dedicated to farming? From a profit-maximizing perspective, one might conclude that the higher sales levels of producers that did not articulate this desire to diversify reflect a more profit-maximizing orientation. Alternatively, do low sales levels mean that producers must have this attitude to diversify to get by? While this tendency to diversify to reduce risk did not appear to significantly impact market participation behavior or intentions, or expansion intentions, it did influence sales volume. Therefore, this factor could limit supply levels in local markets.

Interestingly, producers that agreed that farming is a viable business venture were less likely to sell. Reflecting on those participating in markets, one might conclude that believing in the viability of the enterprise is not a prerequisite for engaging in it. Preference for off-farm work that is associated with lower sales, and doubt about the viability of farming as a business enterprise among producers selling their products would suggest a complex attitude towards farming as a business. Gasson (1973) highlights the over-simplification of economic models of producer decision making conceived as profit maximization. She cites the fact that many producers have occupations off the farm and asks the pointed question "does profit maximization for them refer to the farm, the other business, or the two in conjunction?" (523) emphasizing the 
complex nature of farmer decision making and goals. Perhaps producers are not trying to maximize profits, but rather diversify income sources for economic resilience. That income diversification is important would be consistent with LaLone's (2010) qualitative analysis of Appalachian farm families.

\section{Implications for Rural Development Work and Practice}

\section{Potential new entrants as a focus of rural development efforts and increased supply}

An original premise of this study was that local food supply could grow either through expansion among current producers or entry of new producers to the market. We explored what factors would influence both of those possibilities and how this information can inform rural development efforts to bolster both expansion and new market participation.

Using a stated intentions approach, this study explored the group of non-market participants to understand the difference between those producers who could be interested in selling in the future and those who are not. Analysis of producers' intentions to participate in the market, in addition to analysis of their current behavior, allows identification of the possibility of future supply increase and the factors that influence producers. There is evidence to suggest that supply could increase through the entry of new market participants. In this study, 172 producers reported that they raised but did not sell food products in 2012 , or rather, have not made the market participation decision. Examining their intentions we identify their potential impact on food supply in the market and identify factors that could potentially mediate whether those intentions are acted upon. Of those 172 producers, almost half (47\% and 82 producers) indicated that they plan to sell through at least one market channel within the next two years. This indicates that the potential for new market participants to increase the supply of local food is plausible. 
The result that producers who believe that farming is a viable business venture decreases the likelihood that a producer will participate in markets offers perhaps more questions than answers but flags a perception about local food markets among producers. If producers participating in the market are not necessarily in agreement that farming is a viable business venture, does this mean that their goals are not related to financial viability? If their goals are related to other values, how can development interventions address those goals in a way that will make them more profitable as well? To what extent does this reflect a reality that farming is not a viable business venture for producers or to what extent does it reflect a perception influenced by subjective norms? To the extent that it has been a reality, the development of marketing models to connect producers to more viable markets would be beneficial. This is based on the assumption that demand does exist. To the extent that it is a perception, careful work to build confidence in these connections would be needed to overcome the attitudinal barriers and social perceptions or subjective norms. Other efforts to educate producers about demand for their products and facilitate market access in a way that is sensitive to risk-aversion and cultural perceptions about farming would be beneficial. Further exploration may be needed to understand how producers perceived the phrase "viable business".

Producers who work off of the farm full-time and have greater access to agricultural land have intentions to participate in the market. Producers with access to agricultural land may be interested in using their land to take advantage of a perceived opportunity in local food markets. Increased access to such resources increases not only their actual ability to take on such enterprises but also increases their perceived behavioral control and is therefore likely to increase their intentions to engage in market participation. This may indicate opportunities to facilitate market participation. Producers with access to agricultural land may need assistance in making 
land use decisions and developing business plans to take on new agricultural enterprises. Other barriers or lack of skills may exist that inhibit producers with access to land from entering markets.

Interest among people working full-time off of the farm could indicate a shift in perception of local markets as a potential new source of income-generation. It could also indicate that full-time work has inhibited the ability of these producers to act on their intentions to enter the market. Efforts to ease the entry into local food markets among producers who work fulltime jobs would be an opportunity to increase market participation and supply in local food markets. For example, collective marketing and aggregation models among producers that would work with their schedules could be helpful.

The factors that deterred market participation among those producers who do not participate in the market, but have intentions to participate in the future offer potential insight. Reasons for not selling related to food safety concerns and distance to profitable markets were significantly associated with increased likelihood of intentions to sell. Practitioners might find these to be important areas of focus in order to facilitate the participation in the market of those who are potential participants. Food safety concerns could be addressed by training, empowering, and assisting producers to implement food safety practices on their farms in addition to general education on food safety risk, but also has implications for legislation and potential regulations such as the Food Safety Modernization Act (FDA, 2013). These efforts could build producers' sense of behavioral control and actual skills which would potentially increase their likelihood of acting on their intentions to participate in the market. 
That producers who identified distance to profitable markets as a reason they did not sell in 2012 are interested in selling in the future also indicates a barrier to market participation that can be overcome. An opportunity exists to facilitate market participation among these producers by exploring ways to reduce the distance to profitable markets through collective marketing models that allow producers to aggregate small volumes of product locally and market it to more profitable markets that may be at a distance that would be cost-prohibitive for them to market in directly as individuals. For example, efforts to aggregate product in rural areas and collectively market to areas of greater population density could help overcome a belief that local markets are not profitable. This could encourage new producers who do not currently sell to participate.

\section{Expanding producers}

Since increased age reduces likelihood of intentions to expand and being female increases the likelihood of intending to expand, interventions that target youth and female farmers are likely to be more effective in increasing the supply of food in local markets. This study also suggests that producers with lower educational levels are more likely to intend to expand. Therefore, outreach and interventions about market opportunities must be targeted to reach lower educational levels.

Having access to resources such as irrigation water is associated with both higher sales levels and having the intention to expand. Having access to more acres of agricultural land and hired labor is also associated with higher sales. That access to resources is associated with greater volume suggests that traditional efforts to eliminate resource barriers and facilitate access to resources such as land and irrigation infrastructure are well-directed. Facilitating access to hired labor may also be a potential way to increase volume of sales and encourage expansion, such as through internship programs. 
Considering that having a known successor is associated with intentions to expand and inheritance of farm from family or another person is associated with higher sales levels, efforts to assist farmers to plan for generational transitions may also be a significant leverage point to increasing sales and supply.

However, these efforts to overcome barriers between intentions and behavior may encourage expansion, but we must also recall the importance of factors such as risk and diversification attitudes and subjective norms that influence sales volume. In their study applying the Theory of Planned Behavior to farm diversification decisions, Hansson et al. (2012) provide useful examples to illustrate the value of considering psychological factors in models of farmer decision-making. The authors discuss how farmers are known to be risk averse, adopting new techniques and ideas slowly in stages before fully investing. The authors discuss how interventions targeted to reduce risk, such as direct investment in farmers, may not be effective in isolation if subjective norms and attitudes and behavioral control are not addressed. They give examples of how supporting networking and highlighting success stories could help overcome the influence that such constructs might have on an individual.

To increase business viability, it is necessary to pursue ways to not only facilitate expansion of production, but also build opportunities and enhance business skills in a way that enables increased profitability while working within the context of prevalent subjective norms and attitudes. For example, if income diversification is an important value in the cultural and historical context, it may be important to develop marketing and aggregation models that ease the gradual entry of risk-averse producers. Tailoring development efforts to the values of producers is paramount to increasing supply of local food. 


\section{Limitations}

It is not possible to generalize about $\mathrm{WV}$ farmers based on this study due to potential bias in the sample population. The sample was generated based on networks of WVU Extension staff and farmers market managers who were likely to have connections to producers in the local food system. However, it cannot be assumed that all local food producers are represented among these networks and in this sample. There are likely to be producers that could potentially intend to participate in markets who are not associated with service provider networks. Obtaining the contact information for these producers is difficult and not within the scope of this study.

Furthermore, the sample size is small compared to the over 23,000 farmers in WV. The sample may also be biased based on compilation of lists provided to researchers. For example, lists from several counties appeared to be inclusive of all contacts, whereas lists from other counties represented only farmers market vendors. The sample also lacked representation from the southern part of the state and northern panhandle. A spatial analysis component could be beneficial in this study to analyze the impact of potential geographic spillover effects.

Inquiry into intentions regarding expansion scale and direction were limited by nonresponse. The survey questionnaire included questions about projected increases in production, scale, and sales goals for 2014. Many producers skipped these questions. This could be because they were not sure about their future scale. The collection of data about household size would also have enhanced the study, as we expect that is an influencing factor with regard to the decision to market products as opposed to keeping them for home consumption. With that data it would have been possible to calculate area of vegetable cultivation necessary for a given level of self-sustenance of a household, since operators reported the percentage of their diet that they produce. Furthermore, the application of a two-step sequential decision making model such as 
the double hurdle model would have perhaps leant different insight into these decisions, however, our use of attitudinal characteristics complicated this application. Factor analysis may have been a useful mechanism for understanding the relative importance of the different elements of the Theory of Planned Behavior for each decision. The inclusion of specific statements was a more crude but efficient manner of obtaining insight on these elements.

Another limitation may be related to how producers interpreted the attitudinal statements used in the survey questionnaire. The survey questionnaire was pre-tested and developed using producer feedback. However, it may have been valuable to include specific conversation about how they interpreted each attitudinal statement. This could have been improved by the use of more extensive qualitative research techniques that delve into how different concepts and language are interpreted by producers. This could be an area for future qualitative work.

\section{Academic contribution and future research}

This study demonstrates the importance of consideration of non-economic and potential cultural factors related to the Theory of Planned Behavior in models of producer decision making. This study also expands on market participation and local food markets literature to test validity of the consideration of market entry and participation in analysis of supply response in local food markets. Examining market participation and intentions to participate in this framework enabled the detection of factors that have important implications for supply response, such as the impact of diversification and low levels of belief in farming as a viable business venture among producers in the market, and detection of the impact of specific barriers limiting market entrants such as concerns about food safety and distance to market. 
This study illustrates the importance of cultural values and subjective norms that influence producer decisions and ultimately the level of supply of local food. Further inquiry into the nature of these values and norms and their impact on producers' attitudes and behavior would be beneficial. This information could lead to more specific recommendations on development efforts and interventions that could be more effectively tailored to the values of local producers. Similarly, research on how attitudes, subjective norms, and perceived behavioral control relate to producers' intentions and behavior in different marketing models would be useful. For example, do certain models appeal to different values? Anecdotally, in some WV communities, people are uncomfortable selling to their neighbors and prefer to give food away rather than attend the local farmers market. This aspect of values and subjective norms, referred to as reciprocity by LaLone (2010) was not captured in this study. Information about how different marketing models, such as farmers markets, CSAs, online markets, and wholesale brokering or cooperative efforts, are perceived or adopted within the context of these social and psychological factors could help guide the design of interventions that would effectively promote rural income generation in culturally appropriate ways. 


\section{REFERENCES}

Adams D.C., and A.E. Adams. (2008). Availability, Attitudes and Willingness to Pay for Local Foods: Results of a Preliminary Survey, Paper prepared presented at the American Agricultural Economics Association annual meeting, Orlando FL, 27-29 August.

Angula, M.N. (2010). Determinants of sustainable coffee marketing channel choice and supply response among organic and UTZ certified smallholder farmers: evidence from Uganda. Thesis, M.S. Agricultural, Food, and Resource Economics. Michigan State University.

Ajzen, I. (1991). The theory of planned behavior, Organizational Behavior and Human Decision Processes, 50(2) , 179-211.

Bartolini, F., and Viaggi, D. (2011). Factors affecting the impact of CAP scenarios on farm structure: an analysis based on stated intentions. Paper prepared for presentation at the EAAE 2011 Congress Change and Uncertainty, Zurich, Switzerland, August 30September 2, 2011.

Bergevoet, R., Ondersteijn, C., Saatkamp, H., Woerkum, C., and Huirne, R. (2004). Entrepreneurial behavior of dutch dairy farmers under a milk quota system: goals, objectives, and attitudes. Agricultural Systems, 80, 1-21.

Berkhout, A.D., Schipper, R.A., Kuyvenhoven, A., Coulibaly, O. (2010). Does heterogeneity in goals and prefences affect efficiency? A case study of farm households in northern Nigeria. Agricultural Economics, 41, 265-273.

Bessant, K.C. (2000). Part-time Farming Situations among Manitoba Farm Operators: A Typological Approach. Canadian Journal of Agricultural Economics, 48, 259-277. 
Brown, C., Gandee, J.E., D’Souza, G. (2006). West Virginia Farm Direct Marketing: A County Level Analysis, Journal of Agricultural and Applied Economics, 38(3), 575-584.

Brown, C., Miller, S., Boone, D., Boone, H., Gartin, S., and McConnell, T. (2007). The importance of farmers' markets for West Virginia direct marketers. Renewable Agriculture and Food Systems, 22(1), 20-29.

Cragg, G.J. (1971). Some statistical models for limited dependent variables with application to the demand for durable goods, Econometrica, 39 (5), 829-844.

Detre, J.D., Mark, T.B., Mishra, A.K., and Adhikari, A. (2011). Linkage between direct marketing and farm income: A double-hurdle approach. Agribusiness, 27(1), 19-33.

Dillman, D.A. (2000). Mail and Internet Surveys: The tailored design method ( $2^{\text {nd }} e d$.). New York: John Wiley \& Sons, Inc.

Dunne, J., Chambers, K., Giombolini, K., Schlegel, S. (2010). What Does "Local" Mean in the Grocery Store? Multiplicity in Food Retailers' Perspectives on Sourcing and Marketing Local Foods. Renewable Agriculture and Food Systems, 26(1), 46-59.

Durham, C., King, R., and Roheim, C. (2009). Consumer Definitions of 'Locally Grown' for Fresh Fruits and Vegetables, Journal of Food Distribution Research, 40, 56-62.

Edwards-Jones, G. (2006). Modelling farmer decision-making: concepts, progress, and challenges. Animal Science,82: 783-790.

Feagan, R. (2007). The Place of Food: Mapping Out the 'Local' in Local Food Systems. Progress in Human Geography, 31(1), 23-42. 
Fielding, K., Terry,D., Masser, B., and Hogg, M. (2008). Integrating social identity theory and the Theory of Planned Behavior to explain decisions to engage in sustainable agricultural practices. British Journal of Social Psychology, 47,23-48.

Florkowski, W.J., and Bilgic, A. (2000). Planning an expansion of blueberry production by southern growers. Selected paper presented at Southern Agricultural Economics Association Annual Meetings, Orlando, Florida, February 5-8, 2006.

Garforth, C., and Rehman, T. (2005). Review of literature on measuring farmers' value, goals and objectives, Research Project EPES 0405/17. University of Reading.

Gasson, R. (1973). Goals and values of farmers, Journal of Agricultural Economics, 24, 521542.

Gillespie, J. and Mishra, A.(2011) Off-farm employment and reasons for entering farming as determinants of production enterprise selection in US agriculture, Australian Journal of Agricultural and Resource Economics, 55, 411-428.

Gujarati, D. (2011). Econometrics by Example. Palgrave Macmillan: NY.

Hand, M., and Martinez, S. (2010). Just What Does Local Mean? Choices Magazine, 25(1).

Hansson, H., Ferguson, R., and Olofsson, C. (2012). Psychological Constructs Underlying Farmers' Decisions to Diversify or Specialise their Businesses - An Application of Theory of Planned Behaviour. Journal of Agricultural Economics, Vol. 63, No.2, 2012, $465-482$. 
Hartz, L., Eades, D., Brown, C., McConnell, T., Hereford, A., and Boettner, F. (2012). West Virginia Food System: seasonal production expansion and its impacts. A Report by Downstream Strategies.

Heckman, J.J. (1979). Sample selection bias as a specification error. Econometrica, 47(1), 153161.

Higuchi, A., Moritaka, M., Susumu, F. (2012). The impact of socio-economic characteristics on coffee farmers' marketing channel choice: Evidence from Villa Rica, Peru. Sustainable Agriculture Research, 1(1), 13-18.

Hinrichs, C. (2000) Embeddedness and Local Food Systems: Notes on Two Types of Direct Agricultural Market, Journal of Rural Studies, 16, 295-303.

Hu, W., Batte, M., Woods, T., and Ernst, S. (2012). Consumer Preferences for Local Production and Other Value-Added Label Claims for a Processed Food Product. European Review of Agricultural Economics, 39 (3), 489-510.Hu,

Hu, W., T. Woods, and S. Bastin. (2009). “Consumer Acceptance and Willingness to Pay for Blueberry Products with Nonconventional Attribute.” Journal of Agricultural and Applied Economics 41(1):47-60.

Hu, W., M.T. Batte, T. Woods, and S. Ernst. (2010). What is Local and for What Foods Does it Matter?, Paper presented at the Southern Agricultural Economics Association annual meeting, Orlando FL, 6-10 February. 
Hughes, D.W., Brown, C., Miller, S., and McConnell, T. (2008). Evaluating the Economic Impact of Farmers' Markets Using an Opportunity Cost Framework. Journal of Agricultural and Applied Economics, 40(1), 253-265.

Ilbery, B., and Maye, D. (2006) Retailing Local Food in the Scottish-English Borders: A Supply Chain Perspective, Geoforum, 37, 352-367. (In Martinez, et al. 2010).

Jari, B., and Fraser, G.C.G. (2009). An analysis of institutional and technical factors influencing agricultural marketing amongst smallholder farmers in the Kat River Valley, Eastern Cape Province, South Africa, African Journal of Agricultural Research, 4(11), 11291137.

LaLone, M.B. (2010). Running the Family Farm: Accommodation and Adaptation in an Appalachian Region. Journal of Appalachian Studies, 14(1,2), 62-98.

Lahtinen, L., Vare, M. (2011). The consolidation phase: Survival strategies of farmers stabilizing and developing their businesses. Paper prepared for presentation at the EAAE 2011 Congress Change and Uncertainty Challenges for Agriculture, Food and Natural Resources, ETH Zurich, Zurich, Switzerland August 30 to September 2.

Long, A. (2011). The Politics of Self-provisioning in North-central West Virginia. Thesis, MA, Department of Geology and Geography, West Virginia University.

Low, S., and Vogel, S. Direct and Intermediated Marketing of Local Food in the United States, ERR 128, U.S. Department of Agriculture, Economic Research Service, November 2011.

Maddala, G.S. (1983). Limited Dependent and Qualitative Variables in Econometrics. NY: Cambridge University Press. 
Martinez, S., Hand, M., Da Pra, M., Pollack, S., Ralston, K., Smith, T., Vogel, S., Clark, S., Lohr, L., Low, S., and Newman, C. (2010). Local Food Systems: Concepts, Impacts, and Issues, ERR 97, Economic Research Service, US Department of Agriculture.

Meas, T., Hu, W., Batte, M., Woods, T., and Ernst, S. (2013). "Local is the New Organic": Do Consumers Agree? Selected Paper, Agricultural and Applied Economics Association's 2013 AAEA and CAES Joint Annual Meeting, Washington. DC, August 4-6, 2013.

O’Donnell, S., Horan, B., Butler, A.M., Shalloo, L. (2011). A survey of the factors affecting future intentions of Irish dairy farmers. Journal of Agricultural Science, 149, 647-654.

Office of Child Nutrition, WV Department of Education. School Nutrition Programs Overview. Nov.27, 2013: http://wvde.state.wv.us/child-nutrition/school-nutrition-programs/.

Ostrom, M. (2006). Everyday Meanings of "Local Food": Views from Home and Field. Community Development, 37(1), 65-78.

Pennings, J.M.E., Irwin, S.H., Good, D.L., (2002). Surveying farmers: a case study, 24 (1), 266277.

Peters, C., Hansen, E., Clingerman, J., Hereford, A., and Askins, N. (2012). WV Food System: Opportunities and Constraints in Local Supply Chains. Report prepared for the WV Food and Farm Coalition by Downstream Strategies, September 2012.

R Data Analysis Examples: Probit Regression. UCLA Statistical Consulting Group. http://www.ats.ucla.edu/stat/r/dae/probit.htm (Accessed October, 2013). 
Robinson, J.P., Shaver, P.R., and Wrightsman, L.S. (1991). Criteria for scale selection and evaluation. In J.P. Robinson, P.R. Shaver, and L.S. Wrightsman (eds). Measures of Personality and Social Psychological Attitudes. Academic Press, New York, NY, p. 116.

Sage, C. (2003). Social Embeddedness and Relations of Regard: Alternative 'Good Food' Networks in South-West Ireland, Journal of Rural Studies, 19, 47-60.

Schupp, J.L., and Sharp, J.S. (2012). Exploring the social bases of home gardening. Agricultural and Human Values, 29, 93-105.

Selfa, T., and Qazi, J. (2005). Place, Taste, or Face-to-Face?: Understanding Producer-Consumer Networks in "Local" Food Systems in Washington State. Agriculture and Human Values, $22,451-464$.

Smith, A. and MacKinnon, J. B. (2007). The 100-Mile Diet: A Year of Local Eating. Random House Canada: Toronto, Ontario.

Thompson, E., Jr., A.M. Harper, and S. Kraus. 2008. Think Globally—Eat Locally: San Francisco Foodshed Assessment, American Farmland Trust. (In Martinez, et al. 2010)

Traikova,D., Mollers, J., Buchenrieder, G. (2012). How Farmers Become Entrepreneurs Prenatal Diagnostic of Rural Firms in Bulgaria. Selected Poster prepared for presentation at the International Association of Agricultural Economist (IAAE) Triennial Conference, Fox do Iguacu, Brazil, 18-24 August, 2012.

US Department of Agriculture (USDA) National Statistics Service (NASS) US Census of Agriculture: 2007. WV State data. 
US Food and Drug Administration (FDA). Background on the Food Safety Modernization Act (FSMA). March 18, 2013: http://www.fda.gov/Food/GuidanceRegulation/FSMA/ucm239907.htm

Van der Pligt,J., de Vries,N., 1995. Opinions and attitudes: measurement, models and theory (in Dutch), cited in Bergevoet, et al., 2004.

Walter, G. (1997). Images of Success: How Illinois Farmers Define the Successful Farmer. Rural Sociology, 62(1), 48-68. 


\section{Survey of Home Gardener and Farm Business Goals and Challenges}

This study will help food producers and farmers like you meet your goals and overcome challenges by helping to improve projects that seek to address your needs. By filling out this survey, you help us gather important information that will help future projects to do the best job of addressing your goals and challenges.

For your responses to be useful, we need you to answer all of the questions. If you have comments, or would like to expand on your answers, please use the margins or the space provided at the end.

Please return this completed survey along with the green paper with your gift card choice in the business reply envelope (no postage needed) that we've included.

Thank you for your help!

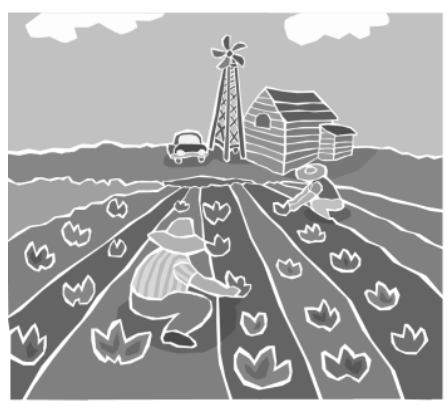

Agricultural and Resource Economics

Davis College of Agriculture, Natural Resources and Design

PO Box 6108 West Virginia University

Morgantown, WV 26505-6108 


\section{SECTION 1: FOOD PRODUCTION GOALS AND CHALLENGES}

*All producers please answer this section.

1. Did you raise any food products, such as vegetables, fruits, grains, meat or dairy animals, or other food product in 2012?

Yes, I did raise food products in 2012 (*CONTINUE TO QUESTION 2)

No, I did not raise any food products in 2012. (*If you did not raise food products in

2012 it is not necessary for you to fill out

this questionnaire. However, please

return it so we can take you off the

mailing list.

2. What was the primary reason that you became a farm or garden operator? (Please check only one reason.)

take over operation of the farm from a family member or another person develop a business to generate additional income investment in real estate live in a rural area retirement/residence activity growing crops and/or livestock that provide outdoor activity Other (please specify):

3. Which of the following resources do you have access to? (Please check all that apply.)

Water for irrigation

High tunnel or hoop house

Greenhouse

Family laborers

Hired laborers

volunteer laborers

Loans/credit
Land you own

Land you rent from someone

Equipment you own (tractors, processing equipment, etc.)

Equipment you rent from someone Other (please specify): 
4. Please indicate whether you agree or disagree with the following by placing an $X$ in the appropriate box.

\begin{tabular}{|c|c|c|c|c|c|}
\hline & $\begin{array}{l}\text { Strongly } \\
\text { Agree }\end{array}$ & Agree & $\begin{array}{l}\text { Neither } \\
\text { Agree or } \\
\text { Disagree }\end{array}$ & Disagree & $\begin{array}{l}\text { Strongly } \\
\text { Disagree }\end{array}$ \\
\hline \multicolumn{6}{|l|}{$\begin{array}{l}\text { I plan to pass my farm/garden on to a } \\
\text { known successor. }\end{array}$} \\
\hline \multicolumn{6}{|l|}{ Farming is a viable business venture. } \\
\hline \multicolumn{6}{|l|}{$\begin{array}{l}\text { Off-farm income is important for the } \\
\text { continuity of my farm or garden. }\end{array}$} \\
\hline \multicolumn{6}{|l|}{$\begin{array}{l}\text { In the future my household would like } \\
\text { to farm full-time with no off-farm } \\
\text { income. }\end{array}$} \\
\hline \multicolumn{6}{|l|}{$\begin{array}{l}\text { My household prefers to have off- } \\
\text { farm income as well to reduce risk. }\end{array}$} \\
\hline \multicolumn{6}{|l|}{$\begin{array}{l}\text { My household prefers to have off- } \\
\text { farm work to be able to get health } \\
\text { insurance. }\end{array}$} \\
\hline \multicolumn{6}{|l|}{$\begin{array}{l}\text { I would encourage youth to pursue } \\
\text { farming. }\end{array}$} \\
\hline \multicolumn{6}{|l|}{$\begin{array}{l}\text { I have written my goals for my } \\
\text { farm/garden down on paper. }\end{array}$} \\
\hline \multicolumn{6}{|l|}{$\begin{array}{l}\text { Local food strengthens our } \\
\text { community. }\end{array}$} \\
\hline \multicolumn{6}{|l|}{ Local food strengthens our economy. } \\
\hline \multicolumn{6}{|l|}{ Farm work is a chore without joy. } \\
\hline \multicolumn{6}{|l|}{$\begin{array}{l}\text { People value my role as a } \\
\text { farmer/gardener. }\end{array}$} \\
\hline \multicolumn{6}{|l|}{$\begin{array}{l}\text { It's important to me to raise my } \\
\text { family with farming/gardening. }\end{array}$} \\
\hline $\begin{array}{l}\text { It's important to eat food produced } \\
\text { without chemicals. }\end{array}$ & & & & & \\
\hline
\end{tabular}

\section{Please describe your goals for your garden or farm.}


6. How many of the following did you raise in $\mathbf{2 0 1 2}$ and how many do you plan to raise in 2014, two years from now?

\begin{tabular}{|l|l|l|}
\hline & Number raised in 2012 & Number plan to raise in 2014 \\
\hline Beef calves & & \\
\hline Fattened beef & & \\
\hline Broilers & & \\
\hline Laying hens & & \\
\hline Piglets & & \\
\hline Pork & & \\
\hline Lambs & & \\
\hline Meat goats & & \\
\hline Dairy cows & & \\
\hline Dairy goats & & \\
\hline Fruit trees (specify type): & & \\
\hline $\begin{array}{l}\text { Berry plants (specify type): } \\
\text { Vegetables } \\
\text { (Specify acres/square feet or } \\
\text { wescribe size of plot in own } \\
\text { words) }\end{array}$ & & \\
\hline $\begin{array}{l}\text { Other: } \\
\text { nats }\end{array}$ & & \\
\hline
\end{tabular}

7. Which of the following best describes your food production plans for the next 2 years? (Please check only one).

I plan to produce more overall.

I plan to produce the same amount overall.

I plan to produce less overall.

I plan to stop farming or gardening entirely.

I am not sure. 
8. Please estimate what percentage of your diet is made up of food products that you raise. Percent

9. Do you use any of the following terms to describe the food products that you raise? (Please check all that apply.)

Grass-fed animals

Free-range animals

Organic

Certified organic

Naturally grown
Certified naturally grown

No spray/pesticides

Certified humane

Other (please specify):

10. Which of the following marketing outlets do you plan to sell through sometime in the next two years? (Please check all that apply).

None

Farmers Market(s)

Roadside Stand or on-farm store

Processor or Finisher

Restaurants

Vegetable auctions

Community Supported Agriculture

(CSA)
_ Grocery Stores

Live animal stockyard or buyer Schools Hospitals

Not sure

Other (specify):

11. How many miles (one-way) is the closest place where you could sell your food products? (ie. Farmers market, food hub, or buyer, etc.)?

Number of miles

12. Did you sell any of the food products you produced in 2012 ?

YES (*SKIP TO SECTION 2)

NO (*CONTINUE TO QUESTION 13) 
13. Since you indicated in question 12 that you DID NOT SELL any of the food products you produced in 2012, please tell us whether you agree or disagree with the following reasons for choosing not to sell food products by placing an $\mathrm{X}$ in the appropriate column.

\begin{tabular}{|l|l|l|l|l|l|}
\hline & $\begin{array}{c}\text { Strongly } \\
\text { Agree }\end{array}$ & Agree & $\begin{array}{c}\text { Neither } \\
\text { Agree or } \\
\text { Disagree }\end{array}$ & Disagree & $\begin{array}{c}\text { Strongly } \\
\text { Disagree }\end{array}$ \\
\hline $\begin{array}{l}\text { I'm not interested in selling the } \\
\text { food I raise - it's just a hobby. }\end{array}$ & & & & & \\
\hline $\begin{array}{l}\text { It is too far for me to travel to sell } \\
\text { at a profitable marketing outlet. }\end{array}$ & & & & & \\
\hline $\begin{array}{l}\text { I don't have time to sell the foods } \\
\text { that I grow/raise. }\end{array}$ & & & & & \\
\hline $\begin{array}{l}\text { I have difficulty hiring the kind of } \\
\text { labor that I need. }\end{array}$ & & & & & \\
\hline $\begin{array}{l}\text { It would not be profitable to sell } \\
\text { the foods I produce. }\end{array}$ & & & & & \\
\hline $\begin{array}{l}\text { I don't think there is enough } \\
\text { demand in local markets. }\end{array}$ & & & & & \\
\hline $\begin{array}{l}\text { Pest/disease problems limit my } \\
\text { ability to sell my products. }\end{array}$ & & & & & \\
\hline $\begin{array}{l}\text { Complicated regulations make it } \\
\text { difficult to sell the food I produce. }\end{array}$ & & & & & \\
\hline $\begin{array}{l}\text { I am afraid of the consequences if } \\
\text { the food I produce makes } \\
\text { someone sick. }\end{array}$ & & & & & \\
\hline $\begin{array}{l}\text { I'd rather give away my extra } \\
\text { produce than sell it. }\end{array}$ & & & & & \\
\hline $\begin{array}{l}\text { I used to sell but am now retired. } \\
\text { nome }\end{array}$ & & & & & \\
\hline
\end{tabular}

14. Is there any other reason why you decided not to sell the food you produced in 2012 ?

*If you answered questions 13 and 14, now *SKIP TO SECTION 3. 


\section{SECTION 2. FOOD MARKETING GOALS AND CHALLENGES}

*If you indicated in question 12 that you SOLD food products in 2012, please answer this section. If you DID NOT SELL food products in 2012, please skip to Section 3.

15. Which reason best describes why you sell the food you raise? (Please check only one.) I produce more than we can eat, so I might as well sell the extra. I sell my food products to earn income. I enjoy the social connections I get when selling the food products I produce. Other (please specify):

16. What percent of your farm income in 2012 was from sales through the following marketing outlets? (Note: They should add up to 100.)

\begin{tabular}{|c|c|c|c|}
\hline Marketing Outlet & $\%$ & Marketing Outlet & $\%$ \\
\hline Farmers Market(s) & — $\%$ & Roadside Stand or On-farm Store & $\%$ \\
\hline $\begin{array}{l}\text { Community Supported Agriculture } \\
\text { (CSA) }\end{array}$ & — $\%$ & Processor or Finisher & $\%$ \\
\hline Restaurants & $\%$ & Vegetable auctions & $\%$ \\
\hline Grocery Stores & $\ldots$ & Live animal stockyard or buyer & $\%$ \\
\hline $\begin{array}{l}\text { Schools } \\
\text { Hospitals }\end{array}$ & $\begin{array}{r}\% \\
\%\end{array}$ & Other (please specify): & $\overline{\%}$ \\
\hline
\end{tabular}

17. Which broad category best represents the gross sales from your farm in 2012 ?

Less than $\$ 1,000$

$\$ 1,000-\$ 2,499$

$\$ 2,500-\$ 4,999$

$\$ 5,000-\$ 9,999$
$\$ 10,000-\$ 24,999$

$\$ 25,000-\$ 39,999$

$\$ 40,000-\$ 49,999$

$\$ 50,000-\$ 99,999$

$\$ 100,000-249,999$
$-\quad \$ 250,000-499,999$
$-\quad \$ 500,000-999,999$
$-\quad \$ 1,000,000$ or more

18. Which broad category best represents your goal for your farm's gross sales in 2014?

Less than $\$ 1,000$

$\$ 1,000-\$ 2,499$

$\$ 2,500-\$ 4,999$

$\$ 5,000-\$ 9,999$
$\$ 10,000-\$ 24,999$

$\$ 25,000-\$ 39,999$

$\$ 40,000-\$ 49,999$

$\$ 50,000-\$ 99,999$
\$100,000-249,999

\$250,000-499,999

$\$ 500,000-999,999$

$\$ 1,000,000$ or more 
19. Please indicate how much the following factors do or do not limit your ability to expand your farm by placing an $\mathrm{X}$ in the appropriate box.

\begin{tabular}{|l|l|l|l|l|}
\hline & $\begin{array}{l}\text { Do not } \\
\text { limit me }\end{array}$ & $\begin{array}{l}\text { Limit me } \\
\text { somewhat }\end{array}$ & $\begin{array}{l}\text { Limit me a } \\
\text { lot }\end{array}$ & Undecided \\
\hline Low prices for products sold & & & & \\
\hline Pest/disease problems & & & & \\
\hline Not enough water & & & & \\
\hline Not enough land & & & & \\
\hline $\begin{array}{l}\text { Limited access to larger-scale } \\
\text { equipment }\end{array}$ & & & & \\
\hline $\begin{array}{l}\text { Difficulty hiring the type of labor I } \\
\text { need }\end{array}$ & & & & \\
\hline Complicated regulations & & & & \\
\hline $\begin{array}{l}\text { Lack of time to market/distribute } \\
\text { my products }\end{array}$ & & & & \\
\hline $\begin{array}{l}\text { Lack of production-related } \\
\text { knowledge }\end{array}$ & & & & \\
\hline Long travel distance to market & & & & \\
\hline $\begin{array}{l}\text { Lack of demand in markets for my } \\
\text { products }\end{array}$ & & & & \\
\hline Lack of access to local processing & & & & \\
\hline $\begin{array}{l}\text { Lack of marketing-related } \\
\text { knowledge }\end{array}$ & & & & \\
\hline $\begin{array}{l}\text { Lack of money to invest in } \\
\text { expansion }\end{array}$ & & & & \\
\hline High input costs & & & & \\
\hline High processing costs & & & \\
\hline
\end{tabular}

20. Please comment on the greatest limitations you face to producing or marketing the food you produce. 


\section{SECTION 3: FARM OR GARDEN BACKGROUND}

*All producers please answer this section.

Your answers help us learn about WV gardeners/farmers and help us understand results.

21. Where is your garden or farm located?

County

State

22. Do you own and/or rent the land where you farm/garden?

_ Own part, rent a part $\rightarrow($ CONTINUE to question 23)

Own all $\rightarrow(*$ CONTINUE to question 23 $)$

Rent all $\rightarrow(*$ SKIP to question 24)

23. Since you indicated in question 22 that you own land where you garden or farm, how many generations has it been in your family? (*If you are the first generation please put 1). Number of generations

24. How many acres of usable agricultural land do you have access to? Number of acres

25. How long have you been gardening or farming at your current location? Number of years

26. How many years of experience do you have farming or gardening? Number of years

27. How many other people work on your farm or garden?

Number of people

28. What is your age?

Number of years

29. What is your gender?

Male

Female

30. Are you employed off or away from the farm?

_Y Yes, part-time Yes, full-time No 
31. Which broad category BEST describes your total household income level in 2012 ?

less than $\$ 10,000$

$\$ 10,000-\$ 14,999$

$\$ 15,000-\$ 19,999$

$\$ 20,000-\$ 24,999$

$\$ 25,000-\$ 29,999$

$\$ 30,000-\$ 34,999$

\begin{tabular}{|c|}
\hline$\$ 40,000-\$ 44,99$ \\
\hline$\$ 45,000-\$ 49,99$ \\
\hline$\$ 50$ \\
\hline$\$ 60,000-\$ 6$ \\
\hline \\
\hline
\end{tabular}
$\$ 80,000-\$ 89,000$ $\$ 90,000-\$ 99,000$ $\$ 100,000-\$ 124,999$ $\$ 125,00-\$ 149,999$ $\$ 150,000-\$ 199,999$ $\$ 200,000$ or more

32. What is the highest level of education that you have completed?

Less than $9^{\text {th }}$ grade $9^{\text {th }}$ to $12^{\text {th }}$ grade, no diploma High School graduate (includes GED)
Some College, no degree Associate's degree Bachelor's degree Graduate or Professional degree

33. Which category(s) best describes your main ancestry?

American
Dutch
English
French

American

French

__ German
__ Irish
__ Scottish
__ Scotch-Irish

Italian

Polish Other:

34. Which sentence best describes your residence in WV? Please check only one. I was raised in WV, and at least one of my parents was raised in WV. I was raised in WV, but neither of my parents were raised in WV. I was not raised in WV, and I came here to farm. I was not raised in WV, and I came here for other reasons. I was not raised in $\mathrm{WV}$, and I do not live in $\mathrm{WV}$.

35. Which phrase best describes your ancestors' place in WV history.

My ancestors did not live in WV. I don't know why my ancestors first came to WV. My ancestors came to WV to work in the mining industry. My ancestors came to WV to work in the timber industry. My ancestors came to WV to farm. My ancestors came to WV for another reason (please specify): 
35. Please tell us what kinds of initiatives or programs would help you in your farming or gardening operation. (Examples could include programs, workshops, trainings, handouts, connections to resources or markets, other, etc.). Please specify the topic area or need that you believe needs to be addressed.

\section{Thank you for your time and help!}

Don't forget to fill out the green slip with your gift card preference and mail it back to us with this survey questionnaire! 


\title{
Appendix 2. Letter of request for participation in survey
}

February 26, 2013

Producer

Address

Dear [name of producer],

What is your vision for your farm or garden in the future? What challenges do you face? The answers to these questions are important to the future of your garden or farm and for meeting the food needs of West Virginians. I write to request your help with a research study that seeks to answer and address these questions to help you meet your goals.

You received this letter because you have been involved with local food production efforts in WV. Specifically, I ask you to provide your insight by filling out a survey questionnaire. Survey results will be used to improve production and marketing programs in WV to best help gardeners and farmers like you to overcome challenges and reach your goals.

As a token of appreciation of your help, I will send you a free \$10 gift card to Southern States store or Johnny's Seeds online catalog when I receive your completed questionnaire.

The survey questionnaire is available by regular mail or internet.

gIf you choose the internet option, there is no need to return this letter, and you may go online now to take the survey at this link: https://www.surveymonkey.com/s/NESAREproducersurvey. Your code is: 97798.

If you prefer to participate by mail, please return this letter in the envelope provided (no postage required). We will send you a paper copy of the survey.

Your participation is completely voluntary and all information will be kept confidential. Survey results will be reported as aggregate and anonymous information only. When you return your completed questionnaire, your name will be deleted from the mailing list and will not be connected to your answers. West Virginia University's Institutional Review Board (IRB) acknowledgement of this project is on file. This study is funded by the U.S. Department of Agriculture's Northeast Sustainable Agriculture Research and Education Program (NESARE). If you have any questions about this study, please contact me at Ruth.Oldham@mail.wvu.edu or (304) 692-1044, or the Principal Investigator, Cheryl Brown, Associate Professor, at Cheryl.Brown@mail.wvu.edu or (304) 293-5461.

Thank you very much for considering my request to participate in this important study!

\author{
Sincerely, \\ Mary Oldham \\ Graduate Student, Agricultural Economics
}




\section{Appendix 3. Descriptive Statistics for all Survey Questions}

The following tables illustrate the descriptive statistics for all survey questions. Survey participants were guided through the survey only to answer certain questions. For example, producers who sold food products in 2012 answered a section of questions related to their marketing and sales, while the producers who did not sell their food products in 2012, were guided to a unique section that explored their reasons for not selling. The questions, pertinent description, summary statistics, and a list of open ended responses are presented below for all survey questions.

Open-ended responses are displayed in producers own words with no attempt to categorize or correct them. However, any information that would reveal the identity of the respondent is not included in order to protect the anonymity and privacy of participants.

\section{Question 1: Did you raise any food products such as vegetables, fruits, grains, meat or dairy animals, or other food product in} 2012?

This question was included for screening purposes to ensure that respondents were producers of food products.

Of the 1705 surveys sent out, 1511 were delivered. A total of 194 surveys were undeliverable; 116 came back marked "return to sender" and 78 contained notes indicating that the target participant was deceased or no longer produced food. A total of 574 surveys were received that answered "YES" to this question to indicate that the participant produced food in 2012, and were included in the sample. 
Question 2. "What was the primary reason that you became a farm or garden operator? (Please check only one reason.)" All producers were asked to answer this question. In the following table, SUM refers to the total number of observations coded as "1 " for the dummy variables. $N=514$

\begin{tabular}{|c|c|c|c|c|c|c|}
\hline Description & DATA CODE & MEAN & $\begin{array}{l}\text { STD. } \\
\text { DEV }\end{array}$ & MIN & MAX & SUM \\
\hline $\begin{array}{l}\text { Take over operation of the farm from a family member or } \\
\text { another person }\end{array}$ & RFARM & 0.18 & 0.39 & 0 & 1 & 93 \\
\hline Develop business to generate additional income & RINC & 0.24 & 0.42 & 0 & 1 & 121 \\
\hline Investment in Real Estate & RINV & 0.00 & 0.04 & 0 & 1 & 1 \\
\hline Live in a rural area & RRURAL & 0.13 & 0.33 & 0 & 1 & 66 \\
\hline Retirement/residence activity & RRETIRE & 0.10 & 0.30 & 0 & 1 & 50 \\
\hline Growing crops and/or livestock that provide outdoor activity & ROUTDOOR & 0.13 & 0.34 & 0 & 1 & 69 \\
\hline Other & ROTHER & 0.22 & 0.42 & 0 & 1 & 114 \\
\hline
\end{tabular}

Responses listed under “Other" to question 2, "Reason for entering farming”. $N=130$

- a tradition from the day i was born

- a way of life: nutrition, health, environmental, spiritual

- access to fresh organic produce

- add vegetable/marketable crops to our farm

- all of above

- always had a passion for farming, finally getting to live the dream

- always vision to live on farm and raise sheep to utilize land that was too steep/rocky to produce any other crop

- been generation to and from - enjoy it - raise family by

- better nutrition and health status

- born and raised on family farm and bought my own farm in 1972. passion for farming

- business/college education

- control of how my food is grown
- decision to make a living by farming with no other income

- enjoy \& food is better

- enjoy doing it

- enjoy farming/gardening

- enjoy it and opened up a greenhouse

- enjoy raising a garden and visiting with the public to sell.

- family and community volunteer support, gift donate sharing

- family farm

- family usage and farmers markets

- family use

- family use

- farmers market and home use

- feed our family

- feed the world

- food 
- food

- food for family

- food for family (raised by us)

- for my health

- for my restaurant

- for our food

- fresh meat and vegetables for home use

- garden with grandchild

- good and safe food and make money

- $\operatorname{good}$ food to eat

- grow and preserve a portion of my own food supply

- grow garden for home canning

- grow healthy foods for myself, my family, my neighbors

- grow my own food

- grow my own food for purity and share with community

- grow my own vegetables for home use

- growing crops for food stock for our family

- growing food free of pesticides/chemicals that is not genetically modified

- growing food to feed my family and others

- have always raised our food

- have food for own use

- health benefits to family and community of local, fresh foods

- help off-set food cost

- help with groceries

- higher quality food production

- hobby

- home use

- home use and business

- home use vegetables hone and planted blueberries

- home-grown, fresh vegetables and fruits are much tastier than store-bought - harvested at peak of ripeness

- I always have no real reason

- I grew up on a farm and enjoy farming and raising my own wholesome food.
- I just wanted to be a farmer

- I like raising my own vegetables and produce always have

- I wanted an occupation that would make the world a better place

- inherited 5th generation

- interested at a young age with agriculture

- it's necessary for your life

- life-time farmer

- like fresh veggies

- like to preserve fresh food for winter instead of buying

- living off the land - canning

- love of horticulture

- $\quad$ made a living by feeding people good food

- made note that are equal

- organic food

- organic food

- $\quad$ parents and grandparents raised livestock and seed fruits and vegetables

- passion/lifelong experience

- personal food/income

- personal health and fulfillment

- personal interest and enjoyment

- primary income/job/lifestyle. it's not extra money - its how we live/survive and that's why when people already have steady income it makes it harder for us to survive

- $\quad$ provide for self

- provide fresh garden produce for our family

- $\quad$ provide fresh vegetables for family

- provide nutrient dense food for family and farm animals:wild and domestic

- $\quad$ provide organic (mostly) fruits and vegetables and beef for the family

- provide own food source

- quadruple bypass so I needed a job I could move around

- $\quad$ raise fresh food for family, friends, others 
- $\quad$ raised on farm trying to do the same with my family

- $\quad$ save money by producing some of our own food.

- self-reliance

- show hobby

- $\quad$ social connection, part of an intentional community

- $\quad$ spend time outdoors with family

- the farm is our biggest asset and it was generating no income, we wanted to live in a rural area and make use of that asset. and live next door to family again.

- to can own vegetables

- to cut back on cost of food

- to earn a living

- to establish a better diet and better nutrition for myself, family, and WV and to feed my family/neighbors; contribute to local food pantry

- to feed myself and children organically

- to grow and raise our food

- to grow healthy food

- to grow my own organic food.

- to grow organic food for family

- to grow our family and others healthy organic non-gmo food!

- to grow our own food
- to grow the kinds of food that i like to eat and could not find at the grocery store

- to grow wholesome food

- to have access to a greater variety of organically grown vegetables and fruits

- to have access to superior vegetables at low cost.

- to have food for my family

- to have quality food for my family

- to help maintain land to feed ourselves and others

- to operate a for profit business for income

- to prevent unwanted growth

- $\quad$ to provide food for my family

- to provide fresh, clean food for my community and family

- to provide myself with fresh organic produce

- to provide produce, milk, eggs for family and sell the excess.

- to raise the food I eat so I know what I am eating

- to self-sustain food for the years to come

- to supplement my family (food)

- tradition, love for growing fruits and vegetables

- use land instead of letting it sit

- vegetarian

- we grow our gardens for the good vegetables

- $\quad$ work towards sustainable lifestyle (\& outdoor activities) 
Question 3. "Which of the following resources do you have access to? (Please check all that apply.)"

All participants were asked to answer this question. In the following table, SUM refers to the total number of observations coded as "1" for the dummy variables. $N=566$

\begin{tabular}{|c|c|c|c|c|c|c|}
\hline Description & DATA CODE & MEAN & $\begin{array}{l}\text { STD. } \\
\text { DEV }\end{array}$ & MIN & MAX & SUM \\
\hline Access to water for irrigation & IRRIGATE & 0.49 & 0.50 & 0 & 1 & 278 \\
\hline High tunnel or hoophouse & HTUNNEL & 0.17 & 0.37 & 0 & 1 & 95 \\
\hline Greenhouse & GHOUSE & 0.18 & 0.39 & 0 & 1 & 103 \\
\hline Family laborers & FAMLABOR & 0.47 & 0.50 & 0 & 1 & 267 \\
\hline Hired laborers & HLABOR & 0.15 & 0.36 & 0 & 1 & 86 \\
\hline \begin{tabular}{|l|} 
Volunteer laborers \\
\end{tabular} & VLABOR & 0.12 & 0.32 & 0 & 1 & 66 \\
\hline Loans/Credit & LOANCRED & 0.18 & 0.39 & 0 & 1 & 103 \\
\hline Land you own & LANDOWN & 0.93 & 0.26 & 0 & 1 & 526 \\
\hline Land you rent from someone & LANDRENT & 0.18 & 0.39 & 0 & 1 & 103 \\
\hline Equipment that you own & EQUIPOWN & 0.78 & 0.41 & 0 & 1 & 442 \\
\hline Equipment that you rent from someone & EQUIPRENT & 0.03 & 0.18 & 0 & 1 & 18 \\
\hline Other & RESOTHER & 0.05 & 0.22 & 0 & 1 & 28 \\
\hline
\end{tabular}

\section{Responses given under “Other”, Question 3, $N=22$}

- barter with neighboring farmers for equipment services

- caretaking land, equipment \& property - no rent or ownership

- cold frames, light table

- family farm

- family owned land

- garden plot

- garden tiller

- good barns for livestock and hay storage; root cellar

- grants

- had a greenhouse until collapsed

- infrastructure in place on the farm
- knowledge and experience

- land allowed to use by neighbors.

- land and equipment are owned by extended family but used free of charge

- low tunnel

- machine hire

- rototiller, weeder and general garden tools

- small building

- small equipment; raised beds and square feet gardening only

- store

- tillers, trimmers, pruners, chainsaws, and hand tools.

- will have greenhouse in the near future 
Question 4. This set of questions was asked to explore producers' attitudes about producing food and farming. All participants were asked to answer these questions. Producers were asked to indicate whether they agreed or disagreed with the statements. In this table, values in the columns labeled " 1 " to " 5 " represent percentage of respondents, $N$, whose answers corresponded to the following options along a Likert scale. $1=$ Strongly disagree, 2=Disagree, 3=Neither agree nor disagree, 4=Agree, and 5=Strongly Agree. NA refers to the percentage of respondents who skipped or did not indicate an answer for the given statement.

\begin{tabular}{|c|c|c|c|c|c|c|c|c|c|c|c|c|c|}
\hline Description & DATA CODE & $\mathbf{N}$ & MEAN & $\begin{array}{l}\text { STD. } \\
\text { DEV }\end{array}$ & MIN & MAX & SUM & 1 & 2 & 3 & 4 & 5 & NA \\
\hline I plan to pass my farm/garden on to a known successor. & SUCC & 546.00 & 3.83 & 1.13 & 1 & 5 & 2091 & $4 \%$ & $8 \%$ & $25 \%$ & $26 \%$ & $37 \%$ & $5 \%$ \\
\hline Farming is a viable business venture & VIABLE & 539.00 & 3.77 & 0.96 & 1 & 5 & 2032 & $2 \%$ & $9 \%$ & $23 \%$ & $44 \%$ & $23 \%$ & $6 \%$ \\
\hline Off-farm income is important for the continuity of my farm. & OFFINC & 523.00 & 3.99 & 1.02 & 1 & 5 & 2089 & $3 \%$ & $8 \%$ & $13 \%$ & $41 \%$ & $36 \%$ & $10 \%$ \\
\hline $\begin{array}{l}\text { In the future my household would like to farm full-time with no } \\
\text { off-farm income. }\end{array}$ & FULLTIME & 552.00 & 3.14 & 1.23 & 1 & 5 & 1733 & $9 \%$ & $25 \%$ & $28 \%$ & $21 \%$ & $18 \%$ & $4 \%$ \\
\hline $\begin{array}{l}\text { My household prefers to have off-farm income as well to reduce } \\
\text { risk. }\end{array}$ & OFFRISK & 526.00 & 3.80 & 0.98 & 1 & 5 & 1998 & $2 \%$ & $8 \%$ & $23 \%$ & $42 \%$ & $25 \%$ & $9 \%$ \\
\hline $\begin{array}{l}\text { My household prefers to have off-farm work to be able to get } \\
\text { health insurance. }\end{array}$ & OFFINS & 553.00 & 3.86 & 1.15 & 1 & 5 & 2133 & $4 \%$ & $11 \%$ & $19 \%$ & $29 \%$ & $38 \%$ & $4 \%$ \\
\hline I would encourage youth to pursue farming. & YOUTH & 542.00 & 4.16 & 0.85 & 1 & 5 & 2254 & $0 \%$ & $4 \%$ & $16 \%$ & $40 \%$ & $40 \%$ & $6 \%$ \\
\hline I have written my goals for my farm/garden down on paper. & WRITGOAL & 546.00 & 2.98 & 1.11 & 1 & 5 & 1627 & $7 \%$ & $29 \%$ & $34 \%$ & $18 \%$ & $12 \%$ & $5 \%$ \\
\hline Local food strengthens our community. & LFCOM & 541.00 & 4.51 & 0.64 & 1 & 5 & 2442 & $0 \%$ & $1 \%$ & $6 \%$ & $35 \%$ & $59 \%$ & $6 \%$ \\
\hline Local food strengthens our economy. & LFECON & 553.00 & 4.50 & 0.63 & 1 & 5 & 2490 & $0 \%$ & $1 \%$ & $5 \%$ & $38 \%$ & $57 \%$ & $4 \%$ \\
\hline Farm work is a chore without joy. & FWCHORE & 494.00 & 1.74 & 0.89 & 1 & 5 & 858 & $47 \%$ & $39 \%$ & $9 \%$ & $3 \%$ & $2 \%$ & $16 \%$ \\
\hline People value my role as a farmer/gardener. & ROLEVALUE & 556.00 & 3.82 & 0.83 & 1 & 5 & 2125 & $1 \%$ & $5 \%$ & $23 \%$ & $53 \%$ & $19 \%$ & $3 \%$ \\
\hline It's important to me to raise my family with farming/gardening. & RAISEFAM & 546.00 & 4.35 & 0.70 & 1 & 5 & 2373 & $0 \%$ & $1 \%$ & $10 \%$ & $43 \%$ & $46 \%$ & $5 \%$ \\
\hline It's important to eat food produced without chemicals. & NOCHEM & 555.00 & 4.25 & 0.94 & 1 & 5 & 2360 & $2 \%$ & $3 \%$ & $12 \%$ & $32 \%$ & $50 \%$ & $3 \%$ \\
\hline
\end{tabular}

\section{Question 5: "Please describe your goals for your garden or farm."}

All producers were asked to respond to this open-ended question. All responses are presented as follows in the words of the producers. $N=476$

- $1 . f a r m$ as a viable, business that helps sustain a family with exception to income (spiritual, physical); 2) provide our family with a common goal, work together

- 1.Construct high tunnel for year round gardening 2. Balance PH/nutrients in existing hay field and pastures 3. Fence pasture for grass-fed beef operation

- 1.it's important to eat food without chemicals and the taste is delicious and nutritious. 2. and most veggies and fruits will produce seeds. 
- 1. Provide fresh on farm food for my family 2. Provide safe vegetables and fruits for local farmers market. 3. Develop new markets for my produce 4. Farm responsibly and to be mindful of soil, and livestock welfare. 5. Enjoy benefits of healthier food and budgetary the benefits of raising my own food.

- 1.To keep our family's land in production agriculture while sustainably farming and improving the soils, 2 . To have at least one of the adults in our household be able to farm while caring for our children, with no use of day care - we choose to raise our own children. 3. To raise wholesome food for our family and to sell to others in our community. 4. To be a pioneer in the types of produce we grow, the way we grow it, the types of sales outlets, and types of value added products so we can share that knowledge with others.

- 17 acres produce

- Achieve financial viability and have a perennial garden

- Add fencing, divide pastures, move and enlarge garden area, add fruit trees.

- after my retirement I plan to resume growing enough produce to sell once again. Due to long outside (off-the farm) work hours I grow only for family and friends.

- am trying to get farm producing enough to be self-sufficient

- An integrated system of poultry, garden products with byproducts producing compost for use on the land.

- animals and veg to sell to restaurants

- as I get older I am doing less gardening because of health issues

- as long as my health allows, I plan on gardening/farming and will continue to grow these areas of operation year to year.

- As much as possible, to grow the foods that I consume.

- at age 78 I have over the years depended on farm produce

- Be able to work in my garden, enjoy seeing crops grow, love using garden foods for canning, preserving and food for my family and neighbors.

- be self-supporting in 5 yrs. Improve land and water. Pass on the farm to our grandson.

- beef cattle operation, sell some small vegetables

- Being able to have locally raised produce at the farmers market every week. Continue to increase my beef herd to make a viable source of income.

- Break even and recoup capital investments for future positive cash flow.

- build more hoophouse to raise food and plants year round

- clear brush/improve fertility on 3 acres of pasture to support milk cow and beef calf, plus more poultry. These animals are the source of manure for the vegetable garden, which I would like to expand to 1.5 acres. Also plant a few more fruit trees and have bees again.

- Continue growing herbs for pleasure.

- continue to do the same as in the past - get through difficult economical struggles

- Continue to evolve with the changing demands of consumers. Show that farming is a profession. Be profitable. Provide healthy food for the community.

- continue to grow as a farm to one day run 200 cow/calf pairs

- continue to make a profit-remain a family business. 
- continue to raise vegetables for home \& family to eat fresh in season \& canning for winter/non-seasonal months. also to continue to raise chickens for eggs \& meat.

- continue to strengthen/grow the business

- cut cost and joy life

- to build a family oriented business focused on livestock feed and fresh vegetables at affordable prices.

- desire to have fresh vegetables for personal consumption and sell (or give away) the excess.

- don't have any

- don't have goal

- double the size this year and produce even more cheaply

- Earn a better living, and have something for the family.

- eat quality organic food year round

- $\quad$ eat totally off-farm with very little store supplement

- Enjoy the fruits of our labor, Raise enough to share with others, sell enough to cover minor investments.

- exercise; become totally organic

- expand cattle operation

- $\quad$ expand land and products and new things

- extra good food

- family use - farmers market - to provide fresh veg. not for the income

- family use, plus sell enough at farmers market to help pay for seeds. Very expensive.

- farm to best self-sustaining.

- farm will stay in family with one owner - but other family members can use it for support and recreation.

- feed as many people as God will allow me to.

- feed family, curb inflation on family funds

- feed multiple families, generate a nice living income

- feed people the healthiest and tastiest food possible while making enough money to live in modest comfort

- feed the family.

- Financially sustainable operation that provides a healthy work opportunity and food for our community.

- food for family and to sell at a farmers market

- for it to operate without added income or pay for its way without outside money

- for my family's enjoyment and to make a little extra money

- Fresh produce for the family and friends

- garden - eliminate weed/insect problems; farm- continue to develop water/improve fence; access and overall nurturing of the land.

- garden: To grow enough vegetables to can for winter to reduce grocery bills and to provide chemical free food for my family and a few friends when there is a surplus 
- gardening means eating healthy food. Raising your own beef -you know what you eat.

- generate income

- getting the high tunnel up and running get attached to school programs extending our greenhouse possibly quitting outside job and doing the farm full time start selling eggs

- give more to people

- grow and raise $90 \%$ of our food supply all meat for family.

- Grow enough to feed family and friends.

- Grow our own produce and meat source. I would like to have 100 cattle for calving operation. And I would like to plant grapes and fruit trees.

- grow own food, enjoyment-exercise, extra income, social interactions

- Grow produce for personal use and sell excess to the local farmers' market which supports a local charity. Lease the farm to run cattle for filth control and hay removal.

- Grow quality produce for family consumption and sales to the public, that is free of chemicals and is not genetically modified using sustainable practices.

- $\quad$ have enough beef to support my family and eat the grass down.

- have family members involved in our farm located in WV

- have not written them down on paper

- have some fresh veggies

- having own food source

- help build local economy and resilient community with production of healthy and clean fruits, vegetables, and meats

- hobby

- home grown food

- I am gradually reducing the scope of my gardening and farming due to age and health.

- I am not retired and plan to raise beef cattle as long as I am physically able, and then pass the farm to my children

- I am retired

- I am retired and enjoy my garden and farm and like to give family part of my crops

- I am retired but as long as I am able I will always raise beef buy a hog from a good farmer and raise a garden.

- I am using our farm to teach our children the value of hard work. They do the work, then they will receive the money.

- I continue to accept the increase from God's gift to s and want to continue to share with others. I am retired for 20 plus years with means to support us.

- I garden and raise rabbits for family food. It is more of a hobby.

- I have 100 blueberries. I'm hoping they will produce soon so I can sell them and save some. I enjoy gardening and selling my eggs at garden market.

- I have a stewardship plan for my forestland which lists the growing of wood products and Christmas trees as primary goals. Secondary goals are recreation, wildlife, hunting, and green space. I have no written plan for my garden and fruit trees, but I grow for my own use 
and sell what I cannot use. I have a garden to produce food for my family with any excess going to my local farmers market. We also raise beef cattle and goats.

- I have always loved to garden and it has grown to include fruits and vegetables that are organic and I can earn a bit of income with the extras. We have branched out to include jams and jellies that are not commonly found for sale and we would like to expand that portion of our farm.

- I have two areas of interest. The first is my beef cattle. I study genetics to improve my small cattle herd. The second is food and flower gardening. I grow plants for seeds and supply neighbors and friends with garden plants. i love to supply my family with hormone and antibiotic free beef and organic vegetables.

- I just like to see people standing in line to buy fresh produce and come back the next week to buy more

- I like good food this is main reason I garden. I try to sell enough to pay my taxes and expenses of garden.

- I like to grow food that we eat. I believe that I can sell that food to neighbors \& friends that also value clean food.

- I like to raise food for family and friends

- I live on the farm I was born on. Our children will have it when we die.

- I love to plant fruit tree seed and see what I get. A good fruit tree or scrub and raise my own plants with no chemicals, just cow manure.

- I plan to become a full time farmer. Health insurance premium are a big obstacle

- I plan to continue my farming and gardening, as well as, pass this on to my younger generations.

- I plan to produce livestock and poultry for meat use. We use our own fruit and garden products

- I plan to raise a broad variety of very high quality vegetables for my family and for sale in my community.

- I raise a small garden for home use and what I don't need I sell at farmers markets. If I break even I had a good year.

- I raise shitake mushrooms harvest depends solely on weather and the good lord

- I use the garden to get exercise and fun and to help others

- I want a high tunnel for raspberries. I would like to grow more fall and winter crops.

- I want to produce all our food from the farm for our retirement years

- I want to continue to grow my operation to be one of the largest corn/soybean farms in the state of WV and expand to other states.

- I want to expand and continue for generations to come.

- I want to farm sustainable with minimal inputs from outside sources. I also want to provide people with nutritious foods, grown with love and I want to teach people how to eat/cook with these foods that I produce.

- I want to make our farm/garden as self-sustaining as possible. I hope to raise chickens for eggs and meat and plan to raise a few cows for meat.

- I want to produce organic food to eat for us and friends and family.

- I want to raise crops and animals as long as I'm able while living on the family farm

- I want to raise my garden to provide quality produce for my family and local farmers market. We pasture cows for the summer and fall to secure beef without any chemicals

- I will farm 3 more years with good luck. 
- I would like my farm to become a self-sustaining form of income and I would like to participate eventually in local food to table/farm to school and like organizations for a more self-sustaining community.

- I would like to add a high tunnel or greenhouse in the future

- I would like to be able to pass my farm to my children so it would not be a burden to them rather something to enjoy.

- I would like to be able to raise home grown produce for self and family but with a herd of 12 deer visiting daily, I find it impossible.

- I would like to be self sufficient but reality tells me I can't raise enough to meet the financial drain of buying retail and selling everything wholesale. This includes fuel, tractors, spray, chemicals, seed, lime, fertlizers etc. there is no guarantee when we have a bumper crop of being able to sell anything or very little.

- I would like to become sustainable. Having bees, dairy cow and goats, more chickens for egg production, Rabbits for meat and increase my vegetable and fruit production. To have a certified kitchen and become certified organic.

- I would like to expand my farm to offer U-pick services for fruits and vegetables.

- I would like to make a bigger and better farm that I currently own with more quality beef cattle and produce.

- I would like to produce chemically-free meat and produce for my family and have the farm provide enough income so I would not have to work off-farm.

- I would like to raise a garden in order to provide food for canning and have enough for the winter months and raise animals in order to have meat and I also enjoy taking care of animals and watching things grow.

- I would like to raise more produce to sell to more people my goal is to make a min of 5000 out of my garden

- I would like to raise produce to can to help feed my family and to help other have fresh produce.

- I would like to start a licensed creamery and/or farm full time with income generated from the farm supplementing my husband's income

- if the good lord above gives me a good honey year, I will double my bees, and make a little money.

- im 88 years old so my farming and garden days are about over

- improve production by maintaining better soil. Provide more marketable wood products from steeper and rougher areas. Try for more value-added products.

- improve the poor land areas in order for it to be more productive

- improved landscaping; replace fences; maintain timber properly.

- Income from small fruit that will pay for all farm activities. Grow $90 \%$ of the food we eat. Help the local economy. Provide education for other gardeners.

- Increase all crops by 10 percent and add a few new ones.

- Increase my food production by $25 \%$ this year, increase my orchard by $25 \%$, make a berry patch, be able to can and freeze produce to off set cost of food this winter

- increase number of berry plants and fruit trees. Increase number of beehives

- Increase production \& expand the farm

- increased productivity with totally organic methods

- it is our hobby

- it is work that $i$ enjoy 
- it where I want to raise my family and I would like to expand my sheep and ginseng operation.

- Just do it. No real goals.

- just enjoy it

- just to have my own chemical free vegetables

- keep deer out

- keep in the family.

- keep land clean and useable

- keep on raising our food

- keep things in the black and to expand on herd size

- land over to family

- leave farm to my kids

- locate and develop markets for my cut flowers and vegetables; diversify farming enterprises, increase yearly income over next 3-5 years

- Lots of lettuce for the summer and some greens to freeze. Lots of tomatoes to eat and can. Lots of green beans or eat and can and freeze. Other crops are a bonus.

- love to do it.

- make an income with crops if there is an abundance but primarily to have my own food source

- make some income, participate in local farm market

- manage 1.5 acre in diversified crops of fruits, berries, and annual vegetables. Produce on-farm $100 \%$ fertility through worm composting operation and cover cropping. Employ irrigation system and greenhouse in future expansions.

- maybe one day being able to produce enough produce for the farm to school.

- means of providing food for family and supplementing retirement income.

- more animals per acre on pasture

- more raised beds and hoophouse help my daughter to work her land.

- mostly adequate fresh vegetables for summer and also potatoes for winter some vegs to freeze - excess to farmers market

- My farm would ideally provide food and income when I retire.

- My garden and farm are organic(not certified) as I strongly want my garden vegetables that I eat, share and can to be clean and healthy.I want the same freedom from chemicals for my cow/calf operation.

- my garden is for home use. Excess produce is given to friends and family. Some is donated to food pantries I do not sell produce.

- my garden will produce vegetables for my family and additional products for the farmers market, eggs, baked good, and produce. We also process sausage.

- My garden will provide my family with fresh and healthy vegetables.

- my gardening is a happy and fresh for family

- My gardening is a hobby, No one can buy a farm and equipment these days and turn a profit in WV. Its something you have to enjoy

- my goal - to continue gardening as long as the good lord allows me the strength. This may be the last year.

- my goal has been reached. I have always wanted a farm. I make hay and now have decreased my herd of cattle. 
- my goal is to pass the farm down to my children

- my goal is to produce a good quality product. Whether to be hay or vegetables.

- my goal is to produce healthy food with as little use of chemicals as possible. I plan to expand my farm produce

- My goal is to produce high quality food as a supplemental income.

- My goal is to produce strong plants that are nourished by the soil, which will, in turn, nourish the people who consume these foods. I wish to work in harmony with nature, not against it. I am 100\% dedicated to organic standards but do not support USDA's weak organic standard.

- my goal is to provide fresh food for my family and friends and others if crop produces well.

- my goal is to provide my family with good food (chemical free) throughout the year and to save on the cost of groceries

- my goal is to raise and sell produce grown using organic farming methods.

- my goal is to raise angus beef and make hay to sell mostly to people with horses

- My goal is to utilize the 45 acres we have here in a productive way rather than just mowing everything. To be able to offer the community through a farmers market plus this year on farm sales of good vegetables, garden plants and cut flowers.

- My goals are for my garden and farm to provide high quality food products at a lesser cost than can be obtained at a store.

- my goals are to provide wholesome, healthy food for my family, reduce costs at grocery store, provide healthy choices for my farm market friends, supplement my retirement check and get outside in the air and sunlight.

- new ground for potatoes and corn

- no goals - 70 years old

- one day we will make it a full time job

- Operate fiber farm and hay and corn and herbs and vegetables

- our family will continue in the angus cattle business. Want to make a profit

- Our goal is to continue to expand our CSA in a way that nourishes the land and our customers, while carving our a unique or niche product market to help sustain our farming operations.

- Our goal is to raise food for family and friends, naturally and locally, without chemicals.

- $\quad$ our goals are to feed our family. We no longer raise sheep.

- part time resident of the state I raise a garden and have honey bees as a hobby. My gardening is organic

- $\quad$ pass the family farm to the next generation in a more productive state then when I received it while also supplementing my retirement income

- $\quad$ pay our taxes with a little left over

- $\quad$ pay the bills there is $\$$ out there to be made and I love it.

- plan to continue to grow food without chemicals for my families health.

- $\quad$ plan to farm and garden till death do us part

- plan to raise beans cabbage pepper onoins tomatoes, cucumbers squash corn broccoli, cauliflower, etc.

- Plan to slowly back off farming because of age - head says yes body says no

- Planning on retirement 
- plant vegetables and eat them

- Presently raising/developed under my planned guideline Reg. Black Angus cattle as seedstock. Will in the very near begin raising/developing a flock of sheep as seedstock. The greenhouse will be utilized to extend growing season for our vegetable garden. Have in the past participated in local farmer markets and sold produce directly off the farm. There is no income from off farm occupation that is used to operate these ventures. Farm must support itself.

- $\quad$ produce 1 acre of blueberries and $1 / 2$ acre truck crop and be profitable

- $\quad$ produce a profit that would equal the take home pay I would receive from an off-farm job; pay the real estate taxes and insurance on the farm, and provide food for personal use.

- $\quad$ PRODUCE AND EAT LOCAL HEALTHY FOOD

- $\quad$ produce at least $50 \%$ of our own food. Produce at least $75 \%$ of our income. Increase value of our land by TSI and perennial crops

- $\quad$ produce enough food for family and sell excess

- Produce enough non GMO vegetables to last the whole year, for four households.

- $\quad$ produce enough to off-set food prices

- $\quad$ produce enough vegetables to feed my family and 10-15 other families

- Produce food for household to decrease grocery purchases. Preserve enough food to significantly offset food purchases year-round. Continue to improve our knowledge of growing techniques. Undertake work which is physically and emotionally satisfying. Continue tradition. Be part of a community of food producers.

- $\quad$ Produce food for my family and sell any surplus at farmers markets.

- $\quad$ produce food for our own use in the home.

- $\quad$ produce foods for sale in the local farmers market and farm to school to promote locally grown

- produce garden vegetables for home use/canning. Be a good steward of land/pasture/hayland activities with consideration to conservation and wildlife.

- $\quad$ produce high quality food w/out chemicals, plus unique varieties

- $\quad$ produce more of my own food each year

- $\quad$ produce most of our own food

- $\quad$ produce own/wholesome food. Supplement income, get outside, exercise

- $\quad$ produce personal food and show rabbits

- produce significant amounts of food for home use to reduce exposure to harmful chemicals and to live organically.

- $\quad$ produce to participate in farmers market if all goes well.

- produce vegetables and Angus beef for sale to local customers

- $\quad$ productive orchard to care for the best of my ability

- promote and grow heirloom non-roundup ready varieties, preserve biodiversity rare and endangered/use integrated pest management and no-till techniques.

- $\quad$ Provide a wide variety of fruits, vegetables and beef that are appetizing and safe for my family.

- Provide all meat and seasonal vegetables for our family. Make some additional income in the summer months by selling excess produce. 
- $\quad$ provide extra income (w/profit)

- $\quad$ provide food for myself and some for extended family. Some income.

- $\quad$ provide for myself, store foods, and livestock products

- $\quad$ provide fresh food for my family. Save money by doing this.

- Provide fresh meat and vegetables for family

- $\quad$ provide fresh produce for family

- $\quad$ provide good food for good health

- $\quad$ provide good produce for family and possibly sell surplus

- Provide healthy food for family and friends and someday expand it into a business.

- $\quad$ provide healthy food for my family; provide fresh produce and meat to others; make money

- Provide home raised food for family consumption and turn a profit on farm related expenses.

- $\quad$ provide my family with home grown produce/ meat for family consumption. Enrich my life in a rural country setting.

- $\quad$ provide nutrient dence food, sell some produce at farmers market, spend my last days on MY farm. Born on one and like to die on one.

- $\quad$ provide quality food and income

- Provide quality food for local consumption.

- Provide quality food, be sustainable, and be environmentally conscious.

- $\quad$ provide vegetables and meat for my family as well as others

- $\quad$ raise best food without chemical and herbicide

- $\quad$ raise eat and sell natural local food

- $\quad$ raise enough food for canning to last all winter and share with family members and friends

- Raise enough for family and others, new raised beds as old ones were demolished in construction, more fruit trees and nut will be planted in the coming year.

- raise enough to last from one summer to the other with extra that I can give away

- $\quad$ raise food for 4 families; can food for all have a better variety of things to offer.

- raise fruits and vegetables for my wife and I and my childrens families

- $\quad$ raise healthy happy poultry; raise vegetables that aren't GMO, with as little chemicals as possible.

- $\quad$ raise it for the enjoyment of growing and enjoy the fellowship at the market

- $\quad$ raise my children around gardening/farming, raise fresh healthy food for my family. Any $\$$ made from farming/gardening is a plus.

- $\quad$ raise produce,beef,and honey for my own use and also to try to sell.

- raise quality food - have fun - and earn some extra money providing food to the public through the farmers market

- raise quality food for my family and those who appreciate a chemical free product

- $\quad$ raise quality fruits and veggies for home use and sale

- raise some produce for home consumption and provide experience for grandchild

- $\quad$ raise sweet corn; to sell at farmers market 
- $\quad$ Raise the garden beter \& chemical free

- $\quad$ raise vegetables to use at home and enjoy gardening

- raise what my family and I use and a little extra to sell for a little income

- raising beef cattle and a vegetable garden

- recreation

- self sustainable with income coming in

- $\quad$ self sustaining and enjoyable

- $\quad$ self sustaining life

- $\quad$ self-preservation and environmental improvement and sustainability.

- $\quad$ self-relientcy, improve soil.

- $\quad$ self-sufficiency

- $\quad$ self-sufficient sustainable system aka to perfect my natural farming system

- $\quad$ self-sufficient; be able to grow my own food. Raise my own animals, be a benefit to a local farmers market

- $\quad$ self-sustaining organic vegetables. I use a French intensive green manure technique.

- $\quad$ sell farm produce to community. Healthful and gives some extra income on given years

- Short term overall goal is to develop both institutional and retail customers at a profitable level. Long Term (less than 5 years) to provide a full time professional level salary to our family.

- $\quad$ small back yard garden; eat what produce and sell excess at farmers market and others

- $\quad$ some day make a profit

- Some income but mostly satisfaction of raising food for ourselves and people we know. Also fun and community in working together.

- $\quad$ stay busy and enjoy the outdoors

- $\quad$ stay in business a little while longer

- Successful CSA. Excellent crop yields and good animal husbandry

- $\quad$ successfully growing our now 2 year old greenhouse business. To also incorporate high tunnels to increase food production for sale at markets.

- $\quad$ supply enough food to feed my family of 5

- Support local resilient community and provide fresh local toxin free foods

- $\quad$ support our community by creating a sustainable farm that generates income for our family. Areas of interest are: aquaponics, silviculture, and value added products

- $\quad$ sustainable

- $\quad$ sustainable grown using organic principles healthy free range animals/livestock

- I want to make available for market vegetables not usually seen in march and october by using low tunnels.

- To acquire more small lots of land within the downtown area so that my farm increases in size, yet remains right in the center of the city.

- to be a better one of the small farms in the area

- to be a full-time farmer, to build it up to be able to use $90 \%$ of the land for garden, pasture, etc. to be commerced and well-known. 
- to be a larger operation to provide steadier income year round

- to be able to at least maintain my size and or grow when I retire from my full time job

- to be able to can my garden veggies and be able to take some to farmers market

- to be able to can, freeze, dry enough food to feed my family for a year without buying groceries.

- To be able to clear enough land to be able to produce enough lettuce, cucumbers, potatoes, etc for Farm to School. For my high tunnel we plan to grow greens and lettuces year round and grow strawberries in hanging baskets to sell at the farmers market. Another goal we have is to clear off enough land to grow black raspberries to sell.

- To be able to eat what I grow and to sell the remainder for extra income

- to be able to feed my family from the garden and not buy from store

- to be able to raise enough to freeze to last all winter

- to be able to sell what we grow as it is produced. To increase the family's income.

- to be as chemical free as possible

- To be continuing, profitable business

- to be diversified enough to have some income all year, and for the farm to make enough to take care of me and mine.

- to be one of the top small farms in our area.

- to be productive as a food producer and protector as an environmentalist and keeper of the land - we own nothing. We only use things for a period of time

- to be profitable and be able to do the things I want to do.

- to be profitable enough to keep it in farming or gardening.

- to be profitable/sustainable with sufficient income to support me/family. I also enjoy it I've done it virtually all of my life. We've generally made money but the margins are low - other things have helped like timber sales, pipeline row, gasoil leasing and royalties

- to be self-reliant. To leave our farm better than we found it. To utilize our natural resources and improve them.

- to be self-sufficient and able to generate an income w/ farming. To utilize our land to its potential

- to be self-sufficient and make decent income

- to be self-sufficient and to enjoy farming more in retirement as well as teach our grandchildren about farming and gardening

- to be self-sufficient. Teach my boys ethics and how to work and appreciate those that do. Eventually pass the entire operation over to our boys.

- To become more self-sustainable, raise more niche crops and specialty crops that have less competition for higher revenues and increase value added commodities such as canning excess produce for sales over wintering.

- to become self-sufficient without the need for off-farm job to supplement income.

- To bring the soil, land and surrounding environment into balance by increasing fertility and visual beauty to create a harmonic blending of all aspects of nature for eventual self-sustaining stewardship. As this is achieved, the end result will encourage and promote others to learn to accomplish similar results.

- to continue the family beef farm 
- To continue to be a good steward of the land by using the many techniques and knowledge that makes it profitable and enjoyable and environmentally sound.

- to continue to be a self-sustainable operation.

- to continue to dairy, beef, and vegetable farm. TO SURVIVE. To raise kids to know responsibility and hard work and money management and how fortunate we are to have our farm and good food that we raise. Probably stay the same size so we can manage it as a family. maybe raise more produce, currently raise sweet corn and beans for market.

- to continue to garden as long as I possibly can to provide healthier food for my family and friends (it is good exercise for me and my family that helps).

- to continue to grow as much of our own food as possible and to provide local restaurants a choice of high quality fresh produce.

- to continue to have fresh beef to butcher, fresh eggs, produce out of our garden to can \& eat fresh

- to continue to increase my production of food to feed myself and to have extra to sell

- To create a self-sustainable(or as close as possible) farm of both plant and animal resources while selling excess in local community.

- to create a viable business and provide quality products for the local community

- to develop a good diversified vegetable garden and at least one high value niche product.

- To develop goat cheese, milk, and icecream that will change the public's view of goat dairy products. This will intern give the public a better choice for healthier living.

- to eat healthy

- to enjoy the food I've grown in the wintertime

- to expand my market gardening of fruits and vegetables to include pigs and other livestock. Increase my chicken flock to about 20 and add ducks

- to expand my present business I have owned and operated part time for 29 years as a full time business.

- to generate enough income to get by on.

- to grow as much organic or naturally grown food for my table as possible

- to grow chemical free produce

- to grow chemical free produce (including non-GMO seeds) for my family, and provide an extra supply to sell.

- to grow enough for family needs and share or sell my extras

- To grow my own chemical free food and share the excess with others. Plant blueberries. Expand shiitake mushroom operation.

- To grow own food for the household for summer eating, can food for winter months, and sell some at market

- To grow produce for family and friends.

- TO GROW SUFFICIENT FOOD FOR MY WIFE AND MYSELF AND SELL ENOUGH EXTRA TO CONTINUE EAACH YEAR WITHOUT ADDITIONAL INVESTMENT FROM OTHER INCOME SOURCES.

- to have an extra income by selling produce from my high tunnel

- To have farm operation enrich our soils and lifestyle.

- TO HAVE FRESH VEGETABLES/FRUIT

- To increase beef and food production by $50 \%$ in the next 10 years. 
- $\quad$ to increase net profit with diversifying what I grow and sell

- to increase production on both farm and garden

- to install at least 1 high tunnel; to build a new barn

- to keep farm operating as a farm.

- to keep it stable enough to pay bills and live comfortably.

- to keep producing as long as possible

- to leave my farm to my children and nephew in better condition (land and buildings) than when I received it from my parents.

- To maintain my farm/land to the best of my ability while I am here and then to pass it on to my children

- to make ends meet and live a comfortable lifestyle on just the farm; income alone for myself and my parents.

- to make income

- to operate a viable business and turn the farm over to my family.

- to pass the farm onto the family. Instill a work ethic in my family; help the local economy

- to plant a large garden for my own use and sell the surplus.

- $\quad$ to produce a good marketable product that lets me make a good living.

- To produce a healthy product for our customers, provide ourselves with additional income, harvest and preserve fruits and vegetables for our family, be good stewards of our land.

- to produce a profit every year and pass the farm on to my family.

- to produce a quality beef cattle operation that generates a high quality, high yield angus beef product as well as productive cows and bulls

- to produce as many lambs as possible, with a minimum of chemicals (they still come in the grain) and with no predator loss

- to produce enough food for our use and to share. Enough hay to break even.

- To produce enough food to comfortably survive and to be able to expand the marketing to consumers as my knowledge and capacity permits and depending on the demand.

- to produce enough healthy vegetables for our use as well as to share/sell to others

- to produce food that is healthy for all.

- To produce fruit and vegetables for income and to make good, nutritious and healthy food to my community.

- To produce good safe food and make. a reasonable profit.

- To produce healthy food for myself and others. To maintain my land responsibly with as little environmental degradation as possible.

- To produce quality produce to sell locally at my family farm market

- to produce quality products so our customer come back; next season. To generate enough income to cover the ever-increasing cost of farming and to make a profit

- To produce sustainably and provide my family with a valuable second income stream, while connecting with the community and acting as a good steward to the environment.

- to produce the best quality angus cattle possible, to be able to farm and pass it on to the next generation.

- To produce the best quality food we can, feeding others and ourselves well, and making a living in the process 
- To produce/process a variety of vegetables, small fruits and herbs in order to maintain health, deal with minor health issues. To educate others so they can raise food crops successfully. To share foods and recipes c/ others so they enjoy healthy dining. To make enough money selling produce $\&$ value added products to pay the basic farm bills [supplies, etc.]

- to promote family health by providing a reliable source of nutritious, non-toxic plant products

- To provide a major portion of my food year round organically.

- to provide a peaceful place to relax and enjoy the nature of producing the food you consume.

- To provide a source of exercise and enjoyment in the outdoors. To provide a level of self satisfaction. To produce flavorful and healthy fresh and processed food. To supplement our home food supply and lower our annual food bill.

- To provide additional income and to maintain my property to be economically and aesthetically valuable

- to provide affordable quality fruit to consumers

- to provide chemical free food products. To be outside with my animals and garden. To touch others.

- To provide economic support for my family and to enhance the health of my community.

- to provide food and extra income for family.

- to provide food for my family.

- To provide food that we enjoy and grown in a manner that I know will provide good health. I like to know what I eat.

- to provide food, income, self-fulfillment, work ethics for future generations.

- to provide for my family and customers at our restaurant. To take care of the legacy of our family farm and orchard. Four generations strong.

- to provide for my family and friends by producing a healthy food source and sell enough to pay for my own as well.

- To provide fresh chemical free meat and other food products to my family and provide enough income to stop working off the farm.

- to provide fresh food for the farmers market and schools and to put up for us

- to provide fresh produce for family use and enough extra to sell at farmers market. To earn enough to off-set costs for garden.

- to provide fresh, clean food for my family and community as well as to provide income

- to provide healthy cost-efficient food for my family and others and to pass on the tradition

- to provide healthy good food to our local area, also to provide vegetable starts for our community to grow their own garden. We also grow quality mums and spring hanging baskets. We are on our way of having the farm providing $100 \%$ of our financial income.

- to provide high quality food, milk and cheese and eggs for my family.

- To provide Honey, Fruit, Produce, and meat for family and for sale at local Farmers Market and calves for market

- To provide myself, friends and family members with tasty produce and meat without preservative and hormones and as few pesticides as possible.

- to provide organic food for my family and others. I would like to increase the amount of fruit in my garden (blackberries, blueberries, etc.).

- to provide organic food stocks to the community and help sustain farming as a viable way of life

- To provide organic fruits and vegetables for family consumption and to grow an orchard through espalier and cordon methods. 
- to provide superior nutritional product at affordable prices for WV working families. Sustainable farming practices, no GMO, no chemical or biosolids fertilizers, you are what you eat.

- to put the best quality produce on the local market

- to raise a garden as long as I am able

- to raise a good crop of anything that helps pay the bills of the farm or household

- to raise berries and honey bees

- to raise cattle w/out going into the red

- to raise crops that satisfy property tax requirements. Raise high quality vegetables. Raise crops that a small gardener is unable to raise in any quantity such as beans, corn and potatoes.

- to raise enough food to meet our needs without needing to go to the grocery store.

- To raise enough for all our family and sell at farmers market.

- to raise enough to can or freeze for our use, and to sell some vegetables at the farmers market

- To raise enough to help feed my family and know what I am eating and where it came from. We can some of our produce and freeze it so we can eat it year round.

- to raise enough to support family, farmers market, and farm to school.

- To raise enough vegetables for my family for the year. I hope to be able to expand into production eventually.

- to raise food for myself and family and friends

- to raise food so that I am not dependent on grocery stores for our main source of food

- to raise lambs and garden crops in a sustainable manner while providing income for the family. It is also a 'way of life'.

- To raise meat, vegetables, and herbs that are free from chemicals. To raise our sheep in a humane way and to have them raised on pasture. Encourage others to use herbs more in their cooking and for medicinal purposes.

- To raise most of the food we eat year round. To sell quality food to the local market. To enhance community via gardening.. To be an example of what is possible.

- to raise my animals and garden as natural as possible without chemicals and to become as self-sufficient as i can

- to raise my family with a good work ethic and respect for the land and animals and to make a little money

- to raise produce and sell at local tailgate market and or customers locally.

- to raise the very best. Good, fresh, and safe.

- to raise vegetables for canning and table use as tomatoes, beans, corn peppers etc to sell at the local market

- to retire to farming in $2.5 \mathrm{yrs}$ then expand - beef cattle herd

- To safely produce a product that can help feed our food chain in America. Pass on the value of good and strong work ethics to the younger generations.

- To see that it continues to improve over the years.

- to sell produce at farmers market. To raise quality crops that would have value. To have quality foods for my family. 
- To slowly generate an adequate income where it may be possible in the future to solely concentrate on farming as a business; This can be done by helping to educate the population on the reasons why to buy local food; Pursue a variety of different buyers such as restaurants, schools or CSAs.

- to slowly grow more products

- to succeed

- to supply family with economical and healthy food

- To supply our family needs with food and improve the quality of our soils, pasture, and forest.

- to sustain soil value and to consume healthy foods

- to teach grandchildren the value of knowing where their food comes from

- to try to produce more crop to can for winter months

- to turn it into a multigenerational enterprise that can eventually be self-sustaining and support us all; and to become a place where others can come to learn to do the same. To try and live by permaculture principles.

- too involved

- Transitioning to organic fruit and vegetable garden for local direct marketing

- try to keep deer and vandalism at bay so we reap a better crop.

- try to make a decent living

- try to produce a quality crop

- try to raise more organic food.

- trying to expan as moneyis ababl

- Use land to provide a product not readily available from other local growers

- vegetable and fruit farmer - advocate total abstinence from beef production

- want a wide variety of vegetables and fruit; developing 2.5 acres as I can

- want to grow unusual food to sell at farmers market. Have enough produce to can and freeze for my family. Usually around 300 qts. Raise enough potatoes to last the whole market.

- we are currently preparing for a berry farm operation, have just recently sent plans for an on farm creamery to the state, and currently supplement the farm with goat's milk soap and maple syrup and maple products.

- we are in our senior years but we plan to raise enough vegetables to feed overselves plus some.

- we are only a family gardnener raising potatoes, corn, beans, etc. for our own use.

- We are retired and raise almost all our own food. Love it. Really wish my city kids and grandkids had the opportunity and desire to do this also.

- we grow and can to feed family and friends

- we hope to raise enough food to eat and can some. But its getting more limited each year as I am 80 and my husband is 82 .

- we plan to expand the size of to raise more produce, also plan to raise laying chickens for eggs to sell.

- We plan to raise mushrooms this year as something new. Add a new raised bed. Look Into building our 1 acre pond.

- we plan to raise vegetables and plants for sale and our use. 
- we plant a garden so we can can and freeze food for winter time

- We produce fruits and vegetables for our personal use and then sell or share what we cannot use. We want to establish a new fruit orchard with pears, apples and nuts. We know that these trees will take a few years or longer to produce but hope to pass them on to someone else. We have blueberries that are grown without chemicals and sell what we don't use. We are going to increase the number of plants we have and want to participate in the Farm to School program and local farmers market.

- we share the produce and can vegetables for later use

- we want our daughter to know and understand where food comes from.

- We want to make a living at home while we provide fresh, local produce to the community.

- we would like our farming ventures to support the family; with minimal offfarm income by 2015.

- we would like to grow around 30 items in our garden. Usually we grow one thing we've never tried. This year it is stevia.

- we would like to have different operations set up so that our children and grandchildren can step in and improve after we are gone.

- we would like to increase our herd up to 100 sheep and 60 head of cattle

- well I will be 70 yrs old this fall some mornings I don't feel like getting out of bed. I would crawl up to that garden to plant vegetables

- whole diet CSA sustaining 40 families, growing the dairy, four season production.

- $\quad$ would hope trees produce enough fruit to sell. Would like to sell corn and potatoes. Would like to reture and live off the farm and make a decent living.

- $\quad$ would like to achieve as low of a turn around of goods (travel/transport) as possible. Less expenses = less work(income)=less stress.

- would like to grow enough food to provide for my family and to sell the extra at the farmers market to help pay for the cost of supplies for garden

- would love to have it be a part of society where work and land would be a part of sustainability toward maintaining life.

- God who makes all this possible. My goal to do as much as I can as long as I can. 
Question 6. "How many of the following did you raise in 2012 and how many do you plan to raise in 2014, two years from now?"

All producers were asked to answer this question. In this table, SUM refers to the total aggregate number. Due to inconsistencies in producer responses about number and scale of fruit and berry plants, it was not possible to aggregate data that reflected number of plants. Instead, producers who indicated planting any berries or fruits, were coded as " 1 " and if they did not plant those, as " 0 ". Therefore, the berry and fruit data only reflects whether the producer had any or none at all, and not a number. 


\begin{tabular}{|c|c|c|c|c|c|c|c|}
\hline Description & DATA CODE & $\mathbf{N}$ & MEAN & $\begin{array}{l}\text { STD. } \\
\text { DEV }\end{array}$ & MIN & MAX & SUM \\
\hline Number of calves 2012 & CALF12 & 545.00 & 1.22 & 28.75 & 0 & 275 & 5791 \\
\hline Number of beef calves 2014 & CALF14 & 506.00 & 13.21 & 43.82 & 0 & 700 & 6686 \\
\hline Number of fattened beef 2012 & BEEF12 & 552.00 & 1.98 & 14.07 & 0 & 200 & 1092 \\
\hline Number of fattened beef 2014 & BEEF14 & 503.00 & 2.38 & 14.92 & 0 & 200 & 1196 \\
\hline Number of broilers 2012 & BROILER12 & 552.00 & 1076.25 & 23078.11 & 0 & 540000 & 594089 \\
\hline Number of broilers 2014 & BROILER14 & 506.00 & 1190.15 & 24103.74 & 0 & 540000 & 602214 \\
\hline Number of layers 2012 & LAYER12 & 554.00 & 104.61 & 1565.20 & 0 & 28000 & 57953 \\
\hline Number of layers 2014 & LAYER14 & 502.00 & 121.22 & 1644.46 & 0 & 28000 & 60850 \\
\hline Number of piglets 2012 & PIGLET12 & 553.00 & 1.25 & 13.41 & 0 & 300 & 689 \\
\hline Number of piglets 2014 & PIGLET14 & 506.00 & 1.77 & 14.75 & 0 & 300 & 898 \\
\hline Number of pork 2012 & PORK12 & 554.00 & 0.34 & 2.30 & 0 & 47 & 190 \\
\hline Number of pork 2014 & PORK14 & 505.00 & 0.82 & 5.70 & 0 & 100 & 413 \\
\hline Number of lambs 2012 & LAMB12 & 554.00 & 3.19 & 19.75 & 0 & 300 & 1770 \\
\hline Number of lambs 2014 & LAMB14 & 506.00 & 5.21 & 39.75 & 0 & 750 & 2634 \\
\hline Number of meat goats 2012 & MGOAT12 & 554.00 & 3.45 & 67.22 & 0 & 1580 & 1910 \\
\hline Number of meat goats 2014 & MGOAT14 & 507.00 & 6.67 & 133.28 & 0 & 3000 & 3381 \\
\hline Number of dairy cows 2012 & DCOW12 & 554.00 & 0.86 & 8.04 & 0 & 100 & 479 \\
\hline Number of dairy cows 2014 & DCOW14 & 507.00 & 0.87 & 8.08 & 0 & 100 & 443 \\
\hline Number of dairy goats 2012 & DGOAT12 & 554.00 & 0.28 & 2.21 & 0 & 28 & 153 \\
\hline Number of dairy goats 2014 & DGOAT14 & 506.00 & 0.39 & 2.80 & 0 & 40 & 196 \\
\hline Number of fruit trees $2012(*)$ & FRUIT12 & 563.00 & 0.48 & 0.50 & 0 & 1 & 270 \\
\hline Number of fruit trees $2014(*)$ & FRUIT14 & 529.00 & 0.55 & 0.50 & 0 & 1 & 290 \\
\hline Number of berry plants $2012(*)$ & BRY12 & 564.00 & 0.48 & 0.50 & 0 & 1 & 268 \\
\hline Number of berry plants $2014(*)$ & BRY14 & 525.00 & 0.54 & 0.50 & 0 & 1 & 286 \\
\hline Number of vegetable acres 2012 & VEGACRE12 & 520.00 & 1.04 & 2.73 & 0 & 27 & 539 \\
\hline Number of vegetable acres 2014 & VEGACRE14 & 425.00 & 1.32 & 3.54 & \begin{tabular}{l|l}
0 \\
\end{tabular} & 35 & 562 \\
\hline
\end{tabular}


Responses under "Other" and Comments, $N=44$

- 1 ton wine grapes

- 100 acre hay corn alfalfa sorghum

- 126000 turkey

- 2 bee hives

- 2500 rainbow trout

- $326 X 150$ greenhouses with plants

- 3 turkeys

- 30 turkeys

- 4 acre corn

- $6000 \mathrm{sq} f \mathrm{ft}$ greenhouse

- agritourism

- assorted herbs

- bee hives; 600 maple taps; 3 turkeys

- chestnuts

- christmas trees

- currants

- ducks

- ducks, maple syrup, bees

- elderberry 2

- field corn

- flowers

- greenhouse plant production; 2 greenhouse

- ginseng; mushrooms

- grains

- herbs

- honey

- honey

- honey bees

- honey bees

- maple syrup

- meat rabbits

- mums

- mushroom

- mushrooms

- nuts

- persimmon:500

- rabbits

- rabbits

- shitake

- sunflowers

- sunflowers

- trout

- wineberries, nectarine

- wood products 
Question 7. "Which of the following best describes your food production plans for the next 2 years?"

All producers were asked to answer this question. In this table, SUM refers to the total number of observations coded as " 1 ” for each item. $\mathrm{N}=546$

\begin{tabular}{|c|c|c|c|c|c|c|}
\hline Description & DATA CODE & MEAN & $\begin{array}{l}\text { STD. } \\
\text { DEV }\end{array}$ & MIN & MAX & SUM \\
\hline I plan to produce more overall. & EXMORE & 0.47 & 0.50 & 0 & 1 & 257 \\
\hline I plan to produce the same amount overall. & EXSAME & 0.38 & 0.49 & 0 & 1 & 208 \\
\hline I plan to produce less overall. & EXLESS & 0.06 & 0.24 & 0 & 1 & 34 \\
\hline I plan to stop farming or gardening entirely. & EXSTOP & 0.01 & 0.12 & 0 & 1 & 8 \\
\hline I am not sure. & EXUNSURE & 0.08 & 0.27 & 0 & 1 & 44 \\
\hline
\end{tabular}

Question 8. "Please estimate what percentage of your diet is made up of food products that you raise."

All producers were asked to answer this question.

\begin{tabular}{|l|l|r|r|r|r|r|}
\hline Description & DATA CODE & MEAN & \multicolumn{1}{|c|}{$\begin{array}{l}\text { STD. } \\
\text { DEV }\end{array}$} & MIN & MAX & SUM \\
\hline $\begin{array}{l}\text { Percentage of diet made up of food products that you } \\
\text { raise. }\end{array}$ & DIET & 0.43 & 0.27 & 0.00 & 1.00 & 228.35 \\
\hline
\end{tabular}


Question 9. "Do you use any of the following terms to describe the food products that you raise? (Please check all that apply)."

All producers were asked to answer this question. In this table, SUM refers to the total number of observations coded as " 1 " for each item. N=555

\begin{tabular}{|l|l|r|r|r|r|r|}
\hline Description & DATA CODE & MEAN & $\begin{array}{c}\text { STD. } \\
\text { DEV }\end{array}$ & MIN & MAX & SUM \\
\hline Grass-fed animals & GRASSFED & 0.33 & 0.47 & 0 & 1 & 183 \\
\hline Free-range animals & FREERANGE & 0.26 & 0.44 & 0 & 1 & 144 \\
\hline Organic & ORG & 0.21 & 0.41 & 0 & 1 & 115 \\
\hline Certified organic & CERTORG & 0.01 & 0.09 & 0 & 1 & 5 \\
\hline Naturally-grown & NATGROWN & 0.54 & 0.50 & 0 & 1 & 297 \\
\hline Certified naturally-grown & CERTNATGR & 0.02 & 0.13 & 0 & 1 & 10 \\
\hline No spray/pesticides & NOSPRAY & 0.30 & 0.46 & 0 & 1 & 169 \\
\hline Certified humane & CERTHUMAN & 0.06 & 0.24 & 0 & 1 & 35 \\
\hline Other & LABOTH & 0.12 & 0.32 & 0 & 1 & 64 \\
\hline
\end{tabular}

\section{Responses to “Other”, Question 9, N=59}

- age/source-verified precondition feeder cattle

- animal welfare approved

- antibiotic free

- biodynamic

- bqa source and age verified.

- chemical free

- chrysanthemums

- do not use any of above

- farm fresh

- fresh

- grain fed, organic, locally produced, fresh, good tasting

- grain-fed beef

- grain-fed beef, no hormones

- herbs

- homegrown

- homegrown
- homegrown

- homegrown

- homegrown

- homemade pest control

- humane

- hydroponic

- $\quad \mathrm{i}$ use fertilizer and pesticides as needed

- ipm grown

- limited pesticide usage

- local, ask me how i raised it

- local, tree ripened

- locally grown

- locally grown

- locally grown

- locally grown

- locally grown, using organic methods 
- locally raised

- looking to get animal welfare approved certification

- minimal chemical use; i'm a bee-keeper

- minimum pesticides

- no gmo seeds or feed

- no nasties!

- pastured

- quality (...)

- reduced spray

- responsibly grown

- $\quad$ spray when needed

- sprays and fertilize

- sustainable

- sustainable

- sustainable

- sustainable
- $\quad$ sustainable agriculture

- sustainable agriculture and ipm

- $\quad$ sustainably produced

- unless no choice with heavy infestation usually only potato bug

- use organic pesticides such as bt

- very little spray or pesticides only what is necessary for blight and bugs

- we describe processes to our customers, since we do not pay the government for the privilege of using terms that tell how we have always grown our food [organic since the 70s].

- we try to be as organic as possible and to use natural pesticides whenever possible

- we use pesticides, fertilizer, and lime

- webster county grown

- would like to try organic 
Question 10. Which of the following marketing outlets do you plan to sell through sometime in the next two years? (Please check all that apply).

All producers were asked to answer this question. In this table, SUM refers to the total number of observations coded as "1" for each item. $N=553$

\begin{tabular}{|l|l|r|r|r|r|r|}
\hline Description & DATA CODE & MEAN & $\begin{array}{c}\text { STD. } \\
\text { DEV }\end{array}$ & MIN & MAX & SUM \\
\hline Markets: None & MKTNONE & 0.15 & 0.36 & 0 & 1 & 85 \\
\hline Farmers market & MKTFM & 0.58 & 0.49 & 0 & 1 & 318 \\
\hline Roadside Stand & MKTRS & 0.26 & 0.44 & 0 & 1 & 145 \\
\hline Processor/Finisher & MKTPROCFIN & 0.05 & 0.22 & 0 & 1 & 29 \\
\hline Restaurants & MKTREST & 0.18 & 0.38 & 0 & 1 & 99 \\
\hline Vegetable Auctions & MKTVEGAUC & 0.03 & 0.16 & 0 & 1 & 15 \\
\hline Community Supported Agriculture (CSA) & MKTCSA & 0.08 & 0.27 & 0 & 1 & 42 \\
\hline Grocery Stores & MKTGROC & 0.10 & 0.29 & 0 & 1 & 53 \\
\hline Live animal stockyard/buyer & MKTSY & 0.27 & 0.45 & 0 & 1 & 151 \\
\hline Schools & MKTSCHOOL & 0.14 & 0.35 & 0 & 1 & 79 \\
\hline Hospitals & MKTHOSP & 0.01 & 0.10 & 0 & 1 & 6 \\
\hline Not sure & MKTUNSURE & 0.05 & 0.23 & 0 & 1 & 30 \\
\hline Other & MKTOTH & 0.18 & 0.38 & 0 & 1 & 76 \\
\hline
\end{tabular}

\section{Responses under “Other”, Question 10, N=74}

- $4 \mathrm{H}$ and FFA Fair

- acquaintances

- an online market, not a traditional farmers market

- any interested

- bakery

- County calf pool-- via WVU Extension Service

- DIRECT FROM FARM

- direct sales from farm - change to roadside/onfarm then??

- Direct sales to individuals, my fastest growing business
- direct to consumer

- door to door, neighbors

- energy express most likely a donation

- ethnic buyers

- ethnic self-slaughter on farm

- farms/farmers/families

- feed store

- flea markets

- florists 
- for our family and neighbors

- for own use

- friend

- friends

- friends and neighbors

- from home and deliver to a handicap seniors

- gift shops

- gifts to others

- give away to non-profit organization

- give it away to needy, never charged people for produce

- home

- home use

- home use

- I give away about $1 / 2$ of what we produce and or can or dry etc

- I sell from my home and make some deliveries.

- I trade or give away surplus to neighbors without

- individuals

- individuals

- individuals

- internet sales

- just for self usage

- lanco

- local calf pool

- local convience store/grocery

- Local Hub Aggregator

- local produce market

- local word of mouth

- milk company
- MOVGA

- needy

- neighbors

- on farm pickup only with lamb

- onfarm store possibly

- online

- online farmers market

- online farmers market

- online farmers market

- on-line markets

- pick your own

- pick your own

- plant shows

- $\quad$ pre-ordered bulk sales from our farm

- private customers

- private treaty

- $\quad$ private treaty and sales of req angus

- retail outlets such as co-ops, specialty shops

- share with friends

- $\quad$ small sales at small gatherings

- $\quad$ specialty shops for our value added products

- Tamarack, a couple of stores and bed and breakfast

- usually give extra to friends and senior center

- wholesalers

- Wild Ramp - indoor farmers market consignment

- will sell hay by signs/ads

- word of mouth

- word of mouth 
Question 11. How many miles (one-way) is the closest place where you could sell your food products? (ie. Farmers market, food hub, or buyer, etc.)?

All producers were asked to answer this question.

\begin{tabular}{|l|l|r|r|r|r|r|}
\hline Description & DATA CODE & N & MEAN & \multicolumn{1}{|c|}{ STD. } & MEV & MAX \\
\hline Distance to nearest market (miles) & MKTMILES & 539.00 & 13.36 & 12.24 & 0.00 & 100.00 \\
\hline
\end{tabular}

Question 12. Did you sell any of the food products you produced in 2012?

All participants were asked to answer this question. In this table, SUM refers to the total number of observations coded as "1" for each item.

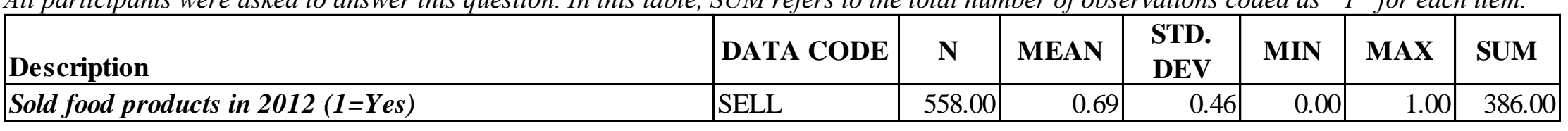


Question 13. "Since you indicated in question 12 that you DID NOT SELL any of the food products you produced in 2012, please tell us whether you agree or disagree with the following reasons for choosing not to sell food products by placing an $\mathrm{X}$ in the appropriate column."

Only participants who indicated that they did not sell food product in 2012 in Question 12 were asked to answer this set of questions. In this table, values in the columns labeled " 1 " to " 5 " represent percentage of respondents, $N$, whose answers corresponded to the following Likert scale.

$1=$ Strongly disagree, $2=$ Disagree, $3=$ Neither agree nor disagree, $4=$ Agree, and 5=Strongly Agree. NA refers the percentage of respondents who skipped or did not indicate an answer for the given statement.

\begin{tabular}{|c|c|c|c|c|c|c|c|c|c|c|c|c|c|}
\hline Description & DATA CODE & $\mathbf{N}$ & MEAN & $\begin{array}{l}\text { STD. } \\
\text { DEV }\end{array}$ & MIN & MAX & SUM & 1 & 2 & 3 & 4 & 5 & NA \\
\hline I'm not interested in selling the food I raise - it's just a hobby. & NSHOBBY & 175 & 3.34 & 1.06 & 1 & 5 & 584 & $5 \%$ & $17 \%$ & $33 \%$ & $31 \%$ & $14 \%$ & $2 \%$ \\
\hline Too far to travel to sell at a profitable marketing outlet & NSMKTFAR & 174 & 2.75 & 1.07 & 1 & 5 & 479 & $12 \%$ & $30 \%$ & $34 \%$ & $18 \%$ & $6 \%$ & $2 \%$ \\
\hline Don't have time to sell foods I grow/raise. & NSTIME & 163 & 3.25 & 1.03 & 1 & 5 & 530 & $5 \%$ & $19 \%$ & $32 \%$ & $34 \%$ & $10 \%$ & $3 \%$ \\
\hline Difficulty hiring the type of labor I need. & NSLABOR & 171 & 3.02 & 1.00 & 1 & 5 & 516 & $8 \%$ & $17 \%$ & $47 \%$ & $21 \%$ & $7 \%$ & $2 \%$ \\
\hline Would not be profitable to sell the foods I produce. & NSNPROFIT & 170 & 3.06 & 1.07 & 1 & 5 & 521 & $8 \%$ & $22 \%$ & $36 \%$ & $25 \%$ & $9 \%$ & $2 \%$ \\
\hline Don't think there is enough demand in local markets. & NSDEMAND & 173 & 2.65 & 0.97 & 1 & 5 & 458 & $9 \%$ & $40 \%$ & $29 \%$ & $18 \%$ & $3 \%$ & $2 \%$ \\
\hline Pest/disease problems limit my ability to sell my products. & NSPEST & 169 & 2.80 & 1.01 & 1 & 5 & 474 & $7 \%$ & $34 \%$ & $37 \%$ & $15 \%$ & $7 \%$ & $2 \%$ \\
\hline $\begin{array}{l}\text { Complicated regulations make it difficult to sell the food I } \\
\text { produce. }\end{array}$ & NSREG & 171 & 3.14 & 1.04 & 1 & 5 & 537 & $4 \%$ & $25 \%$ & $39 \%$ & $21 \%$ & $12 \%$ & $2 \%$ \\
\hline $\begin{array}{l}\text { I'm afraid of the consequences if the food I produce makes } \\
\text { someone sick. }\end{array}$ & NSFSAFETY & 170 & 2.88 & 1.06 & 1 & 5 & 489 & $9 \%$ & $28 \%$ & $34 \%$ & $22 \%$ & $6 \%$ & $2 \%$ \\
\hline I'd rather give away my extra produce than sell it. & NSGIVEWAY & 183 & 3.67 & 1.04 & 1 & 5 & 672 & $4 \%$ & $9 \%$ & $25 \%$ & $39 \%$ & $22 \%$ & $2 \%$ \\
\hline I used to sell but am now retired. & NSRETIRE & 160 & 2.74 & 1.12 & 1 & 5 & 438 & $16 \%$ & $24 \%$ & $41 \%$ & $11 \%$ & $9 \%$ & $3 \%$ \\
\hline
\end{tabular}

\section{Question 14. Is there any other reason why you decided not to sell the food you produced in 2012?}

Only participants who indicated that they did not sell food product in 2012 in Question 12 were asked to answer this question. Responses are listed here. $N=109$

- if I can afford to give it away, I would rather do that than charge people for it. I feel blessed to have grown it.

- at the local farmers market a certain fee/week or per season was required. If I have an extra 1/2\# asparagus, marketing it would cost me money, so I'd rather give it away

- bear have ruined crop for third year in a row.

- cant handle large garden too busy have small garden

- Cost of garden seed is too expensive to produce more than family needs

- did not have enough

- Did not produce enough to sell.

- Didn't grow enough quantity. 
- didn't have any

- didn't have enough

- didn't raise enough

- didn't raise that much to sell any

- disorganized year, bad weather, did not produce enough to sell

- don't raise my garden to sell. I raise it for us.

- don't want to mess with the bureau regulations or liability.

- for home use

- garden produce for selves and to give away

- getting started

- give to family

- grew what was necessary and easy to handle as a hobby

- home use only

- I am 80 years old and retired

- I can all that I produce for my family

- I can and use all I raise

- I chose to give the extra away to people who could use it (extended family)

- I didn't have enough land to produce a large volume of food. But I am working on that little at a time, making sure the small parcels of land $\mathrm{i}$ acquire I can buy free of any mortgages.

- I do not sell to public for food, personal choice

- I ended up giving away (or trading) any excess I could not raise enough to sell but did like to - I need the \$

- I feel God gave me plenty and I like to share what I have with those who don't.

- I give extra food away and supply my grown children

- I grow for own use

- I grow just a little bit to say I have a garden. Not planning to grow to sell.

- I had a knee replacement and was unable to function fully

- I had a very productive flock of sheep and sold all my lambs privately as grassfed custom lamb. It simply became too much work for not enough money. the reason i stopped raising lamb was lack of appropriate land, coyotes, and long distance to markets and especially to processor.

- I have done so in past years but in rural areas it is hard to sell because everybody raises gardens and as stated above most people give away excess produce.

- I have never sold products produced. No one complains about free products. Some products (apples) are not top quality.

- I just produced enough for friends and family.

- I like to help old people that can work anymore

- I only raise garden food and honey for personal and family use 
- I used all of it for summer food and to can for winter

- I work long hours at a hospital that requires mandatory overtime

- id rather give it to someone who needs it

- I'm not good at sales; too much competition; too many farmers markets; lack of funds

- It was the first year I actually had a garden and we consumed most of it at home. Any extra I gave away to friends.

- it's a hobby. Why not give to friends, neighbors, and relatives.

- it's a lot of work; I'm 71 yrs old but still enjoy farming

- its not very profitable in that a lot of buyers are just price haglers who want to make money as middlemen to larger markets - resellers.

- just didn't produce enough to sell

- just providing for a large family.

- $\quad$ kept it for my own personal use and gave it to family members

- moved and didn't have time to do much with the farm

- my wife and I can most of it and give a good bit of the peaches, apples and pears to brothers and sisters and children

- no market; low productivity

- not able to raise a great amount because of age

- not enough

- not enough quantity

- Not enough volume, also quality concerns due to pest pressure.

- Not marketable enough in quality due mostly to BMSB damage. Not enough quantity yet.

- Not worth it.

- not worth the time for the quantity I had

- only raised enough for us

- other obligations

- our age may still sell if have extra

- own use only

- $\quad$ peach trees froze; apples and pears did also

- profitability; can't compete

- raise a small amount. Just for family

- $\quad$ raise enough to supply myself and family members

- raised for family use

- $\quad$ rather see those friends in need have it that for it to go bad

- $\quad$ snow and they don't weigh enough

- the attitude of some people look at what you have. The same way when you give it them like it is no good. I'm retired.

- The deer ate everything I planted so I concentrated on constructing my high tunnel. 
- the garden didn't do wwell because of the weather. What I raised I canned and used myself.

- the government take his part of the money or you have to license to sale

- the markets charge too much money to sell.

- the produce and eggs are for friends and family

- The summer was to hot and dry.

- there is not enough return on investment to be profitable

- this is for personal enjoyment and family food crops. Growing apples as learning experience with espalier.

- time and health

- time and the amount

- Time!

- time/only produce for self

- too busy

- too far to market small amounts

- too old. Thankful we can still raise some for ourselves

- Took an extended vacation

- usually produce enough for family

- very bad season, storms, blight, not a good crop

- Was unable to maintain the garden due to other life events.

- we could can or freeze it for my family's use.

- we do not grow enough garden products to sell. We grow for ourselves because we like our home grown better than commercial but we do not grow enough to have a dependable amount to sell. And we like to give away any extra.

- we live on a rural area and many people still raise their own gardens so there is not the population to support a viable farmers market. We use to participate as vendors but it was discouraging to bring home bushels of unsold produce.

- we mostly produce food products for ourselves and children mostly just give away the extras of course we sell the cattle calves and only keep one or two for beef

- we need a farmers market to be able to sell; I had extra and couldn't get rid of it, so I canned it.

- We only raised for our household last year

- we produce for 3 household

- we raise a small garden for our own use

- we raise food for our own and families use.

- we raise it for our own use; friends and family get any excess (after canning/freezing)

- we sold at farmers market but I had problems with the senior checks; didn't know needed to take class to be able to accept them

- we use all food raised here for ourselves

- we use it all for our family.

- we use most for personal need 
- we use the food we produce for our family and friends. I give it away.

- we used all I grew for my family.

- we usually raise enough for us and our family

- working at a fulltime position which did not allow time for extra food production

- disagreed with management of local farmers market

Question 15: "Which reason best describes why you sell the food you raise? (Please check only one.)"

Only participants who answered "YES" to question 10, indicating that they sold food products in 2012, were asked to answer this question.

\begin{tabular}{|l|l|r|r|r|r|r|}
\hline Description & DATA CODE & MEAN & $\begin{array}{l}\text { STD. } \\
\text { DEV }\end{array}$ & MIN & MAX & SUM \\
\hline I produce more than I can eat, so I might as well sell the extra. & SEXTRA & 0.18 & 0.39 & 0 & 1 & 68 \\
\hline I sell my food products to earn income. & SINCOME & 0.51 & 0.50 & 0 & 1 & 192 \\
\hline $\begin{array}{l}\text { I enjoy the social connections I get when selling the food } \\
\text { products I produce. }\end{array}$ & SSOCIAL & 0.16 & 0.36 & 0 & 1 & 58 \\
\hline Other & SOTHER & 0.05 & 0.22 & 0 & 1 & 19 \\
\hline
\end{tabular}

Responses to "Other" and Comments, Question 15: $N=24$

- all of the above

- all of the above

- business

- EATING LOCAL IS IMPORTANT

- for canning at home

- give away some to friends and neighbors

- give options

- give rest away

- I enjoy selling fresh veggies and fruits and flowers to local people - I enjoy helping people

- I sell goat milk soap to help pay for the feed. The same with eggs

- I want my farm to be sustainable so I feel it needs to earn a profit.

- I want to make healthy food available to more people but I can't afford to give it away because then I have to work off the farm more

- income, however, locally grown natural products provide a much needed service

- Never waste food! Any unsold is brought back and processed for storage

- providing local grown for below grocery store price to locals

- rather give away

- sold beef cattle to buyer for feed lots 
- Somewhere between all of the above.

- Sustains my family while providing a service I care deeply about

- The reasons above are about equal for me.

- to earn income, social connections, provide healthy local food choices to our "neighbors"

- to pay for farm expense provide quality food for others

- To promote healthy products for ourselves and the public

Question 16: "What percent of your farm income in 2012 was from sales through the following marketing outlets? (Note: They should add up to 100.)"

Only participants who answered "YES" to question 10, indicating that they sold food products in 2012, were asked to answer this question. $N=409$

\begin{tabular}{|l|l|r|r|r|r|}
\hline Description & DATA CODE & MEAN & $\begin{array}{c}\text { STD. } \\
\text { DEV }\end{array}$ & MIN & MAX \\
\hline Farmers Markets & SFM & 33.59 & 40.02 & 0 & 100 \\
\hline Community Supported Agriculture (CSA) & SCSA & 4.33 & 16.74 & 0 & 100 \\
\hline Restaurants & SREST & 3.25 & 13.95 & 0 & 100 \\
\hline Grocery Stores & SGROC & 2.01 & 10.63 & 0 & 98 \\
\hline Schools & SSCHOOL & 0.93 & 4.41 & 0 & 45 \\
\hline Hospitals & SHOSP & 0.01 & 0.16 & 0 & 2 \\
\hline Roadside Stands & SRS & 7.92 & 21.22 & 0 & 100 \\
\hline Processor/Finisher & SPROCFIN & 5.12 & 18.93 & 0 & 100 \\
\hline Vegetable Auctions & SVEGAUC & 1.20 & 7.49 & 0 & 85 \\
\hline Stockyard/buyer & SSY & 16.75 & 34.15 & 0 & 100 \\
\hline Other & SOTH & 10.52 & 25.68 & 0 & 100 \\
\hline
\end{tabular}

Responses to "Other" and Comments, Question 16. $N=89$

- $4 \mathrm{~h}$ fund raisers

- agritourism

- bulletin board advertisment

- classes and workshops

- cost-share for individual buyers for hogs

- county calf pool

- co-workers, friends, neighbors
- coworkers, neighbors

- customers at farm

- dairy farm

- neighbors

- Direct Farm Sales

- direct sales from farm

- direct sales to individuals 
- direct to friends, acquaintances

- door to door neighbors

- $\quad$ error- we have drive-in customers for eggs, summer produce

- ethnic buyers

- ethnic market

- Family and Friends

- FAMILY, friends

- feed calves for fair

- feed store

- friends

- friends

- friends and family

- friends and family members

- friends and neighbors

- friends and neighbors

- friends and neighbors

- from farm

- from home and deliver

- Gavilon Grain

- gift/tourist shops

- give away

- gov subsidy nrcs

- Hay to local farmers

- home

- I sell bread and biscotti to retail stores.

- I sell from my home. Sometimes I deliver to customers.

- individual buyers

- individuals

- individuals

- Individuals

- Individuals

- individuals at farm

- indivudals

- Internet
- $\quad$ korean friends; church member

- Lease of land

- local people

- local produce market

- mail

- neighbors

- Neighbors and Church Family

- On farm sales

- on farm sales of beef cattle, frozen meat and vegetables

- on my farm

- On sight

- online Monroe Farmers Market

- other farmers

- overseas market; some NY

- people i know

- people who buy directly from us

- people without a garden

- people would just call and come to my home

- person

- person to person

- Person to person(at swaps and delivery!)

- pick your own

- pre-ordered bulk sales from the farm

- private fam buyers

- $\quad$ private sale to individuals

- private treaty

- put 1 but was only one marked so changed to 100

- put 90 - what about other 10 ?

- pyo

- referals

- rentals

- $\quad$ selling directly to friends and neighbors

- senior voltures

- $\quad$ some farmers Market 
- Special order to individuals

- $\quad$ specialty shops

- Wholesale
- Wild Ramp

- WORD OF MOUTH

Question 17. "Which broad category best represents the gross sales from your farm in 2012?"

Only participants who answered "YES" to question 10, indicating that they sold food products in 2012, were asked to answer this question. $N=378$

\begin{tabular}{|l|r|r|r|}
\hline Category & CODE & Number & \% \\
\hline Less than $\$ 1,000$ & 1 & 83 & $22 \%$ \\
\hline$\$ 1,000-\$ 2,499$ & 2 & 76 & $20 \%$ \\
\hline$\$ 2,500-\$ 4,999$ & 3 & 44 & $12 \%$ \\
\hline$\$ 5,000-\$ 9,999$ & 4 & 50 & $13 \%$ \\
\hline$\$ 10,000-\$ 24,999$ & 5 & 53 & $14 \%$ \\
\hline$\$ 25,000-\$ 39,999$ & 6 & 15 & $4 \%$ \\
\hline$\$ 40,000-\$ 49,999$ & 7 & 13 & $3 \%$ \\
\hline$\$ 50,000-\$ 99,999$ & 8 & 24 & $6 \%$ \\
\hline$\$ 100,000-\$ 249,999$ & 9 & 14 & $4 \%$ \\
\hline$\$ 250,000-\$ 499,999$ & 10 & 0 & $0 \%$ \\
\hline$\$ 500,000-\$ 999,999$ & 11 & 2 & $1 \%$ \\
\hline$\$ 1,000,000$ or more & 12 & 4 & $1 \%$ \\
\hline
\end{tabular}


Question 18. "Which broad category best represents the gross sales from your farm in 2014?"

Only participants who answered "YES" to question 10, indicating that they sold food products in 2012, were asked to answer this question. $N=372$

\begin{tabular}{|l|r|r|r|}
\hline Category & CODE & Number & \% \\
\hline Less than $\$ 1,000$ & 1 & 45 & $12 \%$ \\
\hline$\$ 1,000-\$ 2,499$ & 2 & 66 & $18 \%$ \\
\hline$\$ 2,500-\$ 4,999$ & 3 & 46 & $12 \%$ \\
\hline$\$ 5,000-\$ 9,999$ & 4 & 45 & $12 \%$ \\
\hline$\$ 10,000-\$ 24,999$ & 5 & 68 & $18 \%$ \\
\hline$\$ 25,000-\$ 39,999$ & 6 & 28 & $8 \%$ \\
\hline$\$ 40,000-\$ 49,999$ & 7 & 13 & $3 \%$ \\
\hline$\$ 50,000-\$ 99,999$ & 8 & 29 & $8 \%$ \\
\hline$\$ 100,000-\$ 249,999$ & 9 & 17 & $5 \%$ \\
\hline$\$ 250,000-\$ 499,999$ & 10 & 8 & $2 \%$ \\
\hline$\$ 500,000-\$ 999,999$ & 11 & 3 & $1 \%$ \\
\hline$\$ 1,000,000$ or more & 12 & 4 & $1 \%$ \\
\hline
\end{tabular}


Question 19. "Please indicate how much the following factors do or do not limit your ability to expand your farm by placing an $X$ in the appropriate box."

Only participants who indicated that they sold food product in 2012 in Question 12 were asked to answer this question.

\begin{tabular}{|c|c|c|c|c|c|c|c|c|c|c|c|c|c|}
\hline Description & DATA CODE & $\mathbf{N}$ & MEAN & $\begin{array}{l}\text { STD. } \\
\text { DEV }\end{array}$ & MIN & MAX & SUM & 1 & 2 & 3 & 4 & 5 & NA \\
\hline Low prices for product sold & SPRICE & 361 & 2.44 & 1.13 & 1 & 4 & 881 & $35 \%$ & $4 \%$ & $44 \%$ & $17 \%$ & $0 \%$ & $59 \%$ \\
\hline Pest/disease problems & SPEST & 369 & 2.51 & 1.07 & 1 & 4 & 928 & $30 \%$ & $4 \%$ & $52 \%$ & $15 \%$ & $0 \%$ & $56 \%$ \\
\hline \begin{tabular}{|l|} 
Not enough water \\
\end{tabular} & SWATER & 356 & 1.87 & 1.11 & 1 & 4 & 664 & $60 \%$ & $3 \%$ & $28 \%$ & $9 \%$ & $0 \%$ & $61 \%$ \\
\hline Not enough land & SLAND & 366 & 1.87 & 1.18 & 1 & 4 & 683 & $63 \%$ & $2 \%$ & $21 \%$ & $14 \%$ & $0 \%$ & $57 \%$ \\
\hline Limited access to large-scale equipment & SEQUIP & 360 & 1.85 & 1.11 & 1 & 4 & 666 & $59 \%$ & $7 \%$ & $23 \%$ & $11 \%$ & $0 \%$ & $59 \%$ \\
\hline Difficulty hiring the type of labor I need & SLABOR & 370 & 2.13 & 1.20 & 1 & 4 & 788 & $49 \%$ & $6 \%$ & $27 \%$ & $18 \%$ & $0 \%$ & $55 \%$ \\
\hline Complicated regulations & SREG & 342 & 2.28 & 1.18 & 1 & 4 & 780 & $41 \%$ & $8 \%$ & $32 \%$ & $18 \%$ & $0 \%$ & $68 \%$ \\
\hline Lack of time to market/distribute my products & STIME & 371 & 2.43 & 1.14 & 1 & 4 & 903 & $35 \%$ & $4 \%$ & $44 \%$ & $18 \%$ & $0 \%$ & $55 \%$ \\
\hline Lack of production related knowledge & SPRODKN & 363 & 1.75 & 1.00 & 1 & 4 & 634 & $62 \%$ & $6 \%$ & $29 \%$ & $4 \%$ & $0 \%$ & $58 \%$ \\
\hline Long travel distance to market & SDISTANCE & 370 & 1.88 & 1.09 & 1 & 4 & 697 & $58 \%$ & $3 \%$ & $32 \%$ & $7 \%$ & $0 \%$ & $55 \%$ \\
\hline Lack of demand in market for my products & SDEMAND & 363 & 1.91 & 1.07 & 1 & 4 & 693 & $56 \%$ & $4 \%$ & $34 \%$ & $6 \%$ & $0 \%$ & $58 \%$ \\
\hline Lack of access to local processing & SPROC & 366 & 1.98 & 1.15 & 1 & 4 & 726 & $53 \%$ & $8 \%$ & $25 \%$ & $13 \%$ & $0 \%$ & $57 \%$ \\
\hline Lack of marketing related knowledge & SMKTKN & 360 & 1.86 & 1.06 & 1 & 4 & 671 & $58 \%$ & $5 \%$ & $32 \%$ & $6 \%$ & $0 \%$ & $59 \%$ \\
\hline Lack of money to invest in expansion & SCAP & 367 & 2.66 & 1.20 & 1 & 4 & 976 & $31 \%$ & $3 \%$ & $37 \%$ & $30 \%$ & $0 \%$ & $56 \%$ \\
\hline High input costs & SINPCOST & 364 & 2.76 & 1.12 & 1 & 4 & 1004 & $25 \%$ & $3 \%$ & $44 \%$ & $28 \%$ & $0 \%$ & $58 \%$ \\
\hline High processing costs & SPROCCOST & 360 & 2.26 & 1.12 & 1 & 4 & 814 & $39 \%$ & $10 \%$ & $37 \%$ & $14 \%$ & $0 \%$ & $59 \%$ \\
\hline
\end{tabular}

Question 20. "Please comment on the greatest limitations you face to producing or marketing the food you produce."

Only participants who indicated that they sold food product in 2012 in Question 12 were asked to answer this question. N=326

- being a teen and trying to balance all my time to get things done

- 1. lack of a market 2. lack of access to capital

- 1.distribution to markets where my specialized organic products could be sold at a profit. 2. hydrofracking operations in our rural agricultural county - this highly toxic industry does not mix at all with small family farms if our well water, surface water or ground is contaminated there goes our farming enterprise and the value of our land. air quality also a great concern (due to the fracking).

- 73 years of age

- a place to market my produce

- A reliable outlet in the county other than the farmers market

- Access to rent or buy additional land

- Access to more quality land, equipment and reliable labor and money to expand 
- adequate rainfall for raising grass-fed beef

- advancing age and declining health

- affordable labor and government regulations

- age

- age

- age

- age

- age and health.

- age and health.

- $\quad$ age and money

- age and physical condition

- age and stamina

- age has lead me to reduce the number of animals I raise

- $\quad$ age is our biggest limitation; used to sell but retired

- age/health

- Aging.

- am trying to invest in water conservation methods for current spring fed tanks to alleviate problems during dry season

- amount of labor required by 1 person

- Amount of space. We live on a mountain top and are working on utilizing the 4 acres we have that are tillable. That is slow because of lack of a tractor.

- availability of water. We installed two cisterns in 2012 to catch and hold 2600 gallons of rain water. It was a dry year and we captured very little. They are now full.

- basically just a hobby for me. I grow in available space for my use and sell the excess

- between drought conditions and the derrecho last year our garden was like an oasis in the desert for deer and other animals. We have fencing up around all of our gardens but it has not been enough

- biggest limitation is financial

- bugs and disease, high fuel prices, cost of doing business is growing faster than we can keep with, scared of this new GAP program

- closest usda inspected slaughterhouse are both 90 miles away

- competition from growers paying a low, low wage - that creates a price problem. I want to be fair to labor, how I need to make it up in price.

- complicated regulations - paperwork/record keeping and 4-6 time a year inspected by WVDA and local health department

- $\operatorname{cost} \$$

- cost of all input items

- Cost of Fuel

- cost of pesticides needed - bad problem potato bugs 
- cost of seeds and nutrients

- cost of supplies

- costs of inputs

- damage by deer, raccoons and groundhogs

- deer and pest, market for my produce

- deer come by dozens to eat before produce is ready to harvest. Don't have a pump in pond for water to use in garden. Have had vandalism the last 2 years which destroys $1 / 2$ or more of our crops.

- deer pressure; lack of competent summer help

- definitely capital, all the regulations and required equipment for documentation and production for a creamery is high. also high liability insurance costs

- depressed prices during peak season. Lack of time to harvest/sell produce

- Developing a local outlet for my produce will be challenging also organic certification costs will also be a factor of whether or not to become "organic" on a small scale operation.

- disability not enough help. Picking beans is a serious back killer.

- disease and pest control particularly with stone fruit and stink bug control; lack of a larger cold storage facility.

- disease, pests, environment, lack of water for irrigation, ...

- distance to customers: customers do want our product but do not have time to travel to farm and we do not have time to travel to them. CSA has established drop off sites but customers still request closer locations or in office dropoffs. We have arranged these as best we have time for them. Interested and reliabler local helpers are in short supply. Must be able to drive to farm to work here.

- don't have any

- due to my age, I can't always get the funding I need to grow.

- due to working an off-farm job I have limited time to expand my direct to consumer sales

- ear corn - market has dwindled due to people wanting shelled corn. Hay - peoples mindset is now to purchase 2nd cutting hay which weakens demand for first. Cattle - sold to individuals and direct to feed lot.

- $\quad$ EPA

- $\quad$ EPA and DEP

- Experience and time, we are moving forward, but relying on patience and experience as we grow and create foundation for that growth. Want customers to have a good experience of us and careful not to overextend ourselves at their expense.

- federal and state regulations. County zoning laws; labor. My age - 59

- feed prices, drought

- Finding a market that I can rely on that can fit into my full time job situation

- Finding buyers for my goods

- finding good local processor

- Finding help

- for the effort not enough income; what we do is (...) 
- gas price

- $\quad$ getting enough help to harvest

- getting old, age

- $\quad$ getting the education and land to produce more

- $\quad$ getting the word out to people we are here and getting a chance to talk about natural growing.

- golf seems to occupy a greater \% of my time

- gout regulations; disease and pest; labor

- goverment regulations

- government regulations

- greatest limitation money for expanding, equipment, well for more irrigation, fruit trees, berry plants etc

- $\quad$ growing good crops

- growing older

- hauling the equipment to put the garden in and time to do it

- have none at this time

- have smaller children so this limits my time for farming/gardening (family obligations) need more land

- having enough ground to produce quantities for sale to produce markets and processors

- having the time and the money to plant, harvest, and sell the produce

- Health issues.

- health problems

- Hi cost of production and the timing of crop readiness to meet market demands.

- $\quad$ high cost of equipment and taxes. Cost of gas to go to market.

- high cost of feed, care and equipment for the poultry lack of level farmland for gardening. Cost of final product seem to always be higher than what the local store is getting for their product would like to own a profitable farm type business but don't know how i would ever afford a farm or get financing for one - even a small one.

- high cost of fertilizer and lime.

- High costs associated with producing feed for my cattle.

- high feed cost

- high feed cost

- high input costs and low retail value

- $\quad$ hiring help to harvest is my bottleneck. I can sell all that I raise. Teens will not work in the hot weather and they want $\$ 10 /$ hr and do \$5/work.

- I a personally limited mostly by lack of land; and while there are folks who let me produce on their property, my time is also a limiting factor so driving back and forth is a problem. Additionally, there are opportunities for producing value-added products but lack of a certified kitchen and prohibitively difficult health dept. regulations are both hurdles in my area.

- I am 75 years old 
- I am a lone farmer. What I do, I do by myself. Care for the animals, bottle feed, feed, garden, make soap, wool ornaments, wool covered soap bars, baskets, collect eggs and collect wild herbs, etc.

- I am limited on time because of family activities; we have five children at home. Health andfinances sometimes limit my scheduled improvements.

- I am only one person and I am not interested in hiring someone. I also live in an area of low population density and low incomes.

- I do not have the education to do the marketing and the business part of it very well. I wish I had went to school for agriculture.

- I do not have the extra land, money, time nor physical ability to grow extra for marketing. I would like to do so in the future though.

- I don't grow to sell. I garden for our own use. I am too busy with my bakery business to garden for income. There are actually good garden plots available in town for $\$ 1 /$ year if I wanted to expand production. It is a little tempting.

- Divorced now and had to sell tractor but can't afford one. I need an irrigation system for garden and berries, I collect rain water but have to carry it.

- I have no desire to expand as I only want to raise for my family.

- I have no limitations

- I have no problem marketing my produce

- I market heritage turkeys so finding a market and providing refrigeration is the worst problem

- I need better equipment.

- I need labor/help terribly!! For certain seasons

- I think a lot of marketing strategies only make sense once you cross a certain scale threshhold - it doesn't make sense to sit at farmers market all day for under $\$ 100$. but with a perishable product and no access to cold storage, it can be discouraging to not find a market when you need it. my ideal would be to participate in a larger CSA as a producer member. I could continue to try to grow as much diversity as possible at all times, and just drop off what I harvest each week. That would give me the flexibility to expand slowly and be able to cut back on hours at my off-farm job a little each year.

- I work a full time job so lack of time is the biggest problem. Then getting help to harvest when I am used to being able to do an acre at a time.

- I would have to say that the weather.

- I would like to make grape juice to sell directly to schools etc. but no one around here seems to know the regulations and of course we are interested in a winery but don't know if we have enough marketing knowledge.

- I would raise broiler chickens but I don't know how to process. I may not even consider if I know how - but couldn't bring myself to butcher!

- I'm getting up in years, my health and age limit me somewhat

- im not limited by anything except age and desire

- in 2012 drought conditions decreased the amount of fruit produced

- investment capital

- Erratic and severe weather has been the biggest problem over the last year. 
- $\quad$ irrigation; regulations related to value added products and no available commercial kitchen; no available aggregation or storage facilities nearby

- Just being over 55 and doing all the work along with my spouse. Even though we use equipment, most of the work is done by hand. We wish we were 30 and starting this.

- just higher cost of fertilizer, fuel, interest on loans, machinery, lack of any more land that could be used in this community. Health problems, lack of interest from other family members because of higher paying factory jobs.

- knowing and growing what the consumer wants.

- labor

- labor at times; water for irrigation.

- labor, equipment, weather

- labor-help needed to do more work

- labor-intensive; getting premium prices for quality

- lack of city water; depend on well for livestock household and gardening.

- Lack of distribution network.

- lack of help and land

- Lack of help plus being not close to center of social strata of area!

- lack of investment income - desires to construct high tunnel

- Lack of irrigation.

- lack of knowledge regarding the efficient methods of raising organic crops. Lack of time and energy to raise, harvest, and market my produce.

- Lack of land and proper equipment. Oh, and money!

- lack of land; lack of competent man power

- lack of market

- lack of money

- lack of money for expansion and repairs; lack of time to do everything done and lack of usable labor

- lack of profit

- lack of time

- lack of time and health limitations

- lack of time due to offsite occupations, working capital

- Lack of TIME!!!! Too much regulation. Customers should be able to choose what they want to buy. They should not be denied access to certain foods (i.e. raw milk) due to over zealous regulation.

- lack of water for irrigation; drought; freezes

- land and money

- laws favor large corporate farming. I believe strongly that the laws in the US are des(...) to stifel small farm operations, specifically in dairy, meat processing, and organic certification. 
- licenses, permits, regulations. Fear of big brother ie government tax expenses access to seeds, fertilizer and equipment.

- limit to irrigation - not enough labor to do everything needed. Need more special equipment which is very expensive.

- limited amount of time; there would have to be a good return to justify the time spent.

- limited finances

- Limited tillable acreage; we concentrate on berries which are labor intensive to pick.

- located in an area where too many love walmart. They feel walmart makes it right there, packages it, sells it, and its cheap! So buy it!

- low demand and low income in the local area

- Low income county so not alot of money for spending on buying fresh products. A lot of people are on food stamps in this county.

- low prices, pests, long travel

- Managing Labor (complying with all the laws, the paperwork, keeping employees working enough for them to stay, etc.)

- marketing

- marketing - im not well-educated in proper marketing - but understand that I have no desire to set at a farmers market. I prefer to sell off the farm website use and design is something I need help with.

- Marketing and advertising

- marketing and processing.

- marketing opportunities, financial backing and land availability

- Marketing, good prices

- Meat processing facility

- money

- money

- Money

- money $\$$

- money and time

- Money for expansion. I have had to expand slowly as I do not like to take out loans to expand.

- Money! I could do much more if I could hire unskilled labor to do the heavy work I cannot do at my age. (60)

- money. Farming return on investment is too low to support conventional borrowing. Off-farm income needed to pay taxes; certain funding programs create artificial low prices and unlevel playing field. We desire to provide honest, healthy, local food but find the size needed to support a family makes capital investment daunting.

- mostly my age; lack of local help young people in area not interested in working ever for decent wage

- mostly time required to harvest and process for market. Due to other endeavors

- my age

- my age can't do as much as I want to

- my farm has poor pasture and acidic soils. It will take time to improve it for livestock and money for fertilizer and lime. Orchard. I have limited places for garden or don't want to put farm from house because deer and toher animals will eat it . As it is, i have a six ft fence around my garden. trouble finding economical source of lime. 
- my gardening operation is very small. If I can market my produce in the most simply manner (roadside, on farm) this is about the only way I can operate. I am a full time truck driver.

- my greatest is the lack of time I am 80 yrs old and I don't want to expand. I want to go the other way.

- my greatest limitation is time. I work full-time off-farm and there just aren't enough hours to accomplish everything

- my location (mountain top) gets snow when lower levels don't and limit early dates of planting. My physical slowdown limits me a small amount (I'm 84 yrs old).

- my physical ability to do the work I need to do at times

- my primary product is honey. My greatest limitations are due to winter losses, cost of replacement bees.

- my time and investment cash

- $\quad$ need more viable land and paid off

- no enough demand for what I raise

- not a large enough customer base; and surrounding markets are about the same. Expanding costs a lot of money; for berry plants or fruit frees and especially things like high tunnels or fencing. Would like to see the ability to offer more processed foods; like pickles and relish; and what it would require to have a certified kitchen.

- not enough capital to start off with sufficient product, ie. Seed fertilizer, sacks

- Not enough hours in day/week/months of growing seasons!

- not enough neighbors to pass goods off too!

- $\quad$ not enough places to sell in my county. Farmers market is only open on days I work. I work 10.5 hour days - 4 day 2 /wk and drive 1 hr each way to work.

- not enough time

- not enough time

- not enough time - I work full-time off the farm

- not enough time to produce everything and take it to market after harvest while working a job off-farm

- not enough time to spend on farm-related activities

- not enough usda processing facilities within 50 miles of me - to be able to have competitive rates passed on to me and my customers.

- not feeling well enough and having the ambition to work $100 \mathrm{hr} /$ week

- not having a garden tractor keeps us from doing more

- not having help with the garden is limiting to me. I don't make enough money at it to suport paying someone either.

- not payed enough

- old age

- old age

- $\quad$ old age, handicapped, and cannot get anyone to help

- onerous regulations and limited off-farm slaughter arrangements

- only 24 hours in a day

- operate a beef cattle grain hay farm. I have limited time expand the overall operation. I'm a retired type farmer. 
- organic pest control lack of support from our local ascs office for small opperations

- Organizing my scattered thought process to maximize the limited time I have seems to be my greatest obstacle!

- other commitments that I which limit the amount of time I can dedicate to the farm.

- our location is a challenge for large number of our ethnc buyers

- people with backyard gardens and $4 \mathrm{~h}$ groups selling at farm markets - which many (usually almost all) have existing income. Production costs, mainly gas and fertilzer

- perishability, my own unwillingness to travel to urban markets

- Pest and disease control costs are higher for small operations because of the number of products needed and the cost of the small amounts needed.

- physical disability and no young labor that will work

- predators

- price of feed for cattle and other animals. We had a small flock of laying hens but feed was so expensive there was no profit in it.

- price of materials

- processing costs are huge! Whether that be cattle or gourmet central. That forces many people to go out of state for processing. Other road stands selling non-WV grown produce in my area is hurting the local small farmers too. Argh. Federal regulations are awful too.

- $\quad$ prodicting demand for particular items

- production regulations related to chesapeake bay watershed

- prohibitively high start up costs combined with the inherently uncertain nature of farming make farming as a sole income too risky. Farming part time while working another job is not worth the effort - it just takes away from remaining family time and fixed costs are too high with very small scale farming.

- Proposed local regulations. require individual business license and city B\&O tax.

- quantity of production

- recruiting good laborers to harvest food produced

- regulations

- Regulations

- Resources such as family land available for me to farm as well as money to expand, loans are nearly impossible as well as regulations.

- retired - do not wish to expand or be tied down too much to the farm

- Right now, only my husband \& I run the farm. We both work long hour day jobs. We have 2 very-part-time employees. TIME is \# 1. Regulations are \# 2. Ex: we want to sell our eggs at local convenience stores, but store owners consistently tell us it is illegal [either WVDA or local Health Dept regs]. We cannot convince them otherwise, even sharing regs $\mathrm{c}$ them.

- $\quad$ shelf life and handling of my products are an issue when the weather warms up

- size and local markets

- $\quad$ sometimes we have a drought although I plant in a valley bottom ground. I irrigate my mums (flowers) only. When watering with sprinklers it seems like it takes so much time to get the soil watered. It seems to evarporate in the air. But it helps a little bit enough to keep us going. Also animal predators deer and groundhogs 
- $\quad$ spring workload in greenhouses limit time to put into planting garden to my expectations

- $\quad$ starting income

- $\quad$ still must work to retirement and leaves limited time for farm

- the amount of land and equipment

- The change in our weather patterns. The lack of water. If it does not rain, the ponds do not fill up for us to irrigate out of.

- The demographics and geographics of our area. A sparse, lower income population that is distrubuted over a wide area.

- The distance to larger markets resulting in less capitol to expand...

- the government and political unfairness. Bias hogs

- the government telling me what i can do or not do i cannot sell raw milk or cheese thes hurts my farm a lot!!!!!!!!!!!

- The greataest limitation to producing more food is that local folks will not buy it. I have not been able to encourage many locals to shop at the farmers' market over the past 3 yrs that I have set up at the market. Everyone drives past and waves, but they do not stop or shop. We market and sell our products in Charleston, WV-- a more urban, more populated place.

- the greatest limitation I face is lack of time. Having another job to supplement the farm takes a lot of time away from doing the work you need to do. Especially when its time to make hay.

- The greatest limitations I face as a farmer to produce more food is money for input and growth of my farm and lack of consumers in my area.

- the high price of fuel has caused all things to be out of sight. The cost of feed is outrageous.

- the irrigation

- The main issue would be the seed and fertilizer costs are to high.

- The margin between cost of growing/processing food and low price public is willing to pay is very small

- The over cost and time that it takes to get product to market.

- the price has risen on everything and the price we get for cattle is low.

- the time I have to spend on raising crops. I have other commitments and interests that require my time

- the transaction costs are too high. It costs me the same or less to sell a timber load as it does to sell a single(). Plus most farmers markets are at times you can't have an off-farm job. I cannot sell a sufficient quantity consistently to warrant direct sales.

- The weather is the greatest limiting factor I face producing the food. Late freezes can give me loss on farm income. Too little rain or irregular rain can reduce production. Too much rain can increase disease problems.

- the whitetail deer is the greatest limitation I face because the damage is proportionate to the scale. Exclusion is not viable on 100 acres, termination ma be the onl way. Lets put a bouty out and/or year-round season for the vermin. The distance to a produce growing supply has become cumbersome of late.

- Ther is often a limited market in the state of WV for seedstock that would normally bring a much higher price in another state. Yes, the price received is somewhat higher but not compared to price from other states

- this years weather

- time

- time 
time

- Time

- Time

- Time \& Money

- time, labor

- Time and adequate land

- TIME AND CAPITAL

- time and energy constraints

- time and energy to do the things that need to be done

- time and equipment

- Time and equipment.

- $\quad$ time and money

- Time and money

- Time and weather

- Time constraints

- time enough to do it right and take it to market without hired help

- time outside of off farm job

- time required to produce - my primary product is bread and not able to make enough money for the time it requires.

- Time spent on off farm jobs.

- time to do the gardening.

- time to pay off investments; at 65 years of age is a big factor

- TIME TO WORK THE FARM

- Time. I currently work full time and am in school trying to finish my bachelors degree. My spouse also works full time which means that our days are reallly full and sometimes the farm gets put on hold.

- Tine

- too much rain

- transportation costs - 23 miles away at $10 \mathrm{mpg}=5$ gal fuel per one round trip apprx 20 dollar in fuel+ 10 to see equals $30 \$$ per day tailgating. Before anything sells if I sell 60 to 75 dollars of produce I probably just broke even. I would need to sell approx. 175 to 200 per day to realize any money for 1 day picking and one day selling. i could produce more cattle but the money to start buying cows is not there now. by the time $\mathrm{i}$ got fence and pasture to date no money to buy cows.

- trying to sell what is produced. Trying to produce what will sell.

- uncertain about weather conditions locally. We experienced extreme drought condition in 2012. protecting crops from deer, rabbits, insects, all contribute to us producing less acreage.

- $\quad$ uncertainty about government regulations which may evolve. 
- Understanding how to make all of the little operations into a full time income. How do we grow from our size to a family income of around $\$ 24,000$. That is a low standard and it HAS to be possible.

- Very high cost of utilities.gas,electric.

- very time consuming to deliver or go to farmers markets

- we are getting old and can't do the work that we used to do.

- We do not own the land we work which makes it very difficult to add permanent structures or fully invest our money into improving the land because we never know when we may find land of our own or have to move.

- we have always gave food away so it would be hard to sell it.

- we have bacteria leaf spot deer groundhogs, crows coons moles

- we have no processing center in our county. I also lack the financial resources to invest in equipment such as high tunnel or greenhouses or other equipment that would make it easier to produce more.

- we have no processing places. We would have to travel and it would not be worth the expense

- we need more land

- weather

- weather

- weather

- weather and distance. Approaching mid 70s so health plays a part

- Weather issues for instance, hailstorms. Brown Marmorated Stink Bug is greatly interfering with our IPM program. The only pesticides that can battle the stink bugs interfere with our beneficial insect levels. A mating disruption program is greatly needed for these pests. Fire blight is another issue that wipes out many of our acres of fruit trees each year. Constant maintenance by cutting down trees and burning it out...and spraying pesticides to reduce spores from spreading is costly and not $100 \%$ effective. Other great costs to our business are Workman's Comp Insurance costs, labor issues, and fuel costs.

- weather related problems

- weather, bad to flood

- Weather, insects and disease, government reguations

- weather, lack of available labor, high input costs

- WEATHER,PESTS

- we're in cooler climate so cannot plant real early. Then kids are back in school when season peaks for vegetables. We are very busy with the dairy and all crops involved so are very limited on time. Can't really pay someone to help so we try to do it all. and there just isn't enough time in the day.

- when my produce is ready to sell everyone else's crops are coming in at the same time. Extremely hard to sell, many folks let food waste if I pick it and give it to them. People are getting extremely lazy in these days. Few people are canning. They would rather buy stuff fully processed and i can't do that.

- when you work full time its hard to find time to get done what you need too 
- where I live. not enough population to support expansion. other markets too far away, 100 miles, and do not accept farmers from another state ( next state is 20 miles away)

- while it is necessary to have a full-time job in addition to my farming venture, time and timing is a huge problem. Farmers markets, businesses (deliveries and office contacts for marketing) make it difficult to participate and market due to working full-time and in a dayshift position.

- $\quad$ wildlife-deer, turkey, bear, coyotes, crows

- with berries they must be shipped the same day as they are picked

- with the lack of land and land that can be rented to bring this land to a higher production level the cost of lime and fertlizer to do this makes it not profitable to do so

- working families in my area find it cheaper to buy fast food, than fresh food, poor eating choices. Lack of health education to customers about you are what you eat. Of course their health sucks. Need to be closer to urban areas where people invest in quality food.

- working full time.

- WV milk regulations; deer (pests!)

- WVDA regulations limit us to 1000 broilers/year. Not much motivation when we profit $\$ 3.00 /$ bird. Max we can hope for is only $\$ 3000 / y r$ profit. 
Question 21. "Where is your garden or farm located?"

All participants were asked to answer this question. The following results are presented by state and county. $N=553$

\begin{tabular}{|c|c|c|c|c|c|c|c|c|}
\hline \multicolumn{6}{|c|}{ WV } & \multicolumn{3}{|c|}{ PA } \\
\hline & $\#$ & $\%$ & & $\#$ & $\%$ & & $\#$ & $\%$ \\
\hline Total & 535 & $96.75 \%$ & & & & Total & 6 & $1.08 \%$ \\
\hline Barbour & 20 & $3.62 \%$ & Mercer & 21 & $3.80 \%$ & Washington & 2 & $0.36 \%$ \\
\hline Berkeley & 6 & $1.08 \%$ & Mineral & 19 & $3.44 \%$ & Greene & 1 & $0.18 \%$ \\
\hline Boone & 0 & $0.00 \%$ & Mingo & 0 & $0.00 \%$ & Fayette & 1 & $0.18 \%$ \\
\hline Braxton & 12 & $2.17 \%$ & Monongalia & 3 & $0.54 \%$ & Franklin & 0 & $0.00 \%$ \\
\hline Brooke & 0 & $0.00 \%$ & Monroe & 11 & $1.99 \%$ & Allegheny & 1 & $0.18 \%$ \\
\hline Cabell & 10 & $1.81 \%$ & Morgan & 6 & $1.08 \%$ & Beaver & 0 & $0.00 \%$ \\
\hline Calhoun & 9 & $1.63 \%$ & Nicholas & 20 & $3.62 \%$ & Fulton & 1 & $0.18 \%$ \\
\hline Clay & 11 & $1.99 \%$ & Ohio & 1 & $0.18 \%$ & Montgomery & 0 & $0.00 \%$ \\
\hline Doddridge & 2 & $0.36 \%$ & Pendleton & 0 & $0.00 \%$ & & & \\
\hline Fayette & 27 & $4.88 \%$ & Pleasants & 5 & $0.90 \%$ & \multicolumn{3}{|c|}{ MD } \\
\hline Gilmer & 8 & $1.45 \%$ & Pocahontas & 32 & $5.79 \%$ & & $\#$ & $\%$ \\
\hline Grant & 1 & $0.18 \%$ & Preston & 68 & $12.30 \%$ & Total & 2 & $0.36 \%$ \\
\hline Greenbrier & 7 & $1.27 \%$ & Putnam & 0 & $0.00 \%$ & Garrett & 1 & $0.18 \%$ \\
\hline Hampshire & 71 & $12.84 \%$ & Raleigh & 0 & $0.00 \%$ & Allegany & 1 & $0.18 \%$ \\
\hline Hancock & 1 & $0.18 \%$ & Randolph & 4 & $0.72 \%$ & & & \\
\hline Hardy & 4 & $0.72 \%$ & Ritchie & 9 & $1.63 \%$ & \multicolumn{3}{|c|}{$\mathrm{OH}$} \\
\hline Harrison & 7 & $1.27 \%$ & Roane & 17 & $3.07 \%$ & & $\#$ & $\%$ \\
\hline Jackson & 6 & $1.08 \%$ & Summers & & $0.00 \%$ & Total & 9 & $1.30 \%$ \\
\hline Jefferson & 13 & $2.35 \%$ & Taylor & 7 & $1.27 \%$ & Lawrence & 2 & $0.36 \%$ \\
\hline Kanawha & 5 & $0.90 \%$ & Tucker & 8 & $1.45 \%$ & Gallia & 2 & $0.37 \%$ \\
\hline \begin{tabular}{|l|} 
Lewis \\
\end{tabular} & 13 & $2.35 \%$ & Tyler & 7 & $1.27 \%$ & Belmont & 2 & $0.37 \%$ \\
\hline Lincoln & 4 & $0.72 \%$ & Upshur & 13 & $2.35 \%$ & Harrison & 1 & $0.19 \%$ \\
\hline \begin{tabular}{|l|} 
Logan \\
\end{tabular} & 0 & $0.00 \%$ & Wayne & 1 & $0.18 \%$ & & & \\
\hline Marion & 8 & $1.45 \%$ & Webster & 13 & $2.35 \%$ & \multicolumn{3}{|c|}{ VA } \\
\hline Marshall & 0 & $0.00 \%$ & Wetzel & 0 & $0.00 \%$ & & $\#$ & $\%$ \\
\hline Mason & 7 & $1.27 \%$ & Wirt & 18 & $3.25 \%$ & Total & 1 & $0.18 \%$ \\
\hline Mcdowell & 0 & $0.00 \%$ & Wood & 0 & $0.00 \%$ & Facquier & 1 & $0.18 \%$ \\
\hline & & & Wyoming & 0 & $0.00 \%$ & & & \\
\hline
\end{tabular}


Question 22. "Do you own and/or rent the land where you farm/garden?"

All participants were asked to answer this question. $N=553$

\begin{tabular}{|l|l|r|r|r|r|r|}
\hline Description & DATA CODE & MEAN & $\begin{array}{l}\text { STD. } \\
\text { DEV }\end{array}$ & MIN & MAX & SUM \\
\hline Own a part/rent a part of the land I garden/farm & OWNRENT & 0.16 & 0.37 & 0 & 1 & 90 \\
\hline I own all of the land I garden/farm & OWN & 0.80 & 0.40 & 0 & 1 & 444 \\
\hline I rent all of the land I garden/farm & RENT & 0.04 & 0.19 & 0 & 1 & 20 \\
\hline
\end{tabular}

Question 23. "Since you indicated in question 22 that you own land where you garden or farm, how many generations has it been in your family? ("If you are the first generation please put 1)."

All participants were asked to answer this question.

\begin{tabular}{|c|c|c|c|c|c|c|}
\hline Description & DATA CODE & $\mathbf{N}$ & MEAN & $\begin{array}{l}\text { STD. } \\
\text { DEV }\end{array}$ & MIN & MAX \\
\hline Number generations land has been in family & GENTION & 526 & 2.01 & 1.36 & 0 & 9 \\
\hline
\end{tabular}

Question 24. "How many acres of usable agricultural land do you have access to?"

All participants were asked to answer this question. SUM in this table indicates the aggregate total of acres among all survey respondents.

\begin{tabular}{|l|l|r|r|r|r|r|r|}
\hline Description & DATA CODE & N & MEAN & $\begin{array}{l}\text { STD. } \\
\text { DEV }\end{array}$ & MIN & MAX & SUM \\
\hline Number of acres of agricultural land available to operator & AGLAND & 537 & 93.48 & 211.78 & 0 & 2000 & 50198 \\
\hline
\end{tabular}

Question 25. "How long have you been gardening or farming at your current location?" All participants were asked to answer this question.

\begin{tabular}{|l|l|r|r|r|r|r|}
\hline Description & DATA CODE & N & MEAN & $\begin{array}{l}\text { STD. } \\
\text { DEV }\end{array}$ & MIN & MAX \\
\hline Number years farming at current location & CURLOC & 550 & 25.14 & 18.49 & 1 & 100 \\
\hline
\end{tabular}

Question 26. "How many years of experience do you have farming or gardening?" All participants were asked to answer this question.

\begin{tabular}{|l|l|r|r|r|r|r|}
\hline Description & DATA CODE & N & MEAN & \multicolumn{1}{|c|}{$\begin{array}{l}\text { DTD. } \\
\text { DEV }\end{array}$} & MIN & MAX \\
\hline Number years experience farming/gardening & YEAREXP & 549 & 37.64 & 19.11 & 1 & 90 \\
\hline
\end{tabular}


Question 27. "How many other people work on your farm or garden?"

All participants were asked to answer this question. SUM in this table indicates the total number of people working on the farms sampled.

\begin{tabular}{|c|c|c|c|c|c|c|c|}
\hline Description & DATA CODE & $\mathbf{N}$ & MEAN & $\begin{array}{l}\text { STD. } \\
\text { DEV }\end{array}$ & MIN & MAX & SUM \\
\hline Number people working on farm/garden & PEOPLE & 542 & 2.03 & 6.59 & 0 & 150 & 1099 \\
\hline
\end{tabular}

Question 28. "What is your age?"

All participants were asked to answer this question.

\begin{tabular}{|c|c|c|c|c|c|c|}
\hline Description & DATA CODE & $\mathbf{N}$ & MEAN & $\begin{array}{l}\text { STD. } \\
\text { DEV }\end{array}$ & MIN & MAX \\
\hline Age & AGE & 550 & 58.10 & 13.80 & 15 & 91 \\
\hline
\end{tabular}

Question 29. "What is your gender?"

All participants were asked to answer this question.

\begin{tabular}{|l|l|r|r|r|r|r|}
\hline Description & DATA CODE & N & MEAN & \multicolumn{1}{|c|}{$\begin{array}{l}\text { STD. } \\
\text { DEV }\end{array}$} & MIN & MAX \\
\hline Gender (female $=1)$ & GEN & 550 & 0.34 & 0.47 & 0 & 1 \\
\hline
\end{tabular}

Question 30. "Are you employed off or away from the farm?”

All participants were asked to answer this question. $N=540$

\begin{tabular}{|l|l|r|r|r|r|r|}
\hline Des cription & DATA CODE & MEAN & $\begin{array}{c}\text { STD. } \\
\text { DEV }\end{array}$ & MIN & MAX & SUM \\
\hline Work part-time off the farm & PTIME & 0.18 & 0.38 & 0 & 1 & 97 \\
\hline Work full time off the farm & FULLTIME & 0.35 & 0.48 & 0 & 1 & 190 \\
\hline Do not work off the farm & NOOFWORK & 0.60 & 0.49 & 0 & 1 & 324 \\
\hline
\end{tabular}


Question 31. "Which broad category BEST describes your total household income level in 2012?"

All participants were asked to answer this question. $N=511$

\begin{tabular}{|l|r|r|r|}
\hline Category & CODE & Number & \multicolumn{1}{c|}{$\%$} \\
\hline less than $\$ 10,000$ & 1 & 30 & $6 \%$ \\
\hline$\$ 10,000-\$ 14,999$ & 2 & 19 & $4 \%$ \\
\hline$\$ 15,000-\$ 19,999$ & 3 & 24 & $5 \%$ \\
\hline$\$ 20,000-\$ 24,999$ & 4 & 39 & $8 \%$ \\
\hline$\$ 25,000-\$ 29,999$ & 5 & 34 & $7 \%$ \\
\hline$\$ 30,000-\$ 34,999$ & 6 & 45 & $9 \%$ \\
\hline$\$ 35,000-\$ 39,999$ & 7 & 40 & $8 \%$ \\
\hline$\$ 40,000-\$ 44,999$ & 8 & 27 & $5 \%$ \\
\hline$\$ 45,000-\$ 49,999$ & 9 & 25 & $5 \%$ \\
\hline$\$ 50,000-\$ 59,999$ & 10 & 48 & $9 \%$ \\
\hline$\$ 60,000-\$ 69,999$ & 11 & 39 & $8 \%$ \\
\hline$\$ 70,000-\$ 79,000$ & 12 & 32 & $6 \%$ \\
\hline$\$ 80,000-\$ 89,000$ & 13 & 25 & $5 \%$ \\
\hline$\$ 90,000-\$ 99,000$ & 14 & 25 & $5 \%$ \\
\hline$\$ 100,000-\$ 124,999$ & 15 & 31 & $6 \%$ \\
\hline$\$ 125,000-\$ 149,999$ & 16 & 11 & $2 \%$ \\
\hline$\$ 150,000-\$ 199,999$ & 17 & 8 & $2 \%$ \\
\hline$\$ 200,000$ or more & 18 & 9 & $2 \%$ \\
\hline
\end{tabular}


Question 32. "What is the highest level of education that you have completed?"

All participants were asked to answer this question. $N=545$

\begin{tabular}{|l|r|r|r|}
\hline Category & CODE & Number & \multicolumn{1}{|c|}{$\%$} \\
\hline Less than $9^{\text {th }}$ grade & 1 & 12 & $2 \%$ \\
\hline $9^{\text {th }}$ to $12^{\text {th }}$ grade, no diploma & 2 & 11 & $2 \%$ \\
\hline $\begin{array}{l}\text { High School graduate } \\
\text { (includes GED) }\end{array}$ & 3 & 184 & $34 \%$ \\
\hline Some College, no degree & 4 & 83 & $15 \%$ \\
\hline Associate's degree & 5 & 35 & $6 \%$ \\
\hline Bachelor's degree & 6 & 130 & $24 \%$ \\
\hline Graduate or Professional degree & 7 & 90 & $17 \%$ \\
\hline
\end{tabular}

Question 33. "Which category(s) best describes your main ancestry?"

All participants were asked to answer this question. SUM is the total of all responses coded "1" and reflects the number of respondents in each category. $N=542$

\begin{tabular}{|l|l|r|r|r|r|r|}
\hline Description & DATA CODE & MEAN & $\begin{array}{c}\text { STD. } \\
\text { DEV }\end{array}$ & MIN & MAX & SUM \\
\hline American & ANAM & 0.60 & 0.49 & 0 & 1 & 325 \\
\hline Dutch & ANDUTCH & 0.02 & 0.15 & 0 & 1 & 12 \\
\hline French & ANFRENCH & 0.03 & 0.17 & 0 & 1 & 16 \\
\hline German & ANGERM & 0.22 & 0.41 & 0 & 1 & 119 \\
\hline Irish & ANIR & 0.11 & 0.32 & 0 & 1 & 62 \\
\hline Scottish & ANSCOT & 0.04 & 0.20 & 0 & 1 & 23 \\
\hline Scot-Irish & ANSIR & 0.06 & 0.25 & 0 & 1 & 35 \\
\hline Italian & ANIT & 0.02 & 0.15 & 0 & 1 & 12 \\
\hline Polish & ANPOL & 0.02 & 0.15 & 0 & 1 & 13 \\
\hline Other & ANOTH & 0.08 & 0.27 & 0 & 1 & 44 \\
\hline
\end{tabular}


Responses under "Other" or Comments, Question 33. $N=44$

- American Indian

- Appalachian White

- Asian

- Belgian Welsh

- Cherokee

- Croatian And Lithuanian

- Danish

- French Canadian

- French/Irish

- Greek

- Heinz 57 (Scotch, Austrian, And Polish)

- Hodgepodge Of All The Above

- Hungarian

- Hungarian

- Indian

- Korean

- Latvian/Danish

- Mexican W Native American

- Native?

- Native American

- Native American

- Native American
- Native American

- Native American

- Native American; Indian Cholktall

- Norwegian

- Russian

- Russian

- Slav

- Slovak

- Slovenian

- Swedish

- Swedish

- Swiss

- Swiss

- Swiss And Chinese. However I Was Born In America

- Thai

- Unanswered

- Welsh

- Welsh

- Welsh

- Welsh

- Welsh; Swedish 
Question 34. "Which sentence best describes your residence in WV? Please check only one."

All participants were asked to answer this question. $N=546$

\begin{tabular}{|c|c|c|c|c|c|c|}
\hline Description & DATA CODE & MEAN & $\begin{array}{l}\text { STD. } \\
\text { DEV }\end{array}$ & MIN & MAX & SUM \\
\hline $\begin{array}{l}\text { I was raised in WV, and at least one of my parents was raised in } \\
\text { WV. }\end{array}$ & RESPARENTS & 0.68 & 0.47 & 0 & 1 & 372 \\
\hline $\begin{array}{l}\text { I was raised in WV, but neither of my parents were raised in } \\
\text { WV. }\end{array}$ & RESME & 0.05 & 0.21 & 0 & 1 & 25 \\
\hline I was not raised in WV, and I came here to farm. & RESFARM & 0.07 & 0.26 & 0 & 1 & 39 \\
\hline I was not raised in WV, and I came here for other reasons. & RESOTH & 0.17 & 0.38 & 0 & 1 & 94 \\
\hline I was not raised in WV, and I do not live in WV. & RESST & 0.03 & 0.17 & 0 & 1 & 16 \\
\hline
\end{tabular}

Question 35. "Which phrase best describes your ancestors' place in WV history."

All participants were asked to answer this question. $N=541$

\begin{tabular}{|c|c|c|c|c|c|c|}
\hline Description & DATA CODE & MEAN & $\begin{array}{l}\text { STD. } \\
\text { DEV }\end{array}$ & MIN & MAX & SUM \\
\hline My ancestors did not live in WV & ANNOWV & 0.24 & 0.43 & 0 & 1 & 128 \\
\hline I don't know why my ancestors first came to WV. & ANDONTKNO & 0.24 & 0.43 & 0 & 1 & 132 \\
\hline My ancestors came to WV to work in the mining industry. & ANMINE & 0.10 & 0.30 & 0 & 1 & 54 \\
\hline My ancestors came to WV to work in the timber industry. & ANTIMBER & 0.07 & 0.25 & 0 & 1 & 36 \\
\hline My ancestors came to WV to farm. & ANFARM & 0.31 & 0.46 & 0 & 1 & 169 \\
\hline My ancestors came to WV for another reason (please specify) & ANWVOTHER & 0.08 & 0.27 & 0 & 1 & 42 \\
\hline
\end{tabular}

\section{Responses to "Other", Question 35, $N=26$}

- 1760 came for land grant

- 1805-not sure why - looking to sustain themselves in a new land, farming, timbering whatever it took.

- Both my parents were born and raised in WV.

- doctors
- employment

- farm and work

- from Germany to earn living

- Gensing gathering

- get away from city 
- how should I know

- job

- Land Grant for serving in the Wars

- land grants for fighting in the French and Indian wars (Lord Fairfax lands)

- not sure why

- $\quad$ oil and gas industry

- pioneers 1700 s

- railroad

- railroad employed
- railroad employed

- railroad employed

- reservation

- rigbuilding and farming

- They came here in the late 1700 's as Dunkerd preachers! then became farmers and carpenters.

- Trail of Tears

- war

- work for Union Carbide

Question 36. "Please tell us what kinds of initiatives or programs would help you in your farming or gardening operation. (Examples could include programs, workshops, trainings, handouts, connections to resources or markets, other, etc.). Please specify the topic area or need that you believe needs to be addressed."

All participants were asked to answer this question. $N=405$

- $\quad$ high tunnel exhibits, discussion groups for young farmers

- distribute: row cover, plastic mulch; drip irrigation; plastic; hoop frames - without cumbersome (NRCS etc.) gov't programs - put the tools into the hands of the farmers. Enough money is spent on educational programs and technology. Farmers need tractors without debt. don't show us what to go borrow money for. help us get it - what about a clearinghouse for used equipment. help the ones who haven't got help yet. 2) deregulate - work toward de-regulation. review how dhhr rules destroy small farmers ability to compete. 3) advocate for farm tax reductions - farming takes resources which give small yields - taxes are often unfair. farmers aren't oilmen!

- I attended the small fruit classses in 2012 - good information. 2. the literature they used (the Storey how to raise books were good) and very informational. These were a help and would be for vegetables too. 3. a help to me would be able to rent a 3 hitch no till seeder. approx. 6' for pasture and hay seeding. wat's available to rent is 10' wide - too wide for me. 4 . some how to raise classes - on using plastic and drip irrigation and equipment maybe to rent to lay this. 5. to see a go between for farm to schools. - produce a list for farmers to know what they want instead of just hearing 'we will take all you can raise'. the farmer needs to be on the same page. what, how much is enough per week/month?? and remember the farmer is not helping themselves by spending $\$ 30$ to $\$ 40$ to sell $\$ 30-50$ of product for 3-4 hrs work.

- lower real estate taxes; mine increase $8 \%$ per year. 2. elimination of excess sale tax or 14.2 cents per gallon of off-road diesel. Other state like maryland do not have this. 3. a local place where you could buy ag containers like bushel baskets, strawberry baskets, tomato baskets, corn sacks and such.

- soil/agronomy/forage workshops would be helpful as long as the speakers are tops in their field and the workshops are detailed orietned not just skim the surface; 2 . hands-on website and marketing classes that do not include farmers markets as the only means of selling. 3. 
Organize buying coops for inputs. 4) greater access to programs through all agencies - ie training classes/handouts on what is available and who to contact.

- 1.regional marketing/distribution system to reach larger metro/tri-state markets. 2. require gmo labeling on gmo products. 3.

workshops/training on alternative organic certification (usda organic certification not favorable for a small diverse crops farm). 4. access to rental of farm equipment/some specialized equipment. 5. buying cooperative for equipment, materials, tools/seeds, 6 . low cost water quality testing. 7. group insurance program. 8. program to connect farmers with young folks, internships/work exchange. we have plenty of land - need young/willing workers.

- a community composting facility would be very welcome

- a guard dog program sponsored by USDA/APHIS

- a larger green house; more programs; free handouts; getting our goods into local stores and school (in season).

- a need exists for technical training from cooperative extension service, WVU college ag, WVDA, USDA, NRCS, FSA, Wvconservation agency. Federal and state cost sharing programs are essential.

- a place to process food - frozen and canning. More training and connection to resources.

- a program that would help get ride of the brush brought in; like multiflora rose autumn olive.

- a program to help with lime and fertilizer

- a vegetable auction would help a lot. If we had 40-50 acres combined among growers we could have one.

- A workshop on strawberry production. Pamphlets on various sources for farm financing. References to the nearest provider of services that are not currently available in WV ie field tiling, grain storage guidelines.

- absoluttely none- unless you can turn back the hands of time

- access to assistance with fruit tree trimming by people who are skilled or supervised specifically in fruit trees

- access to commercial kitchen would allow me to sell foods I make \& can.

- Access to local sources for soil nutrients/minerals.

- Access to markets

- access to shared machinery; connecting to buyers

- advanced cattle production classes similar to Kentucky's Master Cattlemen's Class etc. more monies for lime, fertilizer, seed, etc.

- Aggregate farm labor hiring - someone else hires the people, then they are "farmed" out to us to do the work. Kind of like a temp agency for farm labor.

- aggregation

- ALL

- all of the above for farm/garden

- all of the above would help. Biggest problem is fungus and other pest, need more knowledge of prevention. And recognition of pest and disease.

- all small scale to start: 1) beef cattle production - introductory (my mother has taken care of previously); 2) interested in 50/50 fencing fences are in poor shape; 3 ) poultry production for meat; 4) pig production.

- also more government aid for small business farms and also this would promote agriculture businesses throughout communities. 
- An aggregator to help pre-sell product to the school system and commercial accounts with a store front for other VAP

- Animal processing facility

- any kind of education - we have attended several local events put on by the extension office, always very helpful; a specific topic of interest to us is pest management - understanding life cycles, etc.

- any new methods to increase production of blackberry plants. Also insect control of garden pests with less chemicals

- any training on niche crops (mushrooms) pests (stink bugs and deer) organic soil enrichment and native flowers.

- any training that would benefit a small-scale farmer. Workshops that were hands on.

- anything that uplifts the spirit, connects us with each other in the spirit of support, and teaching to farm in a way that leaves the land nourished

- anything that would help in marketing grassfed beef and corn-fed beef

- as far as I can tell with my limited contact, programs are in place to cover most of the needs I am aware of - if anything better advertisement of grants and programs available.

- Assistance in getting land and equipment programs where farmers create a cooperative and co own equipment or help with assistance on getting these in other ways

- assistance with fencing and equipment. I am a 66 year old female with nearly no assistance and deer and other varmits are a real problem. Making it impossible to succeed with any sort of vegetation, berries, fruit, vegetable, and even ground cover or bee forage vegetation.

- at my age I'll involved myself in gardening programs crafts etc.

- at this point (you notice my age) I do not need help as I am working and producing less and less.

- bee keeping

- beef management programs

- Beef operation programs

- better access to resource and markets would be a great help; over the years I have had to do a lot of foot work and been told no! more than a $3 \mathrm{yr}$ old child. But ive managed to find enough market to mark my sales and grow to where I am now. Some help would have really saved me a lot of time back then.

- better understanding of soil samples and how to treat for specific crop

- born and lived on this farm my whole life and at 89 years I am wearing down. I have been to some workshops on behive they would be a great help.

- bulletins, displays, workshops

- Buy Fresh, Buy Local. A real PR campaign to promote buying fresh, local food for better nutriton, for ecomonic reasons to keep the money in the community, for better overall health.

- buy local campaigns; consumer education about local/fresh/CSA/farmers markets; cooperations to pool resources/buying power/selling contracts

- can not think of any at this time

- cattle grazing workshops center of the state ,Glenville or Flatwoods general farm workshops farm management, tax workshops, basic veterinarian access and affordable broadband from frontier. 
- Closer availability of organic compost and fertilizer products

- Composting

- computer training; management of fruit trees.

- CONNECTION TO MARKETS

- connection to other markets and programs and/or workshop to help me learn more about organic farming and gardening.

- connections to funds for infrastructure and equipment

- connections to markets

- connections to markets and processing facilities

- Connections to markets, statewide distribution network.

- connections to resources and handouts

- connections to resources and markets

- connections to resources and markets, workers to hire

- Connections to resources and markets...

- connections to resources and markets; handouts.

- Connections to resources and programs/workshops for grass/grain fed beef.

- connections to resources or markets; cost sharing programs

- Connections to resources would be great...but I especially need connections to useful labor and TIME!!! I could do so much more, but lack time.

- connections to resources.

- Consumer education on health and economic benefits of eating locally. Better access, hours, and venues for local folks to buy local produce.

- continue to make the annual small farms conference vibrant and cutting edge but hopefully no more expensive to attend. ; work on developing more small aggregation packaging storage facilities; more access to hands on workshops on various topics; handouts and pamphlets on newest ideas always a help.

- co-ops, marketing strategies, how to wholesale product.

- cost share program on lime and fertilizer

- Cost share programs Connections to other markets Workshops/trainings for vegetable/fruit farming

- Creating a profitable road-side or farmer's market stand. Legal requirements of selling produce, eggs, and other farm products.

- Limit EPA control

- Dairy Workshops, specifically cheesemaking connections to markets or possible market areas

- Deer control

- development of high tunnel; financial assistance in producing a product for sale; I have 1. vmI certification for producing product; 2 serv safe certification; 3 health approved facility for production.

- dinner meetings - with no charge to attend. 
- direct marketing of farm products to packers, canneries, etc. diversity of ways to bring in income so my children might be able to live on the farm and farm it. More information on using farm as agritourism, hunting commerically, raising specialty meat animals. I'd love to farm fulltime but the cost overcomes the income. ive worked the farm and a full time job all my life and now the government regulation is really putting the squeeze on small farmers. we can't make a profit on the scale that i can take care of the land and animals.

- Direct Marketing Training is needed for WV Agribusinesses. More comprehensive studies on how the food chain in WV works and who are the major players. There are many small coops that work together but there is still no easy way to get foods produced from one part of the state to another. Most of our produce is sold out of the state for that reason.

- discounts on lime/fertilizer; less restrictions on selling dairy products; unsure of anything else.

- ease of marketing, I have no interest in sitting all day at a farmers market to net $\$ 20$. We are artists, primarily. Our food is a form of art, too. At the rate of say 6 jars of canned goods, specialty canned goods, a day selling has to be worth it. Our food is appreciated by friends and family, sought after as low salt, low sugar, fresh home grown. it is expensive to make. but $\mathrm{i}$ want to see others, not as demanding as $\mathrm{i}$ am, make a living at this. so help them.

- educating the general public that locally grown produce is the best.

- eliminate a large part of competition from entitlements for none productions; I employeed 15-25 men for 60 yrs. I gave up 4 licenses in 2012. have 16 left. I take classes and pay fees to keep licenses. (why?). An amish man makes $10 \%$ of what his neighbor gets for a disability (why?).

- elimination of unfair trade practices and policies driven by hoghead politicians, lobbyist and the super wealthy that buy the government.

- end agricultural payments/subsidies, which primarily benefit large corporations. This would raise food prices to real market levels which would then make the smaller family farm sustainable once again.

- EQIP programs, NRCS programs, would like access to community kitchen/ frozen food processing.

- excessive or unnecesarry regulations

- expanded infrastructure programs like high tunnels. I built one with USDA 70\% cost share. I'd build more if add'l cost share was available. Renewable Energy - current USDA REAP only provides $25 \%$ cost share and is administratively burdensome

- expanding markets to have more opportunity to sell produce.

- expansion of online availability of information, downloadable programs/workshops on ways to reduce energy inputs and minimize travel time and expense. Workshops on digital record keeping and how to use for management decisions.

- extension workshops, farm bureau training, agricultural education programs

- Farm Marketing, Funding, Implementation, Working with regulators to make realistic connections between farmers and consumers

- farm markets are for farmers only. (maybe a specific other day for them to come).

- Farm to School opportunities

- farmer markets prices one way too high for seniors. Be nice if we got a discount at the markets.

- farmers market workshops; farm to restaurant workshops, farm to school workshops, safe handling practices in farming of foods.

- farmers markets that only allow local produce. Markets in mineral county allow people to buy from other areas and sell $100 \%$ of produce bought out of county

- farmers need more programs and grants which are more easily obtained. 
- farming is an enjoyable but not profitable endeavor for us. We will continue to farm small scale as it provides fresh beef and produce for us to consume. We have learned through experience, shared knowledge from others, self-teaching through literature what works for us. we consider ourselves stewards of the land not owners and will leave our farm in better condition than when we acquired it.

- fencing workshop, natural insect control training, natural garden pest (mammal) control

- Fiber processing and product development and sales

- Financial aid and more online resources.

- find young people wanting to learn farming and match them up with farmers.

- food safety awareness for customers

- food vouchers for produce that is grown by WV farmers

- forage test plots; more research for chemical controls of insect problems. Weed problems with results. Ia $\mathrm{m}$ not interested in organic farming nor impressed with what I have seen of it in our area.

- FSA programs; WVU extension workshops - beef and swine management; Small Farms Conference - management and marketing programs on how to deal with EPA, DEP, and USDA

- get all the dead weight out of washington. To me that's all the elected officials and put all farmers in there place. People in Washington do not have any idea about farming but yet they are telling the farmer how to farm.

- get more young people involved in raising produce

- get price of medications and package bees down.

- get the government out of farming

- good location for farmers market; better advertisement

- Good prices and good markets

- Government assistance in finding labor. Fuel and fertilizer cost sharing program.

- Grant programs for ponds. soil amendments, fencing and equipment.

- grants

- grants

- greater profits on produce and where to market produce for greater profits

- greenhouse/irrigation/fencing

- handout information is beneficial; proper connections to know the right time and locations to sell cattle and hay to receive best prices; less government restrictions.

- handouts

- handouts

- handouts - pertaining to garden crops. Extension bulletins.

- handouts on specific topics area related blights soil preparation etc. connections to resources for trading plants, etc; programs to help disabled and low income to obtain supplies or purchase produce in limited funds (and the producers benefit also somehow) WIC and SR Citizens leaves out greater than 5 and less than 60 .

- Handouts or mailings regarding pest control, especially deer, potato beetles, etc. 
- handouts, workshops

- handouts; connections to resources or markets; updates in magement of chemicals for our particular use; guidance to improve marketing; how to prepare product for the general public.

- hands on workshops; cost share assistance on equipment and facilities; better markets

- having access to local programs, like Braxton co "Dig it" seminar. Also, a better understanding of where many of our seed products come from and how they originated (such as hybrids, heirloom, and non-GMO)

- help on farm; handouts

- help with finding reasonable priced lime fertilizer not chicken liver. I'd be open to all kinds of workshops \& trainings. I've attended tree /pine pruning hand on training. I've attended blueberry seminars. I participated in master gardener training and grow Appalachia. they've all been very helpful. i need more training in running a business and understanding the legal requirements, federal and state.

- help with how to best put together a plan or blueprint of how to make our farm as self-sustaining as possible. Help with funding or programs to install solar and wind power. Encouragement to keep going (for my husband and i) and encouragement for my children to take a leap of faith and choose and simpler, harder, less monetarily rewarding life in the hopes they will save their sanity and their souls. :)

- high tunnel - with little or no out of pocket expense; master gardener course - in clay county; farmers market in clendenin

- high tunnel cost sharing

- high tunnel help; deer protection farm damage

- how do full-time workers off the farm successfully transition to full-time farming? Some strategies and best practices for this type of transition would be wonderful. How soon could one replace income by farming full-time?

- how to avoid GM foods less government control, WV please control wildlife.

- how to better manage a CSA, planning, budgeting, marketing. A good local bull test program

- how to control potato bugs and stink bugs. What can be sold at farmers market such as ingredients need to be listed in jellies and bake goods.

- How to fix soil problems. Especially for organic growing. I would like to know more about calcium and I want to know how to balance the minerals in the soil.

- $\quad$ how to increase value received from farm produce at local level.

- how to make a pond accessible for garden with very little expense. How to keep deer out of garden, we tried deer netting, without going to expense of fencing. Something that doesn't cost a lot because I am on limited income.

- how to market local produce for maximum profit; and how to help people appreciate the benefits of local produce.

- I am currently retired and do not plan to expand my gardening.

- I am targeting the BOE as a primary customer. Sooner or later I will have to have GAP training to maintain that business. I am a small operation and worry I will not be able to afford GAP certification.

- I believe a workshop training session on hydroponics would be a useful project. Maybe offered through Extension service in the same format that master gardeners is offered. Should be simple setup that is easy on the pocketbook. 
- I believe that the spraying pesticides along road ways and right of ways when plants are in full bloom is wrong because I believe it is killing both birds and honey bees. Should spray before the bloom is out and after the bloom is gone. I'd like to see a law passed to control that. Thanks.

- I believe the state provides ample programs for producers to attend

- I can't really think of anything but that the price of seeds, feed and fertilizer is getting too high for people to be able to raise anything. The government needs to help the poor that want to work. The wages don't go up but everything else does. It's very discouraging.

- I can't think anything that is not being done at this time. The extension office does a great job and answers most all of my questions.

- I could use a high tunnel or small greenhouse.

- I enjoy the workshops and training that the WV Extension has done in the past. Haven't always been able to attend, but wanted to. Dinnermeetings are good etc.

- I feel that we have plenty of opportunities. The Clay extension office is very active. I just have problems finding time to pursue all of the workshops that would help me.

- I feel WVU Extension and the Small Farm Conference provide a lot of what I would need but having time to attend is the problem

- I had plans for a petting zoo of just small farm animals such as goats, children, rabbits etc. but found out permits are too difficult and expensive.

- I have 2 acres cleared with forest all around me. Wildlife, insects, disease are my biggest problems. These problems cost a lot of time and money to overcome. This limits how much food I can grow more than anything else. I want to grow food as naturally or organic as possible without great cost of time and money it now takes. There is a lot of information on this subject, but it is very costly to overcome.

- I have attended several workshops on low tunnels, high tunnels, and season extension. They have been helpful.

- I have completed the master gardener program and participate in at least 2 classes offered each yr for the past 3 years. I have attended the state master gardener conference and small farm conference 2 years. I receive educational information from my extension agent and the food and farm coalition. i believe i know where to get any information i need but i would love to see an email blast from the small farm center with any seasonal information on produce production or practices.

- I have got a lot of good out of the workshops on high tunnels growing in the fall and winter

- I have looked at starting some type of miniature beef cattle operation but I would have to invest in fence and I would have to learn about care of cattle.

- I missed the schooling on high tunnels because I was sick. I could use info on high tunnels.

- I need more marketing skills spent my life as a professional carpenter

- I raise fall mums and honey bees would like to see more workshops on these.

- I see plenty of all of the above available. Closer relations during the growing and off-season with experienced organic farmers or gardeners who have some time to spare with advice, especially immediate problems of the time.

- I think that current initiative to encourage home gardening and to supply schools local restaurants and local citizens with locally grown food are excellent. I would like workshops on gardening methods, new ieas. I have attended some in the past.

- I think there are a lot of programs and resources available already by the state and federal gov. The small farm conference and PASA offer about everything you could need so I'm satisfied with what is going on now in that way. 
- I think wvu does a pretty good job of supporting beef cattle farming in WV. Along with FSA and soil conservation districts.

- I wish more research were done on goats - I don't like that I use cow products off-label; I could use a good list of open-pollinated vegetable varieties that do well in WV. And sources of untreated seed for those varieties.

- I would be interested in workshops. I am always open to good advice and learning more about raising crops.

- I would like anything for 'free'. Seriously, I would like an outlet for my produce and would like to share the fact more people should go organic for our planet and for their health. I would like to save as many seeds as I can to save money and have true organic seed.

- I would like more information similar to what I find in the farmers almanac. Lunar cycles and such.

- I would like to have access to bulk packaging. If we were able package some of our produce perhaps we could market to local grocery stores. I would also like to see more work done to make the farm to school program come to fruition in our county.

- I would like to have access to farmers coop, csa, class on tips/techniques on how to garden/market.

- I would like to know if there is a grain buying elevator in wv and a hay auction in wv so I don't have to sell out of state.

- I would like to see more people consider raising for farmers markets and school food program. (4-h garden) and ffa projects. Need the youth to grow their own and use fresh - not grown in store!

- I would like workshops or training to better myself as a food producer. Organic gardening is important to me for my family. There is so much I don't know. Also about grass-fed beef and chickens.

- I would say that I am very fortunate to have the county ag agents between berkeley and jefferson counties to help have workshops and dinner meetings to keep me up to date on the latest of the cutting edges developments, regs, and continuing ed. I could ever ask for. and if i cannot find what i need - all i have to do is call or email one of them.

- I'm always interested in learning more about gardening. I would like to learn about raised-bed gardening. I feel like raised-bed gardening would be easier for me to handle by myself. I am also interested in high tunnels, hoop houses, and greenhouses.

- in this area we need more training. Handouts to get more seeds to plant workshops be great to have around.

- in ways that the farmer can keep interest from family members in the work

- incentive programs, local ad papers, radio station, bimonthly magazine with tips

- increase amount of senior and WIC coupons for farmers markets

- It would be helpful to have email notifications of market opportunities or a monthly calendar. Workshops for gardeners would be helpful to include seed swaps, information sharing, and training.

- it would be nice if there were more resources available to organic gardeners including workshops training and market connections

- keep on with programs that work; we need to teach our youth how to survive if necessary, in a self-sufficient manner; our schools need to be in our communities and stop bussing for $2 \mathrm{hr}$ to try to get an education. Without our school our heart beat is altered and our community destroyed.

- Knowledge is always good.

- larger area for farmers market

- leave me alone and quit sending me census questionnaires repeatedly after I have already filled them out and sent them in.

- legal assistance, financial assistance

- less government regulations and harrassment; lower taxes 
- Less rules, regs: more emphasis on less use of pesticides, etc to the gen public through training and media

- like the various dinner meetings with variety of speakers

- lime and fertilizer programs handling facility program

- literature on plant disease and what to do also what fertilizer to use on what plants

- livestock programs; pasture programs

- loan programs to get a family started in farming markets which maybe interested in buying directly from a grower, which would increase the quality of foods cutting out the middlemen more state or county programs that would encourage people to grow foodstuffs, they give away all sorts at non-food trees but only offer fruit trees and berry vines at a high cost. Clear training on (...) requirements and legal perils.

- loans and grants for young farmers trying to make it as farmers. Maybe a program that would team an older farmer with a younger farmer to help with hands-on stuff and help start them in right direction.

- local buyers markets direct to business or wholesalers, processor markets

- Local food alliances, greater use by local restaurants

- local grower co-op

- local water testing; pond and fish maintenance.

- LOCAL WORKSHOPS TO INCORPORATE HIGH SCHOOL STUDENTS WHOSE AG PROGRAMS ARE BEING DROPPED THIS SUMMER.

- Locally offered course on farm business management. A statewide small farmer produced newsletter or magazine. Health insurance plan for farmers.

- low cost grants or loan program information

- low income programs and self-help workshops

- mail publications - handouts on home gardening. Don't have time to attend workshops.

- Make it easier for farmers to sell canned produce in this area or further afield

- make the sell of raw milk legal!

- Many programs are already in place. Time management and adequate help for the small farm needs addressed.

- market connections; animal control

- market connections; state funded programs; bringing farmers together to share equipment/land; community education.

- market development and access, niche production to match available resources (what is best suited for me to produce given my location, type of land, lay of land, and labor situation)

- marketing

- marketing

- marketing of our cattle online. We do not have any knowledge as the best way to accomplish this.

- marketing organic/natural beef

- marketing products, educating public on the benefits of buy fresh by local, the ability of our farm to accept food stamps

- marketing techniques; money management

- master garden with WVU Extension 
- master gardener, fruit tree knowledge, online connections, market connections

- meat goat/cattle operation for parasite control; high tunnel production methods to increase yields; vermiculture in high tunnel uses.

- Mentorship for new ventures - examples: growing crops in high tunnels managing cattle for beginners

- money is a large initiative; not feeling my age is too; but most of the time I do feel my age and then some.

- Monroe County has a young and healthy growing farmers market. It is really beneficial to me as a producer. Our market sells mostly to individuals and restaurants in Charleston and Lewisburg. I would really like to see our local farmers market, for Monroe county residents, become more active and more involved with or own residents. The demand for local food by local citizens is just not that great at this time, but hopefully we will improve in this area in the future.

- more access to programs and training; more grant availability; more help with marketing; more knowledge and community leadership in utilizing the benefits the farmers can offer the community and the community can offer the farmer; less bureaucracy from state/local government to allow small farmers to succeed.

- more advertisement

- more advertisement, I had no clue about our local farmers market 3 years ago; now I tell everyone about it.

- more availability of custom meat processors.

- more connections to markets/more places to market the produce when it is available.

- More cooperative marketing - more wholesale or group marketing of products - 30 years ago we produced 100 dozen ear of corn per week 2 month season. 20000 peppers 3000 tomatoes approx 1 acre of miscellaneous produce, beans, brocoli, cauliflower, beets, turnips etc. we couldnot sell sufficient volume retail to be profitable. i quit largely selling livestock directly due to the high cost to market. $\mathrm{i}$ would need a significant promise to do this. the problem with direct or farmers market sales is even if the profit percent is high you can only sell a limited number of fruits. you need to make a certain amount of money to pay the bills which requires volume with lower maybe access to services such as veterinarian are a real problem.

- more farm markets

- more farmer to farmer exchanges of information. More support for farmers markets. Subsidies for young wanna be farmers. A rotary loan system for equipment purchases.

- more fertilizer and lime seedlings and seeds should be available free or at a reduced price for low income people such as disabled elderly of WV. Gardening is a great hobby and helps them have fresh produce and something to do exercise.

- more information for the small farmer on selling at markets, liability for products sold, workshops for young farmers just starting out,

- more information on raspberries and other small fruits. Organic pest control information.

- more interest in our local farmers market. More funding for equipment such as high tunnels, greenhouses, seeds, trees, plants, etc. Education for children in schools or other programs to teach gardening.

- More local marketing initiatives for my area.

- more local net-working with local growers and workshops

- more local workshops and trainings

- more marketing information and growing information related to high tunnels. Ex. When to plant what and what varieties work best.

- more meetings on pesticide and herbicide management. 
- more of an accurate portrayal of the different beef types in advertising.

- more on how to raise a garden. More on raising pork and beef

- more programs and workshops closer to my county that I live in (fayettte) on gardening and canning

- More programs for cattle operation. Diseases that cattle can carry and yearly vaccinations needed. More information on farming news and resources to help farming.

- more promotion of just how important it is to buy local and eat farm fresh, a step above the rest!

- more property

- More training on the latest in row crop production for corn and soybeans

- more workshops on berries production

- more workshops on pesticides - herbicides training

- more workshops with the topic of pest control and irrigation

- most people who raise sizeable gardens grew up on family farms and therefore have learned most of the necessary working for best results as to planting tending and reaping and using the vegetables to the fullest extent.

- Multi-media skills, Computer skills, Business Skills

- mushroom log workshop, high tunnel grant workshops for funding and expansion, invasive species training. Food cost classes wild foraging classes - dos and don'ts. Community supported agriculture expansion. Closer packaging facilities.

- My age and physical ability limit what I can do. I am not interested in hiring help or expanding. I profit very little for my labor, but I do maintain a nice place to live. I do not know of any help I need.

- my husband and I are both disabled so our children help as much as they can to grow a garden have milk cows and raise our own beef. When we have more than we need, we sell that for extra income.

- my wife handles the sheep, any classes on sheep, health, marketing, breeding, anything in this area would be helpful. We have attended some calsses on farm to table. We are looking into some hydroponic or aquaculture, we are in process of putting up a greenhouse.

- Have fruit trees that need help. Have diseases that I have to identify and cure myself. Have vegetables that bugs and disease I have to figure out myself and companies sale their products with great words. What do i know?!

- need food processing plant so that produce would be available out of season. Ie. Canning/freezing.

- need to find something to get rid of potato bugs; they are in the ground when you plant a lot of sprays don't really get rid of them. A workshop on the study of bugs would be helpful.

- need to lower price of gas - and fuel - and also the cost of fertilizer.

- newsletters; programs

- no handouts unless the people are really unable to work. No work, no eat!

- no idea

- no taxes, \$

- none. We have found that the best information we got is from speaking with other farmers - experience goes a long way and we try to read as much as we can, but our time is limited. Thank you. We know we're not going to get rich doing this, we just wish to do what we enjoy 
doing and raise our kids on our farm, hopefully with good values. increasing costs of health insurances crops and ferilizer concern us but we try to find alternatives and ways to get through it.

- nothing for myself and spouse.. But we definitely need more program and education for our young folks and it needs to start at an early age. Need more programs for the high schools, etc.

- nrcs high tunnel grant; I am very satisfied with the programs, workshops, that my extension agent has been providing as well as the wv small farm center and conference.

- Old Farmer to young farmer land use program, any grants to help with setting up a CSA, equipment borrowing through WVU Extension.

- on farm halal slaughter; better way to lease land; pool listing.

- one of the things I would most benefit from is an effort to raise the number of pasture-raised birds which can be processed at home from WV's current 1000 closer to the federal guideline of 20000. it would open a lot of marketing opportunities, similar to what exist in VA.

- our primary product is beef cattle - genetics to improve quality, herd health. To save time - training programs via the internet would work best - traveling to meeting places is too time consuming.

- Outreach to public through events, programs via connection with existing organizations

- people need to realize good local food cannot always be the cheapest

- permission from DNR to kill bears that have ruined my crop season three years in a row.

- Pest and disease control chemicals available in small quantities at reasonable cost. An example is that I must purchase some products in $50 \mathrm{lb}$ bags when I only need $10 \mathrm{lbs}$ per year.

- $\quad$ pest control

- pest control for home gardens and orchards. Chemicals that are available to the home/small operation. I could not get the online survey link to work either. An easier onine process would be better.

- processing kitchen to addvalue; advertising - getting word out that once raises plants and produce for sale. A viable market location available 7 days a week thu season and off season for processed goos and high tunnel goods.

- Programs and workshops

- programs on cattle vaccination and connections to other sources of marketing for cattle other than the local stockyard. A more dependable price market.

- programs on planting and caring for food

- programs that highlight specific varieties for vegetables that produce well in my area. Tomatoes, potatoes, sweet corn, etc.

- programs to help farmer learn what aid is available and the resources to sell products. resources to make it easier for farmers to sell process/canned and fresh food

- Programs to reduce cost of garden seed and cost of livestock feed

- Project Annie was the best program that I have come across yet.

- promote local farmers market. Don't over-burden people with rules and regulations. I fear the GAP program could be devastating for small growers if it becomes mandatory. Workshops in high tunnels, vegetable production would be helpful. Please schedule them in the offseason so people have time to attend.

- Promotion of local garden markets. Basic gardening programs and workshops would be helpful. 
- resources/training financial resources

- resources to clear more land for production but retain acres in woodland for wildlife, hunting.; especially markets to sell superior nutritional products

- $\quad$ seasonal planting

- Services to help with drainage landscaping and soil nutrient programs ( lime-fertilizer ) cost assistance.

- $\quad$ should regulate the prices at market; instead of price gouging

- $\quad$ silviculture \& aquaponics distribution resources

- $\quad$ something to teach our city people to support local grown. Because the small family farms are disappearing every year.

- $\quad$ starting and learning about greenhouses, hoop houses, organic pest control in the garden.

- $\quad$ state assistance to treat bee colonies for mite and disease

- State support for Farm 2 School programs through access to resources, trainings for school board \& community members, resources for building infrastructure (ie. distribution centers, community commercial kitchens)

- $\quad$ support from WVDA for farm markets; have them work with local, county and state organizations that have regulations prohibiting farmers markets and on farm markets from having signs along roads etc so customers can find them. Having health department regulations for farmers markets - we are not restaurants - so that we can give customers samples of what we grow (slices of melon etc.)

- talking to others in the farmers market. Listening to older farmers about how they used to farm and get pointers.

- tax free low interest farm loans

- taxes too high; I don't do internet; thank you.

- the agricultural agent for the county sends information regarding many opportunities for workshops and meetings throughout the year which is helpful. I would like to have more specific planting and pruning information for my area.

- the availability of financial help so as to not have to sell a lot of the breeding animals to keep the farm as a whole when prices go down.

- the comment doesn't have much to do with this stuff. I'm a self-taught gardener; I've read tons of books. And did trial and error in my garden. I've had great success companion planting should be used more extensively in other people's gardens. I like hearing how other people do their gardens and hearing about their experiences. $\mathrm{i}$ went to the small farm conference in morgantown 3 yrs ago. it was very intereresting. but i haven't been there again; some gardeners and farms could use info on secrets of mulching, companion planting, use of soil amendments, etc. then they wouldn't have to use chemicals in their farming and gardening.

- the farm that I inherited needs a lot of work. It is back in the holler. Would love to have access to city water. Instead of us having to fill out grant applications which by the way are way too complicated, grantors should come to us to see what plans to make us bigger or banks backed by the government. better roads and a bridge because of high water is badly needed, cracks need to be cleaned out and there is an abandoned road past my house that needs to go back to me cause the road has washed away.

- the garden calendar is very helpful and the market bulletin also.

- the government could help the farmer with fertilizer and spray for the (...). The programs (...) would help.

- The permits that I need run from July to July? That is crazy. Why don't they run through the growing season? December to december? They do in other states. Organizing aggregators to purchase from farmers in our area. We are a production center. There are lots of farms producing but a low population center for direct market sales. 
- the use of a hoop house or a high tunnel for earlier and later crops.

- the will to work. Hard worker. Honesty! Farming is hard. Needs to know some mechanical ability, common sense not educated knowledge.

- to have more stuff to offer so they can come to the farm to get most if not all of their stuff.

- to let small farmer or gardener file for crop loss or damage done by deer, or drought, I don't think any person over 65 yrs of age should pay income tax of any kind. They should do more to teach children in schools about growing own food to eat. Have field trips to orchards and gardens to interest them more in planting a seed and watching it grow. It's in my blood.

- Niche markets are fine for a producer that doesn't have the resources to compete on a commercial scale. people can only eat the 'story' so long. we have an opportunity to grow production ag in our area if the right resources can be put together.

- training in raising hops for the microbrew industry

- training information on different programs we would qualify for; handouts

- training on gardening and marketing; hands on workshops - greenhouse and high tunnels; internet sites (learning) - gardening

- Training programs and educational opportunities for ADULTS are important in my area - both production and business/marketing. Also, a community-accessible certified kitchen and trainings on food processing and/or value-adding with support from the health department would be appreciated. Additionally, a publicly accessible post-harvest handling station for smaller, home-growers would be helpful. Not everyone has the infrastructure for washstations, etc. in their own backyard.

- Training, handouts - marketing and business

- training, more information

- training/handouts more help for farmers from the government such as help in equipment and lot breaks. If people don't work we are all going to starve.

- trainings and workshops specific to production agriculture on a small scale

- Trainings are always helpful.

- tried to get a well thru NRCS but didn't qualify; partly because I don't have animals?

- uncertain

- value added products and guidance/assistance with getting funds, training, equipment, marketing, or associated certifications and legal obligations.

- way to process excess fruit vegetable for off season for sale

- We took the Master Gardener class and it has helped us a lot. Workshops would be helpful.

- we are limited only by financial burdens

- we could use a commercial kitchen to process meat and vegetables made available through our local extension service to the public. We have already used and appreciate services through the soil conservation service out of Beckley wv. We need a permanent and well-placed location for our farmers market in Princeton wv.

- we enjoy going to demonstrations locally. I'm not going to travel out of town/county to attend. We've seen things from garden rotation to cattle handling and have benefited from all. 
- We have a program called Grow Appalachia that is supporting local families to grow gardens, with the goal of getting them into the market. It would be great if there was funding for a walk-in cooler that could be built in their building in Hillsboro. Then all the families could bring their produce there one day a week, and the Grow Appalachia program could organize a CSA where people could buy the produce. Maybe someone should publish a book on how to do this and it seems like it would be possible for it to be a business that could hire someone to run it. how do we make sure that the person we hire will be capable of making it work? This seems like the kind of opportunity that should attract an investor who is willing to take the risk

- we have a very good support in our area for the farmers - we always can use more classes of all kinds for our farmers. Even if we've been to a class for pruning plants and trees we will still go to a new workshop that's offered. You can always learn something new and different. money of any kind can be used by all.

- we need a class so we can accept the food vouchers from senior citizens

- we need local (through extension) workshops on "GAP" training - in county - so we don't have to travel so far to get it.

- we specialize in heirloom varieties of bean and tomatoes. Barriers are used in producing jams and jellies which I sell to gift shops, state parks, and local grocery stores. Herbs are used in production of culinary blends and beverage teas also wholesaled.

- we used to get more money for our product and less expense such as fuel and feed and fertilizer

- we used to have meetings about raising vegetables and fruits for the farmers markets and new things that they were learning at the universities they would come and share with us. I don't know why these meetings stopped - I would like to have more info on how to control cutian weeds without using poisonous sprays and control insects better.

- weed control; fertilizer-lime programs; pasture workshops.

- what assistance there is and in what areas

- What kinds of products and quantities are needed at restaurants and for school programs.

- when I farmed in Ok I was able to help the indian nation rehabilitate their recovering drug and alcohol natives through a work program on the farm. I got the help I needed if I was willing to give them a job. Great program as it helped everyone.

- with berries need handout on diseases and with bee keeping the inspection of the bees by the state

- workshops on commercial kitchens

- workshop about soil needs in WV and how to prepare soil. Information about which herbs others are selling. Increased awareness in community of farmer's market and interest in supporting local economy.

- $\quad$ workshop training

- workshop with input of products available to enable the farmer to get a good crop. As how to stop blight mostly.

- workshops

- workshops - dairy goats

- workshops - organic growing techniques

- workshops - training; get youth involved; my son and 2 grandsons are participating in tailgate marketing.

- workshops are helpful and handouts 
- workshops especially online so that I can watch/read on my schedule. Topics - rotational grazing, breeding for parasite resistance, season extension, specialty crop growing, grass based dairying, packaging/labeling and marketing. WV state small conferences have become too expensive.

- workshops for growing fruit trees and gardening. Needs to be a government assistance program to help buy fertilizer, lime

- workshops for pest management

- workshops in marketing; interested in making cheese and how to get licensed. Make good yogurt and hard cheese but can't sell it.

- workshops on animal nutrition

- workshops on cattle handling, programs for use of poor or strip mined land and improvement practices for this land. Aquaculture opportunities and hands on workshops on individual farms.

- workshops on effects of commercially used chemicals used in food production on human health.

- workshops on fertility - selection of seeds and soil types - insect and weed control.

- workshops on first getting started with a greenhouse or small berry operation.

- workshops on gardening and canning and or processing foods from the garden

- workshops on growing home orchards. espalier, cordon, and as well as grafting fruit trees.

- workshops on how to control the coyote problem: rewards or bounty for killing coyotes before they kill all of our young livestock.

- workshops on organic gardening, organic resources are hard to find in our area, more training on SARE grants and people to help you write a SARE grant

- workshops on pest control.

- workshops on season extension

- workshops on small farm operation--cattle, apiaries

- Workshops or handouts in organic pest management, avoidance of plant disease, building and gardening in raised beds, composting using locally available materials.

- workshops or programs. Marketing labeling requirements and pricing.

- workshops related to dairy goat industry; new (changed) laws that allow farmers to sell milk off the farm to individuals for personal use or animal consumption (orphaned cows, foals, etc.) !!! Monetary incentives for farming (increased cost share programs, grants, loans), tax breaks for farmers, incentives to buy and sell locally.

- $\quad$ workshops, classes, on all phases of farming.

- workshops, training, handouts

- workshops,low interest lones

- workshops/trainings

- would be nice to have other farmers market throughout the county instead of only at county seat use of natural pesticides

- would like to train people who would like to know about poultry raising and dairy goat production

- $\quad$ would like training on analyzing farm records for income and expenses

- wv needs to identify volume growers in all areas; business plan development assistance; marketing assistance/marketing streams for those producers not interested in the market aspect. 
- WV residents know how to produce - marketing and distribution is their handicap. I have an abundance of produce however I do not want to sit on a tailgate every Saturday at the farmers market. How do I sell my product with no time?

- year round farmers market; CSAs 


\section{Appendix 4: Counties and states represented in sample}

These tables present the number of surveys sent and received by county and state.

Counties represented in study sample and respondents within West Virginia:

\begin{tabular}{|c|c|c|c|c|c|c|c|}
\hline \multicolumn{8}{|c|}{ West Virginia } \\
\hline County & Sent & Received & $\%$ & County & Sent & Received & $\%$ \\
\hline Total & 1449 & 535 & & & & & \\
\hline Barbour & 44 & 20 & $45 \%$ & Nicholas & 62 & 20 & $32 \%$ \\
\hline Berkeley & 22 & 6 & $27 \%$ & Ohio & 1 & 1 & $100 \%$ \\
\hline Boone & 1 & 0 & $0 \%$ & Pendleton & 1 & 0 & $0 \%$ \\
\hline Braxton & 25 & 12 & $48 \%$ & Pleasants & 11 & 5 & $45 \%$ \\
\hline Brooke & 2 & 0 & $0 \%$ & Pocahontas & 90 & 32 & $36 \%$ \\
\hline Cabell & 43 & 10 & $23 \%$ & Preston & 182 & 68 & $37 \%$ \\
\hline Calhoun & 24 & 9 & $38 \%$ & Putnam & 7 & 0 & $0 \%$ \\
\hline Clay & 29 & 11 & $38 \%$ & Raleigh & 4 & 0 & $0 \%$ \\
\hline Doddridge & 4 & 2 & $50 \%$ & Randolph & 20 & 4 & $20 \%$ \\
\hline Fayette & 73 & 27 & $37 \%$ & Ritchie & 3 & 9 & $300 \%$ \\
\hline Gilmer & 18 & 8 & $44 \%$ & Roane & 37 & 17 & $46 \%$ \\
\hline Grant & 2 & 1 & $50 \%$ & Summers & 16 & & $0 \%$ \\
\hline Greenbrier & 18 & 7 & $39 \%$ & Taylor & 11 & 7 & $64 \%$ \\
\hline Hampshire & 194 & 71 & $37 \%$ & Tucker & 13 & 8 & $62 \%$ \\
\hline Hancock & 3 & 1 & $33 \%$ & Tyler & 13 & 7 & $54 \%$ \\
\hline Hardy & 11 & 4 & $36 \%$ & Upshur & 28 & 13 & $46 \%$ \\
\hline Harrison & 18 & 7 & $39 \%$ & Wayne & 5 & 1 & $20 \%$ \\
\hline Jackson & 19 & 6 & $32 \%$ & Webster & 26 & 13 & $50 \%$ \\
\hline Jefferson & 47 & 13 & $28 \%$ & Wetzel & 4 & 0 & $0 \%$ \\
\hline Kanawha & 7 & 5 & $71 \%$ & Wirt & 48 & 18 & $38 \%$ \\
\hline Lewis & 32 & 13 & $41 \%$ & Wood & 6 & 0 & $0 \%$ \\
\hline Lincoln & 17 & 4 & $24 \%$ & Wyoming & 1 & 0 & $0 \%$ \\
\hline Logan & 2 & 0 & $0 \%$ & & & & \\
\hline Marion & 15 & 8 & $53 \%$ & & & & \\
\hline Marshall & 4 & 0 & $0 \%$ & & & & \\
\hline Mason & 16 & 7 & $44 \%$ & & & & \\
\hline McDowell & 0 & 0 & NA & & & & \\
\hline Mercer & 63 & 21 & $33 \%$ & & & & \\
\hline Mineral & 38 & 19 & $50 \%$ & & & & \\
\hline Mingo & 0 & 0 & NA & & & & \\
\hline Monongalia & 16 & 3 & $19 \%$ & & & & \\
\hline Monroe & 26 & 11 & $42 \%$ & & & & \\
\hline Morgan & 27 & 6 & $22 \%$ & & & & \\
\hline
\end{tabular}


Representation of other states and counties within study sample and respondents:

\begin{tabular}{|c|c|c|c|c|c|c|c|c|c|c|c|}
\hline \multicolumn{3}{|c|}{ Pennsylvania } & \multicolumn{3}{|c|}{ Maryland } & \multicolumn{3}{|c|}{ Ohio } & \multicolumn{3}{|c|}{ Virginia } \\
\hline County & Sent & Received & County & Sent & Received & County & Sent & Received & County & Sent & Received \\
\hline Total & 18 & 6 & Total & 11 & 2 & Total & 21 & 9 & Total & 3 & 1 \\
\hline Washington & 5 & 2 & Garrett & 6 & 1 & Lawrence & 8 & 2 & Faquier & 1 & 1 \\
\hline Greene & 4 & 1 & Allegany & 2 & 1 & Gallia & 6 & 2 & Salem & 1 & 0 \\
\hline Fayette & 3 & 1 & Montgomery & 2 & & Belmont & 2 & 2 & Tazewell & 1 & 0 \\
\hline Franklin & 2 & 0 & Washington & 1 & & Harrison & 2 & 1 & & & \\
\hline Allegheny & 1 & 1 & & & & & & & & & \\
\hline Beaver & 1 & 0 & & & & & & & & & \\
\hline Fulton & 1 & 1 & & & & & & & & & \\
\hline Montgomery & 1 & 0 & & & & & & & & & \\
\hline
\end{tabular}




\title{
Appendix 5: Curriculum Vitae
}

\author{
Ruth Mary Oldham \\ 312 Mulberry St. Morgantown, WV \\ (304) 692-1044・oldhamrm@gmail.com
}

EDUCATION

West Virginia University Morgantown, WV, USA (Present)

Candidate, Masters of Science in Agricultural and Resource Economics

Dickinson College

Bachelor of Science: Environmental Science

Summa cum laude; Phi Beta Kappa

\section{PROFESSIONAL EXPERIENCE}

\section{Mountain Harvest Farm, LLC.}

Co-owner

Carlisle, PA, USA (May 2006)

- Co-own/manage diversified organic vegetable market farm.

Morgantown, WV (Present)

Value Chain Cluster Initiative

Regional Coordinator

WV (January 2013-present)

- Conduct program outreach across $9 \mathrm{WV}$ counties to food and farm businesses and groups

- Assess training and one-on-one technical assistance needs among businesses and groups, draft scopes of work, and recommend types of consulting and technical assistance needed

- Identify potential service providers and consultants

- Coordinate with other organizations and agencies to leverage resources and impact

- Assist in baseline data collection and analysis and routine data collection for monitoring and evaluation

Appalachian Foodshed Project

Graduate Research Assistant

Morgantown, WV (2011-present)

- Prioritized and compiled secondary data for regional community food security assessment

- Facilitated communication between WV stakeholders and regional project management team

- Coordinated logistics of WV participant scholarships and attendance at meetings

- Designed and analyzed survey to assess stakeholder needs and interests

\section{Northeast Sustainable Agriculture Research and Education (NESARE) Grant}

Graduate Student Grant Recipient

WVU, Morgantown WV (present)

- Designed and currently implementing study to analyze producer goals, expansion intentions, and perceived limitations in local food markets in WV.

- Collaborating with extension agents and farmers market managers to survey WV producers.

\section{Project Global Village (Proyecto Aldea Global)}

Volunteer

Tegucigalpa, Honduras (March-May 2011)

- Prepared grant proposals for United States foundations for agribusiness, nutrition, and youth projects.

- Translated English grants to Spanish for local development workers. 
United States Agency for International Development (USAID)

Returned Peace Corps Volunteer Intern Tegucigalpa, Honduras (October 2009 - present)

- Collaborated to design and revise food security and protected areas programs, strategies, indicators

- Developed analysis tools to guide technical staff to integrate gender considerations into programs

- Conducted monitoring and evaluation activities

- Prepared, edited, and translated communications, strategic planning, and foreign assistance documents

- Represented USAID at donor agency coordination meetings and conferences

- Moderated focus group discussions with farmers and 16 donor country agencies (G-16) representatives

- Supported logistics and planning for USAID Mission Director and G-16 donor group field trips

- Designed and led sessions on development effectiveness at final Peace Corps Volunteer Conference

\section{United States Peace Corps}

Protected Areas Management Volunteer

El Cantoral, Honduras (July 2007 -September 2009)

Sustainable agribusiness and irrigation projects

- Improved income and food security of over 20 women by coordinating the development of a new vegetable and herb agribusiness and establishing stable market connections with supermarkets

- Trained members of women's cooperative in skills to manage small agribusiness including production and marketing skills; conflict management; basic accounting; record management

- Developed proposal for a 125 acre drip irrigation system for 60 farmers

Renewable energy, watershed, and potable water projects

- Solicited and managed grant for school solar panel that provided the town's first source of electricity

- Led elementary school environmental and watershed education activities

- Organized and trained local water board to administer water resources and sanitation

- Coordinated the development of a study, design, and proposal for a potable water system that provided more than 250 people with a stable and clean water supply

Training and leadership-related activities

- Facilitated garden management workshop for 20 volunteers and 20 community leaders at 2009 Peace Corps Women in Agriculture Conference

- Instructed over 30 new volunteers in agricultural production cost calculation and market selection at 2008 and 2009 field-based trainings

- Offered emotional support to volunteers as appointed peer counselor

Seitz Farm

Harrisburg, PA, USA (February - May 2007)

- Co-planned and implemented first stages of new organic vegetable market farm development, including direct seeding and transplanting plans, seed orders, crop rotation plans, first plantings 


\section{Sierra Club}

Intern

Harrisburg, PA, USA (February - May 2007)

- Accompanied lobbyist to promote pro-environmental initiatives to state legislators

- Prepared educational materials and logistics for greenhouse gas reduction conference

\section{Bosque de Niebla, Las Cañadas Biointensive Farm}

Apprentice

Veracruz, Mexico (January 2007)

- Maintained crops, compost, and organic soil amendments on organic biointensive experimental farm

\section{New Morning Farm}

Apprentice

Hustontown, PA, USA (May - November 2006)

- Managed production and harvest of various crops on 30 acre diversified organic vegetable farm

- Coordinated and implemented farm-wide integrated pest and disease management, including monitoring and identification, use of preventative biological controls and organic sprays

- Marketed organic produce at biweekly Washington DC farmers' markets

\section{Dickinson College Organic Garden}

Intern

Carlisle, PA, USA (June 2003-May 2006)

- Trained new interns and volunteers in garden and greenhouse management

- Prepared annual planting calendars

- Conducted on-farm research on plant hormones in conjunction with biology department

- Managed Saturday markets and harvests for college cafeteria

- Organized local food promotional events on campus and within community

- Coordinated farm-to-food bank produce donations and distributions in low-income communities

\section{SKILLS}

- Languages (spoken and written): English (native); Spanish (advanced)

- Proficient in the use of Microsoft Office, Internet

- Proficient in the use of regression software (R studio), optimization software (Lindo, Excel Solver) 